Review

\title{
Novel Diagnostic Biomarkers in Colorectal Cancer
}

\author{
Aneta L. Zygulska ${ }^{1, *(D)}$ and Piotr Pierzchalski ${ }^{2}$
}

1 Department of Oncology, University Hospital, 2nd Jakubowski St., 30-688 Krakow, Poland

2 Department of Medical Physiology, Faculty of Health Science, Jagiellonian University Medical College, Michałowskiego 12 St., 31-126 Krakow, Poland; piotr.pierzchalski@uj.edu.pl

* Correspondence: zygulska@poczta.onet.pl

check for updates

Citation: Zygulska, A.L. Pierzchalski, P. Novel Diagnostic Biomarkers in Colorectal Cancer. Int. J. Mol. Sci. 2022, 23, 852. https:// doi.org/10.3390/ijms23020852

Academic Editors: Hidekazu Suzuki, Wojciech P. Polkowski and Agnieszka Mądro

Received: 5 December 2021

Accepted: 3 January 2022

Published: 13 January 2022

Publisher's Note: MDPI stays neutral with regard to jurisdictional claims in published maps and institutional affiliations.

Copyright: (C) 2022 by the authors. Licensee MDPI, Basel, Switzerland. This article is an open access article distributed under the terms and conditions of the Creative Commons Attribution (CC BY) license (https:// creativecommons.org/licenses/by/ $4.0 /)$.

\begin{abstract}
Colorectal cancer (CRC) is still a leading cause of cancer death worldwide. Less than half of cases are diagnosed when the cancer is locally advanced. CRC is a heterogenous disease associated with a number of genetic or somatic mutations. Diagnostic markers are used for risk stratification and early detection, which might prolong overall survival. Nowadays, the widespread use of semi-invasive endoscopic methods and feacal blood tests characterised by suboptimal accuracy of diagnostic results has led to the detection of cases at later stages. New molecular noninvasive tests based on the detection of CRC alterations seem to be more sensitive and specific then the current methods. Therefore, research aiming at identifying molecular markers, such as DNA, RNA and proteins, would improve survival rates and contribute to the development of personalized medicine. The identification of "ideal" diagnostic biomarkers, having high sensitivity and specificity, being safe, cheap and easy to measure, remains a challenge. The purpose of this review is to discuss recent advances in novel diagnostic biomarkers for tumor tissue, blood and stool samples in CRC patients.
\end{abstract}

Keywords: diagnostic biomarkers; colorectal cancer; early detection

\section{Introduction}

Colorectal cancer (CRC) is one of the most prevalent and incident cancers worldwide, as well as a significant cause of mortality. If colorectal cancer is detected in early stage, it is curable. Therefore, early detection can reduce mortality of colorectal cancer.

Colonoscopy has been well established as the gold standard of colorectal cancer screening with high sensitivity and specificity. However, it is costly in terms of money and manpower, requiring experienced endoscopists and patient adherence. The development of advanced molecular techniques comes with aid in detection and treatment of colorectal cancer. Currently, proteins, DNA (detection of mutations and methylation markers), RNA (mainly microRNAs), volatile organic compounds, changes and shifts in gut microbiome composition are the categories of colorectal biomarkers that have been explored [1,2].

Depending on the biological origin of material or the type of tissue being tested, we can distinguish biomarkers from the blood and stool.

Nowadays, colorectal mucus, urine, saliva and exhaled air are sources of additional diagnostic options/biomarkers [1].

The purpose of this review is to discuss recent advances in novel diagnostic biomarkers for tumor tissue, blood and stool samples in CRC patients.

\section{Blood Biomarkers}

In cancer diagnostics, biomarkers might be different types of circulating biochemical molecules, such as proteins, tumor DNA, tumor-derived cells and miRNA in the blood, all of which are frequently used in CRC diagnostics.

These biomarkers are detected in blood-based protein quantification tests or with immunohistochemistry [3,4]. Locally advanced malignant lesions enhance the level of circulating nucleic acids by up to 15 -fold, the concentration in patients with metastatic 
cancers reaching up to $500 \mathrm{ng} / \mathrm{mL}$ [3]. The ease with which blood can be collected or donated means that the detection of blood-based biomarkers could be a practical screening tool for CRC.

Genetic anomalies occur in a large fraction of sporadic non-hereditary cancers in the early stages of tumorogenesis. Large numbers of cells carrying these anomalies are shed from the developing tumor and can be found in biological effluents, mainly in stools, serum and urine as cell-free nucleid acids. The genetic anomalies can be easily identified by quick, non-invasive, relatively inexpensive molecular biomarkers with higher sensitivity and specificity than the feacal occult blood test (FOBT) or faecal immunochemical test (FIT) [5].

\subsection{Liquid Biopsy}

Liquid biopsy detects circulating tumor cells from any bodily fluid, including peripheral blood, urine and cerebrospinal fluid, ascites, pleural effusion, etc., and includes a genomic or proteomic assessment. It is a quick, easy and low-budget method with minimal invasiveness, making it widely accepted by patients, without major side effects [5-12].

Liquid biopsy (using mainly peripheral blood) can be used as a screening method to detect early-stage CRC and minimal residual disease after surgery, or identify the molecular profile of $\mathrm{CRC}$, the risk of recurrence, therapeutic targets, mechanisms of drug resistance and can influence the course of therapy in early CRC patients. In addition, liquid biopsy testing might allow the assessment of prognostic and predictive biomarkers in metastatic CRC patients [8-11]. However, currently, the clinical utility of liquid biopsies in CRC is limited. There is a need for better standardization and validation of liquid biopsy assessment [10].

Recent studies using liquid biopsy biomarkers in screening/diagnostics of CRC are collected in Table 1. 
Table 1. According to Vacante in modification: screening/diagnostics liquid biopsy biomarkers in CRC [10].

\begin{tabular}{|c|c|c|c|c|}
\hline Author/Year & $\begin{array}{l}\text { Detection Method/ } \\
\text { Biomarkers }\end{array}$ & Sensitivity [\%] & Specificity [\%] & $\begin{array}{l}\text { HR/OS/ } \\
p \text { Value }\end{array}$ \\
\hline Tsai/2019 [13] & $\begin{array}{l}\text { CellMax biomimetic platform } \\
\text { (CMx)/CTC }\end{array}$ & $\begin{array}{c}\text { Precancerous lesions: } 76.6 \\
\text { CRC: Sn } 86.9\end{array}$ & $\begin{array}{c}\text { Precancerous lesions: } 97.3 \\
\text { CRC: Sp } 97.3\end{array}$ & \\
\hline $\begin{array}{c}\text { Flamini/2006 } \\
{[14]}\end{array}$ & $\mathrm{qPCR} / \mathrm{ctDNA}$ & $\begin{array}{c}\text { ctDNA alone: } 81.3 \text { ctDNA + CEA: } \\
84.0\end{array}$ & ctDNA alone: 73.3 ctDNA + CEA: Sp 88.0 & \\
\hline Sun/2019 [15] & $\begin{array}{c}\text { Epigenomics AG for Epi proColon } \\
2.0 / \text { mSEPT9 DNA }\end{array}$ & $\begin{array}{c}\text { Precancarous lesions: } 17.1 \\
\text { CRC: Sn } 73.0\end{array}$ & $\begin{array}{c}\text { Precancerous lesions: } 94.5 \\
\text { CRC: } 94.5\end{array}$ & \\
\hline Wang/2017 [17] & $\begin{array}{c}\text { real-time PCR/ } \\
\text { Serum miR-31, miR-141, miR-224-3p, } \\
\text { miR-576-5p, and miR-4669 }\end{array}$ & & $\begin{array}{c}\text { AUC }=0.995 \text { (microarrays) } \text { AUC }=0.964 \\
\quad \text { (double-blind validation test) }\end{array}$ & \\
\hline Koga/2013 [18] & $\begin{array}{l}\text { real-time RT-PCR/ } \\
\text { fecal miR-106a }\end{array}$ & $\begin{array}{c}\text { FmiRT: } 34.2 \\
\text { iFOBT + FmiRT: } 70.9\end{array}$ & $\begin{array}{c}\text { FmiRT: } 97.2 . \\
\text { iFOBT + FmiRT: } 96.3\end{array}$ & \\
\hline Yan/2018 [20] & qRT-PCR*/exosomal miR-6803-5p & & & $\begin{array}{c}\text { OS: HR } 2.93 \text { (95\% CI 1.35-6.37, } \\
p<0.007) \text { DFS: HR } 3.26(95 \% \text { CI } \\
1.56-6.81, p<0.002) \text { AUC }=0.7399\end{array}$ \\
\hline Peng/2018 [21] & $\begin{array}{l}\text { real-time } \mathrm{qPCR} * / \\
\text { exosomal miR-548c-5p }\end{array}$ & & & $\begin{array}{c}\text { OS: HR } 3.40 \text { (95\% CI 1.02-11.27, } \\
p=0.046)\end{array}$ \\
\hline Liu/2016 [22] & $\begin{array}{c}\text { qRT-PCR */ } \\
\text { exosomal lncRNA CRNDE-h }\end{array}$ & 70.3 & 94.4 & \\
\hline
\end{tabular}


Table 1. Cont.

\begin{tabular}{|c|c|c|c|c|}
\hline Author/Year & $\begin{array}{l}\text { Detection Method/ } \\
\text { Biomarkers }\end{array}$ & Sensitivity [\%] & Specificity [\%] & $\begin{array}{l}\text { HR/OS/ } \\
p \text { Value }\end{array}$ \\
\hline Liu/2018 [23] & $\begin{array}{c}\text { qRT-PCR */ } \\
\text { exosomal miR-27a and miR-130a }\end{array}$ & $\begin{array}{c}\text { miR-27a: } \text { AUC }=0.773 \\
75 \text { in the training phase, } \\
\text { AUC }=0.82 \\
80.0 \text { in the validation phase, } \\
\text { AUC }=0.746 \\
80.0 \text { in the external validation phase } \\
\text { miR-130a: } \text { AUC }=0.742 \\
82.5 \text { in the training phase, } \\
\text { AUC }=0.787 \\
70.0 \text { in the validation phase, } \\
\text { AUC }=0.697 \text { 70.0 in the external validation } \\
\text { phase } \\
\text { miR-27a }+ \text { miR-130a: } \\
\text { training phase AUC }=0.846 \\
82.5, \\
\text { validation phase AUC }=0.898,80.0 \text { and } \\
\text { external validation phase AUC }=0.80180 .0\end{array}$ & $\begin{array}{c}\text { miR-27a: AUC }=0.773 \\
77.5 \text { in the training phase, } \mathrm{AUC}=0.82 \\
77.5 \text { in the validation phase, and AUC }=0.746 \\
77.5 \text { in the external validation phase } \\
\text { miR-130a: } \mathrm{AUC}=0.742 \\
62.5 \text { in the training phase, } \mathrm{AUC}=0.787 \\
80.0 \text { in the validation phase, } \mathrm{AUC}=0.697 \\
80.0 \text { in the external validation phase } \\
\text { miR-27a + miR-130a: training phase AUC }=0.846 \\
75, \text { validation phase } \\
\text { AUC }=0.898 \\
90.0 \\
90.0\end{array}$ & \\
\hline
\end{tabular}

${ }^{*}$ qRT-PCR quantitative reverse-transcription polymerase chain reaction. 


\subsection{Circulating Tumor Cells (CTC)}

CTCs are epithelial cancer cells from the primary tumor or metastases which gain access to the circulatory system and are detectable in peripheral blood [6,11]. They could be used as biomarkers to detect CRC or to provide information about mechanisms concerning dissemination and enable decisions about therapy. Nowadays the widely used gold standard and still only FDA-approved method for CTC detection is a highly sensitive assay combining immunomagnetic enrichment with multiparameter flow cytometric and immunocytochemical analysis (the CellSearch System) [24]. However, CTC estimation has some limitations, e.g., blood concentration of CTCs is extremely low, which makes this method unreliable as a diagnostic tool [25]. The number of circulating CTCs ranges from 1-10 cells per $10 \mathrm{~mL}$ blood and can be even lower in early-stage cancers [26]. In order to enrich CTCs from whole blood, microfabricated trapping chambers are put in microfluidic chip devices. The CTCs are isolated based on differences in size and shape between tumour and normal blood cells [27]. The results require further validation studies. The prognostic value of CTCs in CRC has been proven but their use in screening still remains controversial [9]. On the other hand, Tsai et al. reported an overall accuracy of $88 \%$ for all CRC stages, including precancerous lesions using a new CTC assay [13].

\subsection{Circulating Tumor DNA (ctDNA)}

While cell-free DNA (cfDNA) was first reported in the nineteen-forties, when noncell-bound nucleic acids were detected in the blood of cancer patients, the use of cfDNA as a diagnostic biomarker in daily practice started in the twenty-first century [28]. In many studies, high levels of cfDNA have been described in cancer patients. cfDNA fragments measure between 180 and 200 base pairs and mainly derive from apoptotic or necrotic tumor cells [29-32]. They can also originate from living tumor cells and circulating tumor cells.

Caspases are cysteine proteases belonging to a large family which includes serine, aspartic acid and metalloproteases. Proteases may induce the progression of neoplastic disease as they degrade the extracellular matrix and contribute to the invasion of tumor cells into adjacent normal tissue [33]. The deregulation of caspases leads to the release of DNA or nucleosomes into the blood circulation [34,35].

cfDNA contains tumor-specific genomic alterations, such as mutations, methylation, loss of heterozygosity and microsatellite instabilities $[36,37]$. Their half-life in the circulation ranges from $16 \mathrm{~min}$ to $2.5 \mathrm{~h}$ [38]. Indeed, the overall quantity of cfDNA is 24-fold higher in the serum than in plasma, but plasma samples are preferable for ctDNA analyses [39,40].

Besides neoplastic processes, cfDNA concentrations are increased in such diseases as acute brain injury, acute ischemic stroke, infection and even after organ transplantation or incremental exercise [41-45].

Genotyping ctDNA in the blood to determine a tumor profile seems to be a good diagnostic approach. The ctDNA assay is a quick, easy, minimally invasive method, enabling a comprehensive tissue profile. However, limited evidence for treatment selection in advanced cancer and low correlation with histology or cellular phenotype are the main disadvantages of this method [46].

Nowadays, there are many conventional and nanomaterial-based methods for the detection of ctDNA, such as next-generation sequencing (NGS), the amplification refractory mutation system (ARMS), peptide nucleic acid clamping polymerase chain reaction (PNA-PCR), droplet digital polymerase chain reaction (ddPCR), PCR products analyzed by surface-enhanced Raman spectroscopy (SERS), electrochemical DNA biosensors (the means of detection based on generated electronic signals), peptide nucleic acid clamping asymmetric polymerase chain reaction and liquidchip (PAPL), ddPCR analysis based on microfluidic devices (IC3D ddPCR), BEAMing (beads, emulsion, amplification, magnetics) and $\mathrm{Fe}-\mathrm{Au}$ nanoparticle-coupling strategy (a means of hybridization-based detection) [47].

ctDNA has been widely evaluated as a novel biomarker for liquid biopsy in colorectal cancer diagnosis, prognosis and monitoring of response to treatment. Liquid biopsy based on ctDNA detection is a very sensitive test. Bettegowda et al. demonstrated that the 
sensitivity of ctDNA for revealing clinically relevant KRAS gene mutations was $87.2 \%$ and its specificity was $99.2 \%$ in a group of 206 metastatic colorectal cancer patients [48].

\subsection{Circulating MicroRNA (c-miRNA)}

MicroRNA, a subclass of non-coding RNAs, was first discovered and characterised in the nineteen-nineties in Caenorhabditis elegans [49]. Interestingly, more than 38,500 human miRNAs have been described since then [50]. Moreover, circulating miRNA has played a role in diagnostics since the twenty-first century.

MicroRNAs participate in proliferation, migration, differentiation, hematopoiesis, cell cycle regulation and stemness [51]. Dysregulation of miRNA's function is a trigger of numerous diseases, e.g., cancer.

MicroRNAs arise from intergenic, exonic and intronic sequences from the DICERdependent pathway in the nucleus [52].

Initially, RNA polymerase II (POLR2) or RNA polymerase III (POLR3) take part in miRNA formation $[53,54]$. Primary transcripts (pri-miRNAs) several kilobases in length, which are $5^{\prime}$ capped and $3^{\prime}$ polyadenylated, are performed in the first stage of biogenesis. Subsequently, pri-miRNA is transformed into pre-miRNA by the microprocessor complex consisting of ribonuclease (RNase) III enzyme DROSHA and its cofactor [55]. The premiRNA is transported to the cytoplasm via Exportin-5 with Ran-GTP. The pre-miRNA is digested with the RNase III enzyme DICER and mature miRNA is produced [56]. There are alternative methods of miRNA maturation, such as DICER-independent biogenesis, DROSHA/DGCR8-independent biogenesis, the endogenous siRNA strategy and small nucleolar RNA-derived miRNAs [57-60].

miRNAs interact with the RNA-induced silencing complex (RISC) to bind to the $3^{\prime}$ untranslated region of mRNA molecules and regulate transcription and mRNA stability [61,62].

Circulating miRNAs play a role in communication between cells and influence gene expression in distant and adjacent target cells [63]. miRNAs are involved in post-transcriptional regulation of more than $60 \%$ of all protein-coding genes [64].

Circulating miRNAs is transferred associated mainly to exosomes or forming complexes with proteins such as Ago2 (Argonaute) [6].

miRNA concentrations are higher in plasma than in serum. Only extremely up- or downregulated miRNAs seems to be suitable to serve as clinical biomarkers [65]. In comparison to normal mucosa, close to two-thirds of miRNAs were downregulated in CRC [66]. Bartley et al. described 230 miRNAs that were differentially expressed in the four-stage transformation from nonneoplastic mucosa of the large bowel through low-grade dysplasia and high-grade dysplasia in adenoma to colorectal adenocarcinoma [67].

Dysregulation of miRNAs occurs frequently in adenoma and CRC. Therefore, they are a potential source of optimal biomarkers. The most common dysregulations are collected in Table 2.

Table 2. According to Liu and Li dysregulated miRNAs in colorectal adenoma and carcinoma $[66,68]$.

\begin{tabular}{ccc}
\hline Author/Year & Change & miRNA \\
\hline Yin/2016 [69] & upregulation & miR-18a, miR-18b, miR-31, miR-142-5p, miR-212 \\
Uratani/2016 [70] & upregulation & miRNA-21, miRNA-92a, miRNA-135b \\
Imaoka/2016 [71] & upregulation & miRNA-1290 \\
Ho/2015 [72] & upregulation & miRNA-486 \\
De Groen/2015 [73] & upregulation & miRNA-15a, miRNA-17. miRNA-20a \\
Wu CW/2014 [74] & upregulation & miRNA-31, miRNA-135 b \\
Wu CW /2012 [75] & upregulation & miRNA-92a \\
Tsikitis/201 [76] & downregulation & miRNA-143, miRNA-145, miRNA -30a \\
Tadano/2016 [77] & downregulation & miRNA-320 family \\
Yin/2016 [69] & downregulation & miR-145, miR-451, miR-638 \\
Chen T/2017 [78] & downregulation & miRNA-137 \\
\hline
\end{tabular}


Table 2. Cont.

\begin{tabular}{clc}
\hline Author/Year & Change & miRNA \\
\hline Ho/2015 [72] & downregulation & miRNA-30 \\
Hibino/2015 [79] & downregulation & miRNA148a \\
Fang/2015 [80] & downregulation & miRNA24, miRNA-320a, miRNA-423-5p \\
\hline
\end{tabular}

Microarrays are the technology that make it possible to test simultaneously thousands of genes for differential expression. This technique is used to estimate miRNA profile changes in colorectal adenomas and CRC. Storage conditions of samples are very important: miRNA levels are stable at room temperature for at least $24 \mathrm{~h}$ in whole blood samples, while miRNAs are degraded at room temperature in serum samples; therefore, serum miRNAs should be stored for up to $72 \mathrm{~h}$, refrigerated at $4{ }^{\circ} \mathrm{C}$ or frozen at $-20^{\circ} \mathrm{C}$, because of the reduction of RNase activity at low temperatures [81,82].

RT-qPCR, digital PCR (ddPCR), hybridization-based techniques (e.g., microarrays, NanoString) and next generation sequence (NGS) are methods used to profile miRNAs [83].

It is necessary to establish clinically valid diagnostic techniques (RNA extraction, reverse transcription, qPCR analysis) using these markers as well as their optimisation and standardisation $[6,65]$.

Nowadays, single miRNA markers of CRC, as well as combinations of miRNA markers detectable in plasma or serum, were also tested as diagnostic panels. Unfortunately, most of these studies gave modest or inconsistent results due to the fact that single miRNA has limitations in terms of low sensitivity and specificity. The levels of single miRNA molecules in CRC patients and healthy subjects frequently overlapped. Furthermore, the method of sampling should be able to distinguish patients with cancer from healthy individuals [84].

It is necessary to control hemolysis in samples in a preanalytical phase because hemolysis may change levels of circulating miRNA in samples due to the rupture of erythrocytes containing miRNAs [85]. There is still a lack of consensus on an adequate endogenous normalizer to quantify circulating miRNA expression in CRC [6].

Optimal conditions for processing blood specimens for miRNA measurement need to be established (e.g., in order to avoid the contamination of platelets in samples) [86]. Moreover, it is difficult to determine whether miRNA in the circulation is cancer-specific or co-morbidities specific [87].

MicroRNA variants investigated as potential diagnostic CRC markers are listed in Table 3.

Table 3. According to Loktionov in modification miRNA biomarkers used for CRC detection [1].

\begin{tabular}{|c|c|c|c|c|}
\hline Author/Year & Sample Type & $\begin{array}{c}\text { Biomarker/Detection } \\
\text { Method }\end{array}$ & Sensitivity [\%] & Specificity [\%] \\
\hline Kanaan/2013 [88] & plasma & $\begin{array}{c}\text { miR-532-3p, } \\
\text { miR-331, } \\
\text { miR-195, } \\
\text { miR-17, } \\
\text { miR-142-3p, } \\
\text { miR-15b, } \\
\text { miR-532, } \\
\text { miR-652 }\end{array}$ & $\begin{array}{l}\text { polyps from controls [area under } \\
\text { curve (AUC) }=0.868(95 \% \\
\text { confidence interval [CI]: } \\
0.76-0.98)] \text {. } \\
\text { stage IV CRC from controls with } \\
\text { an [AUC }=0.896 \text { ( } 95 \% \text { CI: } \\
0.78-1.0)] . \text { Receiver-operating- } \\
\text { characteristic curves of miRNA } \\
\text { panels for all CRC versus } \\
\text { controls and polyps versus all } \\
\text { CRC AUC values of } 0.829(95 \% \\
\text { CI: } 0.73-0.93) \text { and } 0.856(95 \% \text { CI: } \\
0.75-0.97)\end{array}$ & \\
\hline
\end{tabular}


Table 3. Cont.

\begin{tabular}{|c|c|c|c|c|}
\hline Author/Year & Sample Type & $\begin{array}{c}\text { Biomarker/Detection } \\
\text { Method }\end{array}$ & Sensitivity [\%] & Specificity [\%] \\
\hline Giraldez/2013 [89] & plasma & $\begin{array}{c}\text { miRNA-18a, miRNA-19a, } \\
\text { miRNA-19b, miRNA-15b, } \\
\text { miRNA-29a, miRNA-335/ } \\
\text { up-regulated }\end{array}$ & $\begin{array}{l}\text { areas under the receiver } \\
\text { operating characteristic curve } \\
\text { (AUROC) ranging from } 0.80 \\
(95 \% \text { confidence interval }[\mathrm{CI}] \\
0.71-0.89) \text { to } 0.70(95 \% \mathrm{CI}, \\
0.59-0.80)\end{array}$ & \\
\hline Wang/2014 [90] & serum & $\begin{array}{c}\text { miRNA-21, let-7g, } \\
\text { miRNA-31, miRNA-92a, } \\
\text { miRNA-181b, miRNA-203/ } \\
\text { up-regulated }\end{array}$ & 93 & 91 \\
\hline Slaby/2016 [91] & plasma & $\begin{array}{l}\text { miR-20a/upregulated } \\
\text { miR-155/upregulated }\end{array}$ & $\begin{array}{c}46 \\
58.2\end{array}$ & $\begin{array}{c}73.4 \\
95\end{array}$ \\
\hline $\begin{array}{l}\text { Slaby/2016 [91] } \\
\text { Carter/2017 [92] } \\
\text { Chen/2019 [93] } \\
\text { Sabry/2019 [94] }\end{array}$ & plasma/serum & miR-21/upregulated & $65-91.4$ & 74.4-95 \\
\hline Carter/2017 [92] & plasma & $\begin{array}{c}\text { miR-24/downregulated } \\
\text { miR-29a/upregulated } \\
\text { miR-92/upregulated } \\
\text { miR-29b/downregulated } \\
\text { miR-106a/upregulated } \\
\text { miR-194/downregulated } \\
\text { miR-200c/upregulated } \\
\text { miR-320a/downregulated } \\
\text { miR-372/upregulated } \\
\text { miR-375/downregulated } \\
\text { miR-423-5p/downregulated } \\
\text { miR-601/downregulated } \\
\text { miR-760/downregulated }\end{array}$ & $\begin{array}{c}78.4 \\
69 \% \\
89 \% \\
61.4-77 \\
74 \\
72 \\
64.1 \\
92.8 \\
81.9 \\
76.9 \\
91.9 \\
69.2 \\
80\end{array}$ & $\begin{array}{c}83.8 \\
89.1 \\
70 \\
72.5-75 \\
44.4 \\
80 \\
73.3 \\
73.1 \\
73.3 \\
64.6 \\
70.8 \\
72.4 \\
72.4\end{array}$ \\
\hline $\begin{array}{l}\text { Slaby/2016 [91] } \\
\text { Carter/2017 [92] }\end{array}$ & plasma/serum & $\begin{array}{l}\text { miR-92a/upregulated } \\
\text { miR-96/upregulated } \\
\text { miR-221/upregulated }\end{array}$ & $\begin{array}{c}65.5-74 \\
65.4 \\
86\end{array}$ & $\begin{array}{c}71.2-82.5 \\
73.3 \\
41\end{array}$ \\
\hline $\mathrm{Ng} / 2017$ [95] & serum & miR-139-3p/downregulated & 96.6 & 97.8 \\
\hline Wang/2017 [96] & serum & miR-139a-5p/upregulated & 76.7 & 88 \\
\hline Liu/2018 [97] & plasma & miR-182/upregulated & 78 & 91 \\
\hline $\begin{array}{c}\text { Bilegsaikham } / 2018 \\
\text { [98] }\end{array}$ & serum & $\begin{array}{l}\text { miR-196b/upregulated } \\
\text { miR-338-5p/upregulated }\end{array}$ & $\begin{array}{c}63 \\
76.30 \\
\end{array}$ & $\begin{array}{c}87.4 \\
92.50\end{array}$ \\
\hline $\begin{array}{l}\text { Carter/2017 [92] } \\
\text { Sabry/2019 [94] }\end{array}$ & serum & miR-210/upregulated & $74.6-88.6$ & $73.5-90.10$ \\
\hline $\begin{array}{c}\text { Krawczyk/2017 } \\
\text { [99] }\end{array}$ & plasma & $\begin{array}{l}\text { miR-506/upregulated } \\
\text { miR-4316/upregulated }\end{array}$ & $\begin{array}{l}76.8 \\
76.8\end{array}$ & $\begin{array}{c}60.7 \\
75\end{array}$ \\
\hline Imaoka/2016 [71] & serum & miR-1290/upregulated & 70.1 & 91.2 \\
\hline $\begin{array}{c}\text { Nonaka/2015 } \\
{[100]}\end{array}$ & serum & $\begin{array}{l}\text { miR-103/upregulated } \\
\text { miR-720/upregulated }\end{array}$ & $\begin{array}{l}55.9 \\
58.3\end{array}$ & $\begin{array}{c}75 \\
56.3\end{array}$ \\
\hline $\begin{array}{c}\text { Sarlinova } / 2013 \\
\text { [101] }\end{array}$ & whole blood & $\begin{array}{c}\text { miR-21/upregulated } \\
\text { miR-221/upregulated } \\
\text { miR-150/downregulated }\end{array}$ & 80 (three markers) & $\begin{array}{l}74 \text { (three } \\
\text { markers) }\end{array}$ \\
\hline Chang/2016 [102] & plasma & $\begin{array}{l}\text { miR-92a/upregulated } \\
\text { miR-223/upregulated }\end{array}$ & $\begin{array}{c}0.75 \\
0.707 \text { (AUC values) }\end{array}$ & \\
\hline
\end{tabular}


Table 3. Cont.

\begin{tabular}{|c|c|c|c|c|}
\hline Author/Year & Sample Type & $\begin{array}{c}\text { Biomarker/Detection } \\
\text { Method }\end{array}$ & Sensitivity [\%] & Specificity [\%] \\
\hline $\begin{array}{l}\text { Slaby /2016 [91] } \\
\text { Carter/2017 [92] }\end{array}$ & serum & $\begin{array}{l}\text { miR-21 and miR-92a/both } \\
\text { upregulated }\end{array}$ & 68 (whole panel) & 91.2 (whole panel) \\
\hline $\begin{array}{l}\text { Slaby / } 2016[91] \\
\text { Carter/2017 [92] }\end{array}$ & plasma & $\begin{array}{l}\text { miR-29a and miR-92a/both } \\
\text { upregulated }\end{array}$ & 83 (whole panel) & 84.7 (whole panel) \\
\hline $\begin{array}{l}\text { Nikolaou/2018 } \\
\text { [103] } \\
\text { Carter / 2017 [92] }\end{array}$ & plasma & $\begin{array}{l}\text { miR-200c and miR- } \\
\text { 18a/both upregulated }\end{array}$ & 84.6 (whole panel) & 75.6 (whole panel) \\
\hline Slaby/2016 [91] & plasma & $\begin{array}{c}\text { miR-223 and miR- } \\
\text { 92a/both upregulated }\end{array}$ & 76 (whole panel) & 71 (whole panel) \\
\hline Liu/2019 [104] & plasma & $\begin{array}{l}\text { miR-320d/downregulated } \\
\text { miR-1290/upregulated }\end{array}$ & 81.2 (whole panel) & 90.7 (whole panel) \\
\hline Carter/2017 [92] & plasma & $\begin{array}{l}\text { miR-431 and miR- } \\
139-\mathrm{p} 3 / \\
\text { both upregulated }\end{array}$ & 91 (whole panel) & 57 (whole panel) \\
\hline $\begin{array}{l}\text { Slaby /2016 [91] } \\
\text { Carter/2017 [92] }\end{array}$ & plasma & $\begin{array}{l}\text { miR-601 and miR-760/both } \\
\text { downregulated }\end{array}$ & 83.3 (whole panel) & 69.1 (whole panel) \\
\hline Carter/2017 [92] & plasma & $\begin{array}{l}\text { miR-19a, miR-19b and } \\
\text { miR-15b/all upregulated }\end{array}$ & 78.6 (whole panel) & 79.2 (whole panel) \\
\hline $\begin{array}{l}\text { Nikolaou/2018 } \\
\text { [103] } \\
\text { Carter/2017 [92] }\end{array}$ & plasma & $\begin{array}{c}\text { miR-24, miR-320a and } \\
\text { miR-423-5p/ } \\
\text { all downregulated }\end{array}$ & 92.8 (whole panel) & 70.8 (whole panel) \\
\hline $\begin{array}{l}\text { Slaby / } 2016[91] \\
\text { Carter/2017 [92] }\end{array}$ & serum & $\begin{array}{l}\text { miR-145/downregulated, } \\
\text { miR-106a and } \\
\text { miR-17-3p/upregulated }\end{array}$ & 78.5 (whole panel) & 82.8 (whole panel) \\
\hline $\begin{array}{l}\text { Slaby/2016 [91] } \\
\text { Carter/2017 [92] }\end{array}$ & plasma & $\begin{array}{c}\text { miR-409-3p/upregulated } \\
\text { miR-7 and miR-93/ } \\
\text { downregulated }\end{array}$ & 82 (whole panel) & 89 (whole panel) \\
\hline $\begin{array}{l}\text { Wikberg/2018 } \\
{[105]}\end{array}$ & plasma & $\begin{array}{c}\text { miR-18a, miR-21, miR-22 and } \\
\text { miR-25/ } \\
\text { all upregulated }\end{array}$ & 67 (whole panel) & 90 (whole panel) \\
\hline $\begin{array}{c}\text { Nikolaou/2018 } \\
\text { [103] }\end{array}$ & serum & $\begin{array}{l}\text { miR-23a-3p, miR-27a-3p, } \\
\text { miR-142-5p and } \\
\text { miR-376c-3p/all upregulated }\end{array}$ & 89 (whole panel) & 81 (whole panel) \\
\hline Carter/2017 [92] & plasma & $\begin{array}{l}\text { miR-29a, miR-92a/ } \\
\text { upregulated, } \\
\text { miR-601, miR-760/ } \\
\text { downregulated }\end{array}$ & 83.3 (whole panel) & 93.1 (whole panel) \\
\hline Chen/2019 [93] & serum & $\begin{array}{c}\text { miR-21, } \mathrm{miR}-29, \text { miR-92, } \\
\text { miR-125, miR-223/all } \\
\text { upregulated }\end{array}$ & 84.7 (whole panel) & 98.7 (whole panel) \\
\hline $\begin{array}{c}\text { Herreros- } \\
\text { Villanueva/2019 } \\
\text { [106] }\end{array}$ & plasma & $\begin{array}{c}\text { miR-19a, miR-19b, miR-15b, } \\
\text { miR-29a, } \\
\text { miR-335, miR-18a/ } \\
\text { all upregulated }\end{array}$ & 91 (whole panel) & 90 (whole panel) \\
\hline Slaby /2016 [91] & plasma & $\begin{array}{c}\text { miR-21, let-7g/ } \\
\text { upregulated, } \\
\text { miR-31, mir-92a, } \\
\text { miR-181b, miR-203/ } \\
\text { downregulated }\end{array}$ & 96 (whole panel) & 81 (whole panel) \\
\hline
\end{tabular}


Table 3. Cont.

\begin{tabular}{|c|c|c|c|c|}
\hline Author/Year & Sample Type & $\begin{array}{c}\text { Biomarker/Detection } \\
\text { Method }\end{array}$ & Sensitivity [\%] & Specificity [\%] \\
\hline Zhang/2019 [107] & plasma & $\begin{array}{l}\text { miR-103a-3p, miR- } \\
\text { 127-3p, miR-151a-5p, } \\
\text { miR-17-5p, miR- } \\
\text { 181a-3p, miR-18a-5p, } \\
\text { miR-18b-5p/all } \\
\text { upregulated }\end{array}$ & 76.9 (whole panel) & $\begin{array}{l}86.7 \% \text { (whole } \\
\text { panel) }\end{array}$ \\
\hline $\mathrm{Liu} / 2018$ [23] & plasma & $\begin{array}{c}\text { exosomal miR-27a, } \\
\text { miR-130a/both upregulated }\end{array}$ & 82.5 (whole panel) & $\begin{array}{l}75 \text { (whole } \\
\text { panel) }\end{array}$ \\
\hline Tian/2019 [108] & plasma & hsa_circ_0004585/upregulated & $85.1 \%$ & $51.1 \%$ \\
\hline $\begin{array}{c}\text { Marcuello/2019 } \\
\text { [25] }\end{array}$ & plasma & $\begin{array}{c}\text { miR-15b-5p/upregulated } \\
\text { miR-18a-5p/upregulated } \\
\text { miR-29a-3p/upregulated } \\
\text { miR-335-5p/upregulated } \\
\text { miR-19a- } \\
\text { 3p/upregulatedmiR-19b- } \\
\text { 3p/upregulated }\end{array}$ & $\begin{array}{l}81 \text { (whole panel with fecal } \\
\text { hemoglobin) }\end{array}$ & $\begin{array}{l}78 \text { (whole } \\
\text { panel with } \\
\text { fecal } \\
\text { hemoglobin) }\end{array}$ \\
\hline Karimi/2019 [109] & plasma & $\begin{array}{l}\text { miR-23a/upregulated } \\
\text { miR-301a/upregulated }\end{array}$ & $\begin{array}{c}0.89 \\
0.84 \\
\text { (AUC values) }\end{array}$ & \\
\hline Tan/2019 [110] & plasma & $\begin{array}{l}\text { miR-144-3p, miR-425-5p, and } \\
\text { miR-1260b }\end{array}$ & 93.8 (whole panel) & $\begin{array}{l}91.3 \text { (whole } \\
\text { panel) }\end{array}$ \\
\hline $\begin{array}{c}\text { Maminezdah } / 2020 \\
{[111]}\end{array}$ & serum & $\begin{array}{c}\text { miR-143/downregulated } \\
\text { miR-145/downregulated } \\
\text { miR-19a/upregulated } \\
\text { miR-20a/upregulated } \\
\text { miR-150/upregulated } \\
\text { let-7a/upregulated }\end{array}$ & $\begin{array}{c}0.76 \\
0.78 \\
0.87 \\
0.83 \\
0.75 \\
0.71 \\
\text { (area under the ROC curves) }\end{array}$ & \\
\hline $\mathrm{Liu} / 2020$ [112] & plasma & $\begin{array}{l}\text { exosomal miR-139-3p/ } \\
\text { downregulated } \\
\text { miR-139-3p and CEA }\end{array}$ & $\begin{array}{l}0.726 \text { (AUC value) } \\
0.868 \text { (AUC value) }\end{array}$ & \\
\hline Jin/2020 [113] & serum & $\begin{array}{l}\mathrm{miR}-4516 / \text { upregulated } \\
\text { miR-21-5p/downregulated } \\
\text { both of them }\end{array}$ & $\begin{array}{c}94.4 \\
90.63 \\
92.11\end{array}$ & $\begin{array}{l}89.8 \\
86.2 \\
87.9\end{array}$ \\
\hline
\end{tabular}

\subsection{Sept 9 Methylation}

Promoter CpG island methylation occurs more frequently than genetic mutation in cases of CRC. Hypermethylation contributes to carcinogenesis mostly by inducing transcriptional silencing or downregulation of tumour suppressor genes. Over 600 hypermethylated genes have been identified so far. Better understanding of epigenetics and technological progress enables the translation of laboratory research into daily clinical practice tools [114].

In humans, there are 13 genes (SEPT1-SEPT13) in the SEPT gene family. The SEPT9 gene is located on the human chromosome 17q25 [115].

The best-known blood marker is SEPT9 methylated DNA. The detection rate of this method ranges from $57 \%$ to $64 \%$ in patients with CRC stages 0-I [7]. The combination of the detection of SEPT9 promotor region methylation in plasma with FIT increased the sensitivity to $94 \%$ [103]. A meta-analysis published in 2017 including 25 research articles found that the SEPT9 assay is only superior to the FIT in the symptomatic population [116]. The next meta-analysis confirmed that the rate of $\mathrm{mSEPT9}$ positivity was higher in advanced CRC cases compared with early-stage CRC cases and was higher in CRC than in adenomas. Diagnostic sensitivity was not correlated with cancer localization (left-sided versus right- 
sided) but with the race of tested individuals (being superior among Asian compared with Caucasian populations) [117]. The updated meta-analysis published in 2020 revealed that the SEPT9 assay has a sensitivity of $69 \%$ and a specificity of $92 \%$ for CRC diagnostics.

This test exhibited a poorer performance in detecting precancerous lesions (advanced adenomas and polyps) and is an expensive method [118].

In 2016 the FDA approved as a screening tool the Epi proColon Kit version 1.0 (which later was upgraded to version 2.0) that detects SEPT9 promotor region methylation in plasma-originated tumour DNA, which is considered to be a specific biomarker of early CRC stages $[119,120]$.

The SEPT9 methylation assay is a qualitative test, which can be interpreted as positive or negative according to the application of different algorithms. Positive test results can be defined by one positive count out of three PCRs ( $1 / 3$ algorithm), three positive counts out of three PCRs ( $3 / 3$ algorithm), two positive counts out of three PCRs ( $2 / 3$ algorithm) or one positive count out of one PCR (1/1 algorithm). Sensitivity increased with the decline in the required number of positive PCR reactions, while specificity increased with the rise in the required number of positive PCR reactions [121].

In the prospective PRESEPT (PRospective Evaluation of SEPT) study, the methylated SEPT9 assay demonstrated a sensitivity of $48 \%$ for CRC (for stage I, $35 \%$; II, $63 \%$; III, $46 \%$; and IV, $77 \%$ ) and a specificity of $92 \%$. Sensitivity was very low for advanced adenomas $(14.4 \%)$ and only slightly higher than the false positive rate for all subjects who did not have cancer [122].

The US Preventive Services Task Force and the American Chemical Society currently do not include the Epi proColon test in their CRC screening guidelines due to its lack of effectiveness in detecting important precancerous lesions [123]. (An update of screening guidelines is currently in progress.) Recent studies using the SEPT9 gene methylation assay in diagnostics of CRC are shown in Table 4.

Table 4. Sensitivity and specificity of the SEPT9 gene methylation assay for colorectal cancer detection.

\begin{tabular}{|c|c|c|c|c|}
\hline Author/Year & $\begin{array}{c}\text { CRC/Number of } \\
\text { Cases }\end{array}$ & Assay Used & Sensitivity [\%] & Specificity [\%] \\
\hline Grützmann/2008 [124] & $252 / 354$ & research assay & 72 & 90 \\
\hline Lofton-Day/2008 [125] & $150 / 350$ & research assay & 52 & 95 \\
\hline DeVos/2009 [126] & $97 / 172$ & mSEPT9 assay & 72 & 93 \\
\hline $\mathrm{He} / 2010$ [127] & 182 & research assay & 75 & 96.47 \\
\hline Tanzer/2010 [128] & $73 / 128$ & research assay & 73 & 91 \\
\hline Herbst/2011 [129] & $45 / 345$ & research assay & 46.6 & 81.3 \\
\hline Warren/2011 [130] & $50 / 144$ & Epi proColon 1.0 & 90 & 88.3 \\
\hline Toth/2012 [131] & $92 / 184$ & Epi proColon 2.0 & $\begin{array}{l}95.6 \\
793\end{array}$ & $\begin{array}{l}84.8 \\
989\end{array}$ \\
\hline Alquist/2012 [132] & $30 / 52$ & Epi proColon 1.0 & 39 & 79 \\
\hline Lee/2013 [133] & $101 / 197$ & $\begin{array}{l}\text { mS9 Colorectal Cancer } \\
\text { Assay System }\end{array}$ & 36.6 & 90.6 \\
\hline Church/2014 [122] & $53 / 1516$ & Epi proColon 1.0 & 48.2 & 91.5 \\
\hline Potter/2014 [134] & $44 / 1544$ & Epi proColon 1.0 & 68 & 80 \\
\hline $\mathrm{Su} / 2014$ [135] & $172 / 234$ & MSP-DHPLC & 88.4 & 93.5 \\
\hline Johnson/2014 [136] & $101 / 200$ & Epi proColon 1.0 & 73.3 & 81.5 \\
\hline Jin/2015 [137] & $135 / 341$ & Epi proColon 2.0 & 74.8 & 87.4 \\
\hline Kang/2014 [138] & $80 / 132$ & Epi proColon 2.0 & 79.5 & 98.1 \\
\hline Toth/2014 [139] & $34 / 84$ & Epi proColon 2.0 & 82.8 & 91.7 \\
\hline Song 2016 [121] & $369 / 1133$ & Epi proColon 2.0 & $58-82.4$ * & $82-98.8 *$ \\
\hline Ørntoft/2015 [140] & $150 / 150$ & Epi proColon 1.0 & 73 & 82 \\
\hline Behrouz Sharif/2016 [141] & $45 / 45$ & MS-HRM assay & 84.4 & 99 \\
\hline \multirow{2}{*}{$\mathrm{Wu} / 2016$ [142] } & \multirow{2}{*}{$291 / 1031$} & Epi proColon 2.0 & 73.0 & 97.5 \\
\hline & & new SEPT9 assay & 76.6 & 95.9 \\
\hline Nian/2016 [143] & $2975 / 6952$ & Epi proColon 2.0 & 71 & 92 \\
\hline
\end{tabular}


Table 4. Cont.

\begin{tabular}{ccccc}
\hline Author/Year & $\begin{array}{c}\text { CRC/Number of } \\
\text { Cases }\end{array}$ & Assay Used & Sensitivity [\%] & Specificity [\%] \\
\hline $\mathrm{Fu} / 2018[144]$ & $98 / 558$ & Epi proColon 2.0 & 61.22 & 93.7 \\
Xie/2018 [145] & $123 / 248$ & research assay & 61.8 & 89.6 \\
Arellano/2020 [146] & $10 / 10$ & Epi proColon 2.0 & 88.9 & 100 \\
Hariharan/2020 [118] & 7629 & mSEPT9 test & 69 & 92 \\
Liu/2020 [147] & $38 / 124$ & Epi proColon 2.0 & 85.6 & 90.1 \\
\hline
\end{tabular}

* using different algorithm.

\subsection{Long Non Coding RNA ( $\operatorname{lnc} R N A)$}

Within the last decade a number of researchers have demonstrated that long noncoding RNAs (lncRNAs) are stable in blood and have diagnostic potential [148-151]. Based on length, ncRNAs are divided into two classes: small non-coding RNAs, whose length is a maximum of 200 nucleotides (i.e., microRNAs (miRNAs), small interfering RNAs (siRNAs), PIWI-interacting RNAs (piRNAs)) [152,153]; and long non-coding RNAs (lncRNAs), which have 200 or more nucleotides and which influence cancer cells through mechanisms such as chromatin remodeling, chromatin interaction, competing endogenous RNAs and natural antisense transcripts [154]. IncRNAs can be found in different body fluids, such as blood, plasma/serum or urine, due to the fact that it can cross cell membranes [155]. They derive from both living cells in an active manner and apoptotic cells.

Many lncRNAs are associated with all stages of tumorigenesis and progression of CRC $[154,156]$. Their altered expression can influence several oncogenic signaling cascades, including the WNT/ $\beta$-catenin, PI3K/Akt, EGFR, NOTCH, mTOR and TP53 signaling pathways [157-159]. Interestingly, circulating RNA directly represents the expression level of certain genes, which could distinguish cancer patients and healthy subjects [160]. Moreover, circulating RNA are characterised by their relative resistance to degradation by RNase enzymes [161,162].

Apoptotic bodies, microvesicles and exosomes are extracellular phospholipid-enclosed vesicles which travel with lncRNAs in the blood. These extracellular vesicles are released by cells into their environment. Their function is to transfer DNA, RNA, lipids, proteins, glycans and metabolites among cells [163-165]. There are three subgroups of extracellular vesicles. Apoptotic bodies $50-500 \mathrm{~nm}$ in diameter are released from cells undergoing programmed cell death. Microvesicles $50-1000 \mathrm{~nm}$ in diameter are produced by cell membranes $[164,166]$. Exosomes have intracellular origins and are $30-150 \mathrm{~nm}$ in diameter [167]. Among the three types of extracellular vesicles, exosomes express the highest levels of long micro RNAs (lmiRNAs) and contribute to chemoresistance, immunomodulation and metastasis in various tumor types [148,168]. It is estimated that around $2 \times 10^{15}$ exosomes occur in the blood of healthy people. Exosome numbers can reach $4 \times 10^{15}$ in case of cancer $[169,170]$. The most commonly used method for separating and accumulating vesicles is ultracentrifugation. This method is time-consuming and requires large amounts of starting material and expensive equipment. The commercial kits for exosome isolation are not standardized and the purity of results is low [171].

Quantitative reverse-transcription polymerase chain reaction (qRT-PCR) is the most used method of identification of circulating miRNA due to its high sensitivity and specificity [172]. The data obtained with qRT-PCR requires a normalization process in order to avoid potential technical bias which can be caused by pre-analytical or technical factors arising from miRNA extraction through to the amplification process. Unfortunately, there are no known adequate endogenous control or housekeeping genes to normalize the expression of miRNAs in different plasma or serum samples in cases of CRC. Duran-Sanchez et al. demonstrated that detection of miR-1228-3p showed no significant differences between hemolytic and non-hemolytic serum samples. Validated miR-1228-3p seems to be an adequate endogenous control for circulating miRNA analysis in CRC and advanced adenoma liquid biopsies [173]. 
CCAT1 and HOTAIR were the first markers reported to have significantly elevated expression in the plasma of CRC patients compared to healthy subjects [174]. Many other circulating lncRNAs have been described as potential biomarkers for CRC detection (e.g., LOC285194, RP11-462C24.1 and Nbla12061, 91H, PVT-1 and MEG3, NEAT1 variant 1 and NEAT1 variant 2); they are presented in Table 5.

Table 5. According to Loktionov in modification: long non-coding RNA biomarkers used for CRC detection [1].

\begin{tabular}{|c|c|c|c|c|}
\hline Author/Year & Sample Type & Biomarker(S) & Sensitivity [\%] & Specificity $[\%]$ \\
\hline Zhao/2015 [174] & serum & CCAT1 and HOTAIR & 84.3 & 80.2 \\
\hline Wang/2016 [175] & serum & $\begin{array}{c}\text { LOC285194, RP11-462C24.1 and } \\
\text { Nbla12061 }\end{array}$ & 68.3 & 86.9 \\
\hline Dong/2016 [148] & serum & $\begin{array}{c}\text { BCAR4, } \\
\text { two mRNAs: } \\
\text { KRTAP5-4 and MAGEA3 }\end{array}$ & 93.6 & 85.7 \\
\hline Dai/2017 [176] & serum & BLACAT1 & 83.3 & 76.7 \\
\hline Barbagallo/2018 [177] & serum & UCA1 & 100 & 43 \\
\hline Liu/2019 [178] & plasma & $\begin{array}{l}\text { 91H, PVT-1 and } \\
\text { MEG3 }\end{array}$ & 82.8 & 78.6 \\
\hline Abedini/2019 [179] & plasma & ATB, CCAT1 & 82.0 & 75.0 \\
\hline Nikolaou/2019 [103] & whole blood & NEAT1 variant 1 & 69.0 & 79.0 \\
\hline Nikolaou/2019 [103] & whole blood & NEAT1 variant 2 & 70.0 & 96.0 \\
\hline
\end{tabular}

Meta-analyses have attempted to summarize the potential clinical usefulness of circulating miRNAs in early CRC detection [92,175,180-182]. It seems that the simultaneous detection of entire panels of RNAs instead of a single circulating lncRNA increases the sensitivity and specificity of this diagnostic tool.

\subsection{Insulin-like Growth Factor Binding Protein 2 (IGFBP-2)}

Various growth factors, e.g., insulin-like growth factors (IGF-1 and IGF-2), stimulate tumor growth and play a role as mitogens for colon mucosa [183-186]. IGFBP-2 is an extracellular protein binding insulin growth factor 2 (IGF-2) which participates in heat shock protein 27-mediated cancer progression and metastasis [187]. Both IGFBP-2 and IGFBP-1 participate in the regulation of cell proliferation, regulation of differentiation and apoptosis prevention. An increased level of IGFBP-2 in serum correlates with the presence of neoplastic alterations in the colon and concentrations of carcinoembryonic antigen (CEA) in colon cancer patients [188,189]. Therefore, assessment of IGFBP-2 levels has been suggested as a diagnostic parameter in the surveillance of patients with colorectal cancer. In turn, IGFBP-2 overabundance during colorectal carcinogenesis reduces tumor growth by the inhibition of cell proliferation [188].

\subsection{Pyruvate Kinase M2 (PKM2)}

PKM2 is an isoform of cytosolic enzyme pyruvate kinase (PK) involved in energy metabolism and is present in normal and cancer cells. Overexpression of PKM2 has been reported in CRC, gastric cancer and colon adenomas [190-193].

PKM2 seems a useful blood and faecal biomarker for CRC screening with its high sensitivity [191,193-199]. The disadvantage of this potential diagnostic biomarker is its poor specificity. 


\subsection{Dickkopf3 (DDK3)}

Tumor endothelial markers (TEMs) are a group of 46 genes showing stronger expression rates in the tumor endothelium of CRC tissues than in the endothelium of normal colonic mucosa [200]. The human cysteine-rich Dickkopf family includes Dkk-1, Dkk-2, Dkk-3, Dkk-4 and a unique Dkk-3-related protein called Soggy (Sgy), which belong to the class of TEMs [201].

The Dickkopf family are glycoproteins of 255-350 amino acids that contain a signal sequence of nuclear transport and share two conserved cysteine-rich domains, each of which displays a characteristic spacing of cysteines and other conserved amino acids. The N-terminal cysteine-rich domain-Dkk N (formerly termed Cys1)—is unique to the Dkks, while the C-terminal cysteine-rich domain-formerly termed Cys2-has a pattern of ten cysteines related to that described in the colipase family. These two domains are separated by a non-conserved linker region [202].

Activation of the Wnt signalling pathway participates in tumorigenesis, and the epigenetic silencing of Wnt antagonist genes, among others, is detected in CRC. Such antagonist genes are DDK genes which are epigenetically silenced in CRC cells due to promoter hypermethylation. Downregulation of Dkks expression by small interfering RNA (siRNA) contributes to the growth of cancer cells and invasiveness in vitro [203,204].

Dickkopf-3 (Dkk-3) is different from the human Dkks family, and its biological function is unclear. Dkk-3 possesses an extended N-terminal domain that precedes the Cys1 domain and an extended C-terminal region that follows Cys-2 [201]. It seems that Dkk-3 is not involved in inhibition of the Wnt signalling pathway. Zitt et al. reported that Dkk-3-positive CRCs revealed a statistically significantly higher mean microvessel count (9.70 vessels) than Dkk-3-negative cancers. Therefore, Dkk-3 is considered as a pro-angiogenic factor involved in neovascularization during CRC growth [205].

\subsection{DDK3, PKM2, IGFBP-2}

This biomarker model is able to identify early-stage CRC with $57 \%$ sensitivity for stage I and $76 \%$ sensitivity for stage II at $95 \%$ specificity. Therefore, this panel of biomarkers seems to be used as a non-invasive blood screening and/or diagnostic test and is equivalent to FOBT and FIT in terms of detection of CRC [206].

\section{Tissue Biomarkers}

\subsection{Caudal Type Homebox 2 (CDX2)}

Caudal type homeobox transcription factor 2 (CDX2) is a homeobox protein which is expressed in the nucleus of the intestinal epithelial cells. It plays a key role in the embryonic formation and differentiation of the intestine $[207,208]$. CDX2 is widely used as a sensitive and specific immunomarker for CRC. CDX2 is perceived as a tumor suppressor gene in CRC because its expression is lacking in CRC cases. Overexpression of CDX2 reduced colon cancer formation in mice. Downregulation of Ki-67 was associated with this process [209]. Overexpression of CDX2 using a hypoxia-inducible human telomerase reverse transcriptase (hTERT) promoter-driven vector suppressed malignant progression of colon cancer cells both in vivo and in vitro [209].

CDX2 expression is regulated by exchange proteins directly activated by cAMP (the Epac pathway) [208].

The Wnt/ $\beta$-catenin pathway is an important signalling pathway in embryonic development and tissue homeostasis. Aberrant $\beta$-catenin expression and overactivation of Wnt signaling participates in CRC commencement [210]. CDX2 inhibits the transcriptional activity of $\beta$-catenin in a non-transcriptional way [211]. Toth et al. showed statistically significant correlations between sustained nuclear CDX2 expression and cytoplasmic $\beta$ catenin through Mucdhl in liver metastases of CRC [212]. There are two CpG-rich sites in the promoter region of the CDX2 gene, -1570 to -1200 and -220 to +880 . The upper CpGrich site was heavily methylated in all cell lines. The lower CpG-rich site was methylated in limited CRC cell lines and was associated with down-regulation of CDX2 [207]. 
The methylation of the CDX2 gene promoter region was associated with a high risk of $\mathrm{CRC}$. The methylation rate of the promoter region of the CDX2 gene in the CRC tissue was $78.5 \%$ [213]. A lack of CDX2 expression in metastatic CRC was significantly more frequent in women with right-sided primary mucinous tumors and poorly differentiated histologic features and distant lymph node metastasis [214,215].

There were positive correlations observed between CDX2 downregulation and both high-grade and more advanced tumors with liver metastases [212,214-216]. Moreover, low CDX2 expression combined with stage T4 CRC was associated with significantly lower disease-free survival and overall survival [217]. Rajarajan et al. noted that more than half the CDX-2 positive CRCs were without metastases to regional lymph nodes [218].

Nishiuchi et al. revealed that patients with CDX2-negative CRC in stage II/III had a five-year overall survival and relapse-free survival, lower than patients with CDX2positive CRC. miR-9-5p regulates CDX2 expression. High miR-9-5p expression is positively correlated with a poor prognosis in patients with stage II/III CRC [219].

Dalebra et al. observed that patients with CDX2-negative colon cancers had a significantly shorter five-year disease-free survival (DFS) compared with patients with CDX2positive cancers. Moreover, in individuals treated with adjuvant chemotherapy, CDX2negative colon cancers in stage II were found to have a significantly increased five-year DFS (91\%) in comparison with those who did not undergo adjuvant chemotherapy (56\%) [220].

In another study, the authors showed that being CDX2-negative in the mesenchymal subgroup (CMS4) (of the consensus molecular subgroups classification of CRC) was associated with a poor prognosis for both overall and relapse-free survival [221]. The median overall survival for CDX2-negative patients was eight months and for CDX2-positive metastatic CRC patients was 39 months. The median of progression-free survival for firstline chemotherapy was significantly decreased in patients with CDX2-negative metastatic CRC (three versus ten months) [215].

Downregulation of CDX2 positively correlated with poor differentiation and mismatch repair (MMR) deficiency in CRC [212,222]. CDX2 loss was also associated with microsatellite instability [223].

Inflammatory bowel disease increases the risk for developing colitis-associated colorectal adenocarcinoma (CAC). Lack of CDX2 and YES-associated protein-1 (YAP1) expression occurred in younger patients and higher stages of CAC. Neither CDX2 nor YAP1 expression alone correlated with more aggressive histopathological features of CRC in patients with inflammatory bowel disease [224].

Interestingly, CDX2 loss is an independent poor prognostic marker in metastatic CRC patients [223]. Loss of CDX2 expression occurred more frequently in BRAF-mutated than in KRAS-mutated metastatic CRC (53\% versus 9\%). In other words, expression of CDX2 in BRAF-mutated cases was associated with a better prognosis and loss of CDX2 in KRASmutated cases was associated with a worse prognosis [223]. Patients with CDX2 loss more often had distant lymph node metastases than liver metastases. Immediate progression in first-line combination chemotherapy was seen more frequently in groups of patients with CDX2-negative than in CDX2-positive CRC tumors. Moreover, it was observed that patients with CDX2 loss had both lower overall survival and progression-free survival [223].

\subsection{Special AT-Rich Sequence-Binding Protein 2 (SATB2)}

Special AT-rich sequence-binding protein 2 (SATB2) is a part of the family of matrix attachment region-binding transcription factors regulating skeletogenesis (skeletal development and osteoblast differentiation) [225]. SATB2 upregulates osteoblast-specific genes.

SATB2 represses the expression of Hoxa2 and activates several osteoblast-specific genes by enhancing the activity of the transcription factors Runx2 and ATF4, which regulate osteoblast differentiation. This shows that SATB2 plays a role in a transcriptional network regulating skeletogenesis. SATB2 is expressed in branchial arches and in cells of the osteoblast lineage. Satb2-/- mice exhibit craniofacial abnormalities, and the same abnormalities are observed in humans carrying a translocation in SATB2 or defects in 
osteoblast differentiation and function. This synergy was genetically confirmed by bone formation defects in Satb2/Runx2 and Satb2/Atf4 double heterozygous mice [225]. Initially, SABT2 was reported as a gene on 2q32-q33 involved in isolated cleft palate defects by FitzPatrick et al. [226]. In the following years, SABT2 has been recognized as a colorectal cancer biomarker and several genetic syndromes associated with SATB2 have been described $[227,228]$. A phenotype including intellectual disability, craniofacial abnormalities (e.g., cleft palate), dental malformations and osteopenia with SATB2 defects was reported by Zarate et al. [228]. Furthermore, SATB2 was identified as a potential immunohistochemical marker of human colorectal epithelium abnormalities through screening of the Human Protein Atlas database by Magnusson et al. [227]. The researchers characterized the expression profile of SATB2 in normal human tissues using tissue microarrays. SATB2 was highly expressed in the epithelium of the appendix, colon and rectum as well as in the cerebral cortex and hippocampus, non-germinal center lymphoid cells and the ductal epithelium of the testis and epididymis [227]. SATB2 has a relatively narrow expression profile mainly in colorectal/appendiceal adenocarcinomas [229]. Its specificity is $91.2 \%$ for metastatic gastrointestinal adenocarcinoma [230].

SATB2 is relevant to a number of potential applications, including determining the origin of adenocarcinomas of unknown primary and distinguishing primary ovarian mucinous adenocarcinomas from colorectal metastases [229,231]. According to Magnusson et al., using SATB2 as a solitary marker, SATB2 was positive in $83.7 \%$ of stage III/IV colorectal adenocarcinomas, $91.4 \%$ of stage II and $92.4 \%$ of stage I of this malignancy. Based on these results and the results of the tissue microarray from other common malignant lesions, researchers suggested that the combination of SATB2 with cytokeratin 20 (CK 20) is a highly specific marker for colorectal adenocarcinoma [227].

\subsection{Glycoprotein A33 (GPA 33)}

The A33 antigen is a type I transmembrane glycoprotein of the immunoglobulin superfamily expressed in the basolateral membranes of both the proliferating cells in the lower regions of the crypts and the differentiating cells in the upper regions of crypts in the colon and in the small intestine, as well as in $95 \%$ of colon tumors [232,233]. It is a highly persistent, immobile, surface-localized protein [234]. GPA 33 is transcriptionally regulated by CDX1 in the tissues of the gastrointestinal tract [232]. The A33 glycoprotein has three structural domains: an extracellular region of 213 amino acids, a single hydrophobic transmembrane domain and a highly polar intracellular tail. The basic extracellular structure consists of domains similar to the IgG fold and the intracellular domain, including a quadruple cysteine repeat followed by a highly acidic sequence [234]. Its closest homologs comprise the Coxsackie adenovirus receptor (CAR), cortical thymocyte receptor (CTX), endothelial cell adhesion molecule (ESAM), junction adhesion molecules 1-3 (JAM) and CEA-related cell adhesion molecules (CEACAMs) [235-237]. The putative function of GPA33 is its role as an adhesion molecule. Moreover, GPA33 plays a role in trafficking proteins to vesicles. This intracellular function of GPA 33 depends on the particular phase of the cell cycle, with the peak in the G2/M phase. The lowest pGa 33 level was observed in the $S$ phase, while mRNA levels were highest in the $S$ phase but almost absent in the G1 phase [233].

PGA 33 is an immunomarker for CRC with a specificity of $85.4 \%$ and a sensitivity of $95.9 \%$.

This biomarker had similar sensitivity to CDX2 but its specificity was higher [238].

\subsection{Cadherin-17 (CDH17)}

Cadherin-17 (CDH17) is a calcium-dependent transmembrane glycoprotein and a member of the cadherin superfamily [239-241]. This cadherin is transcriptionally regulated by CDX2 via binding to elements in the $5^{\prime}$ flanking region of the gene in normal, metaplastic and neoplastic tissues of the gastrointestinal tract [242,243]. CDH17 is expressed in the basolateral plasma membrane of enterocytes and goblet cells in normal tissue $[240,244]$. 
CDH17 occurs in cholesterol-rich fractions, where it is responsible for tissue integrity [245]. Cadherin-17 has been expressed in normal, small and large intestinal, pancreatic duct epithelium and in adenocarcinomas originating from gastric, pancreatic and colorectal tissue. Less than $1 \%$ of carcinomas outside the digestive system were positive for CDH17. Therefore, another name for this glycoprotein is liver-intestine cadherin [241]. CDH17 participates in cell-cell adhesion in the intestinal epithelium through interaction with $\alpha 2 \beta 1$ integrin [240]. CDH17 modulates integrin activation and signalling to induce specific focal adhesion kinase FAK/protein tyrosine kinase2, paxillin, RhoA, Rac and Ras, the activation of which leads to the induction of extracellular signal-regulated kinase and Jun N-terminal kinase, an increase in cyclin D1 and the proliferation of colon cancer cells in liver metastasis [245]. CDH17 silencing in KM12 cells suppressed tumor growth and liver metastasis after subcutaneous or intrasplenic inoculation in nude mice. Integrins are a family of cell adhesion molecules and are receptors for extracellular matrix proteins. $\alpha 2 \beta 1$ integrin interacts with two different ligands, collagen IV and CDH17, using two different binding sites. CHD17 has a tripeptide RGD site for integrin binding as well as for some other ligands, such as fibronectin or fibrinogen [246,247]. RGD regulates $\beta 1$ integrin activation and an increase in focal adhesion kinase and ERK1/2 activation in colon cancer metastatic cells. In other words, in CDH17-positive CRC, integrin $\alpha 2 \beta 1$ binding to CDH17 is inhibited and thereby prevents integrin activation and in consequence metastasis, which may have therapeutic potential [248].

CDH17 is a useful immunohistochemical marker for the diagnosis of primary and metastatic colorectal adenocarcinomas with a specificity in the range of $50-83.8 \%$ and a sensitivity in the range of $96-100 \%[230,249,250]$. CDH17 seems slightly more sensitive than CDX2 in detecting gastrointestinal adenocarcinomas. While comparing the usefulness of CDH17 in immunohistochemical diagnostics in gastrointestinal carcinomas with CDX2, it has been observed that almost all colon adenocarcinomas (99\%) are CDH17-positive/CDX2positive [243]. In turn, the combination of CDH17 and SATB2 served as potential optimal markers for the differential diagnostics of pulmonary enteric adenocarcinoma (PEAC) and metastatic colorectal adenocarcinoma with high sensitivity $(76.92 \%)$ and specificity (100\%) [251]. PEAC is a rare type of non-small cell lung cancer with similar histological and immunohistochemical morphology to colorectal adenocarcinoma. A positive correlation between high expression of CDH17 and liver metastasis and poor survival of CRC patients has been observed [245].

\subsection{Cytokeratins}

The cytoskeletal framework consists of three kinds of cytoskeletal filaments called microfilaments, intermediate filaments and microtubules. Intermediate filaments (IFs) are responsible for organizing internal three-dimensional cellular structure and tension, giving shape to cells [252]. Moreover, IFs are the most chemically stable cellular structures, resisting high temperature, high salt and detergent solubilization [253]. All IFs have a dimeric central rod domain, which is a coiled structure consisting of two parallel $\alpha$-helices flanked by head and tail domains. IFs are classified into five categories based on their rod domain amino-acid sequences. Type 1 IFs include the acidic keratins and are present in epithelial cells. Type 2 IFs include the basic keratins and are found in epithelial cells, too. Type 3 IFs include vimentin, desmin and glial fibrillary acidic protein. Type 4 IFs occur in neurofilaments. Type 5 IFs are the nuclear lamins [254].

Cytokeratins are intermediate filament-forming protein localized in the cytoplasmic cytoskeleton. They are characteristic of epithelial cells only. Cytokeratins regulate many cellular functions, such as cell size determination, apical-basal polarization, protein translation control, organelle positioning and membrane protein targeting [253,255-259]. Nowadays, keratins have been identified and divided into two groups. Type I includes 28 (20 epithelial and 11 hair) keratins and type II includes 26 (20 epithelial and 6 hair) [260]. Similar to other IFs, keratins contain a central coiled $\alpha$-helical rod domain of about 310 amino acids, which is subdivided into subdomains (coils $1 \mathrm{~A}, 1 \mathrm{~B}, 2 \mathrm{~A}$ and $2 \mathrm{~B}$ ). The subdomains are connected 
with three linkers, L1, L12 and L2. The non-helical head domains consist of subdomains V1 and H2. The tail domains, which are non-helical, also have subdomains, H2 and V2 [254]. Cytokeratins have been widely used as immunohistochemical markers in CRC diagnostics.

\subsubsection{Cytokeratin 7 (CK7)}

Cytokeratin 7 (CK7) is a type II member of the keratin superfamily. Despite widespread expression in epithelia, its role still remains unclear. CK7 expression was significantly associated with poor tumor differentiation and the extent of tumour budding. Disease progression was more frequently observed in CK7-positive cancer patients than in CK7negative patients (52\% versus $41 \%$ ) [261].

CK7 is expressed in metastatic lymph nodes and is correlated with shorter overall survival and the presence of distant metastases at diagnosis. Interestingly, this correlation was not observed between CK7 expression in the primary tumour and overall survival. It seems that CK7 expression in metastatic lymph nodes in CRC patients is a poor prognostic factor [262].

\subsubsection{Cytokeratin 20 (CK20)}

Loss of cytokeratin 20 (CK20) has been associated with older age (above 56 years), right-sided tumours, higher grade and mucinous histology, advanced stage, increased intertumoral lymphocytic infiltration (creating Crohn's disease-like infiltrate) compared with CK20-positive tumours. Loss of CK20 is therefore correlated with lower disease-free survival and overall survival [263-265]. In turn, lack of staining or low expression of CK20 was significantly associated with poor differentiation, large tumour size and mismatch repair deficiency but was not found to significantly influence prognosis [266]. Low CK20 levels had been detected in association with high microsatellite instability [267].

\subsubsection{CK20+/CK7-}

CK20 is specific for colon, urothelial and Merkel cell carcinoma. CK7 is characteristic of glandular malignancies originating in the breast, respiratory tract, biliary tract and Mullerian epithelium [253,268,269]. The CK20+/CK7- profile is expressed in about 75-95\% of CRC cases [253,268-271]. Therefore, the CK20+/CK7- profile is characteristic of colon carcinoma and is a widely used diagnostic tool to determine the site of origin in metastatic carcinomas [266,272]. According to Al-Maghrabi et al., the most common profile was CK20+/CK7-, observed in $60.4 \%$ of CRC cases, and CK20-/CK7-, observed in $35.4 \%$ of cases. A mixed CK20+/CK7+ and CK20-/CK7+ profile was reported in $2.1 \%$. Al-Maghrabi et al. did not note statistically significant correlations between CK20/CK7 immunohistochemical profiles and clinicopathological characteristics (such as age, sex, tumour size and location, lymph node status, etc.), prognosis and survival [272]. Other investigators revealed a positive correlation between a CK20+/CK7+ profile and an advanced stage of CRC [266,273]. In another study, the CK20-/CK7+ profile was characteristic of right-sided and high-grade colon cancer [274].

\subsubsection{Cytokeratin 15 (CK15)}

Cytokeratin 15 (CK15) is a type I keratin lacking a defined type II partner and participates in maintaining cytoplasmic stability [275-277]. CK15 is present in the basal keratinocytes of stratified epithelia, while abnormal expression of CK15 is involved in tumorigenesis and cancer progression [278-283].

CK15 was found to be highly expressed in colorectal cancer tissue [284] and was correlated with a poorer prognosis. CRC patients with high CK15 expression had significantly lower overall survival compared with those patients with low CK15 expression. High CK15 expression positively correlated with the differentiation and staging of CRC. CK15 might be treated as an independent prognostic factor in CRC [284]. 


\subsubsection{Cytokeratin 18 (CK18)}

Cytokeratin 18 (CK18) is upregulated in many types of human cancers (e.g., hepatocellular carcinoma, cervical carcinoma) and is correlated with clinical progression and worse prognoses $[285,286]$. CK18 participates in a diverse range of normal cellular processes, such as cell proliferation, the cell cycle, apoptosis, motility and cell signalling [287].

CK18 expression is increased in CRC cancer tissue in comparison with adjacent normal colorectal tissue. Moreover, high CK18 expression is positively correlated with advanced clinical stage, metastases to lymph nodes or other solid organs and poor differentiation. CK18 overexpression is an independent predictor of overall survival in CRC patients with upregulated CK18 expression in tumour tissue. Downregulation of CK18 expression inhibited CRC cell viability, migration and invasion in an in vitro study [288].

\subsection{Telomerase}

Telomeres are regions protecting the ends of chromosomes and contain unique hexameric repeats (TTAGGG)n. They regulate chromosomal integrity and cell life span. When a critical shortened length is reached, cells begin to undergo replicative senescence $[289,290]$. Telomerase is a ribonucleoprotein enzyme complex whose activity helps cells to avoid senescence. Telomerase contains a telomere-specific reverse transcriptase (hTERT) which shows structural and functional similarities to viral transcriptases. The second component is an internal RNA (telomerase RNA-hTR) template sequence on which the telomeric repeats are synthesized $[289,291]$.

Telomerase is present in immortalized cells, such as germ line cells, and $80-90 \%$ of human cancer cells [292].

The overexpression of hTERT increases replicative potential in CRCs and the risk of recurrence [289]. CRC patients with elevated expression of hTERT were found to have a significantly worse median overall survival compared with patients who had tumours characterized by low expression of hTERT (37 months vs. not reached), regardless of stage or systemic treatment given. The hazard ratio for death was 15 times higher in patients with metastatic disease and with elevated hTERT than in patients with low hTERT expression [289].

In other studies, it was observed that elevated hTERT expression was associated with a more advanced stage and a worse prognosis, patients with colorectal cancer having lower disease-free survival (DFS) and overall survival (OS) [293,294].

hTERT seems to be a biomarker for recurrence which can be used to monitor responses to systemic therapy.

Telomere length is an independent prognostic factor in CRC. Cancers with mean telomere lengths less than $6.35 \mathrm{~Kb}$ have a better prognosis [295]. Noncoding telomeric repeat-containing RNAs (TERRAs) regulate the enzyme telomerase, influencing telomere length. Bae et al. revealed that 18p TERRA expression was significantly correlated with telomere length. In a multivariate analysis, it has been shown that 18p TERRA expression was a significant independent prognostic factor for disease-free survival in CRC patients [296]. Ayomamlitis et al. reported that a significantly higher level of telomerase activity was found in colon cancer tissue (especially in right-sided tumors vs. left-sided) than in rectal cancer tissue. The same increase of telomerase activity was observed in normal adjacent tissue in patients with colon cancer in comparison with those with rectal cancer. Colon cancers had higer hTERT activity than rectal cancers [297]. In another study it was observed that high telomerase activity was significantly correlated with a worse prognosis compared to cancers showing moderate or low telomerase activity [298]. Telomere length and hTERT expression in cancerous colon tissue were significantly correlated with histopathological features and overall survival. Cancer tissue had significantly shorter telomeres than surrounding normal mucosa. Longer telomeres were noted in advanced CRC (stage II-IV) compared to stage I tumors. Significantly lower hTERT expression levels were found in CRC tissue compared to adjacent normal mucosa [299,300]. 
However, telomerase activity does not always correlate with hTERT expression in colon cancer possibly because of the presence of hTERT in infiltrating lymphocytes in normal mucosa [301]. Therefore, the measurement of hTERT alone may overestimate the actual presence of telomerase within both normal and cancerous bowel epithelial cells [302].

Table 6 presents the results of published studies in which telomerase activity in colon cancer cases was evaluated.

Table 6. According to Chen and Chen in modification: telomerase activity in colon cancer [292].

\begin{tabular}{ccc}
\hline Author/Year & Material & Colon Cancer [\%] \\
\hline Engelhardt/1997 [303] & colon tissue & 90 \\
Yoshida/1997 [304] & colon tissue & 92 \\
Myung/2005 [305] & colon tissue & 97 \\
Tatsumato/2000 [298] & colon tissue & 96 \\
Kawanishi-Kabata/2002 [306] & colon tissue & 80 \\
Myung/2005*[305] & colon tissue & 94 \\
Fang/1999 [307] & colon biopsy & 88.5 \\
Yoshida/1997 [304] & colon washing & 60 \\
Ishibashi/1999 [308] & colon washing & 58 \\
Myung/2005 [305] & colon washing & 62 \\
\hline detection of hTERT. & &
\end{tabular}

The specificity of telomerase activity and hTERT was found to be excellent, but the sensitivity was relatively low [292] (see Table 6).

Thanks to recent medical advances, telomere length measurement and analysis of telomerase expression have shown promise as useful molecular biomarkers for early CRC cancer detection and monitoring and for identifying patients with a poor prognosis [309].

\section{Diagnostic Stool Biomarkers for Colorectal Cancer}

\subsection{Guaiac-Based Faecal Occult Blood Testing (gFOBT)}

Guaiac-based faecal occult blood testing (gFOBT) has been the most used screening technique for colorectal cancer worldwide for many years. It is a cheap and non-invasive method [2]. This test is used to identify people with $>10 \mathrm{~mL}$ rectal blood loss daily. Low sensitivity (50\% for colorectal cancer and 20\% for adenomas), especially in the early stages of colorectal cancer, and low acceptance have been the main disadvantages of this method [310]. The next significant limitation of gFOBT is its low specificity. False positive results occurred after taking nonsteroidal anti-inflammatory drugs and compounds with peroxidase properties (such as meat and fruit), while taking vitamin $C$ in high doses gave false negative results. It is necessary to follow a special diet and to take stool samples three time in order to perform gFOBT, which is a big inconvenience for patients [311].

Burch et al. reported a meta-analysis of 59 studies concerning FOBT efficiency. Sensitivities for the detection of all neoplasms ranged from $6.2 \%$ to $83.3 \%$ [312].

There are different types of FOB test, such as chemical and immunochromatographic, which vary in terms of execution technique, sensitivity and specificity.

Fluorescent long DNA (FL-DNA) is a non-invasive method which uses a qPCR assay in order to evaluate long fragments of stool DNA by quantitative amplification of specific targets of genomic DNA. In the case of DNA fragments longer than $200 \mathrm{bp}$, it correlates with high specificity of colorectal lesion detection. This test can be used with an immunochemical-based faecal occult blood test (iFOBT) of the same sample [313]. Randomized trials showed that the effectiveness of gFOBT as well as iFOBT holds for the detection of left-sided lesions only [314].

Interesting screening options are the combination of FOBT with other methods which increase the detection rate.

Combining iFOBT and a faecal microRNA-106a (miRNA) test (FmiRT) was found to improve the sensitivity (70.9\%) and specificity $(96.3 \%)$ of CRC detection. One quarter of CRC patients with false-negative iFOBT results had positive FmiRNA tests [18]. On 
the other hand, another study suggested that the combination of FOBT and M2-PK tests increased sensitivity to $90 \%$ and specificity to $62 \%$ [315]. The tumour pyruvate kinase tumour (Tumour M2 PK) is a dimeric form of the glycosylation enzyme and belongs to type M2 pyruvate kinase. The enzyme is the catalyst of the last reaction stage of the glycolytic sequence and converts phosphoenolpyruvate into pyruvate, being responsible for the production of ATP within the metabolic pathway in which it participates.

Ten-thousand asymptomatic participants aged 50-75 years were enrolled in the Prevention Project for Neoplasia of the Colon and Rectum (PRENEC) conducted in Chile. Participants with positive iFOBT results or a family history of CRC underwent a colonoscopy. The results of this screening procedure were compared with a previous national screening program (PREVICOLON). The adenoma detection rate was 26.7\% in PREVICOLON and $41.8 \%$ in PRENEC. The cancer detection rate was $1.1 \%$ and $6 \%$, respectively. A high return rate for samples and necessary contact with participants to invite them for colonoscopy are pivotal factors in CRC screening with iFOBT [316].

Nowadays, FOBT has been replaced by other screening tests, such as faecal immunochemical testing (FIT), multitarget stool (mt-sDNA), the FOBT DNA test and miRNA tests [317-321].

\subsection{Faecal Immunochemical Test (FIT)}

The faecal immunochemical test (FIT) is a modification of the guaiac-based FOBT, measuring the presence of blood degraded by digestive proteolytic enzymes [322]. The true positive rates of FIT were low for early stage CRC (in the range of 18-33\%) and advanced adenomas (in the range of 9-19\%) [323,324].

FIT has a wide range of sensitivities for all stages of CRC, starting at $25 \%$ and reaching as high as 79\% [325,326]. Sensitivities of FIT were higher in cases of more advanced CRC: for T3, sensitivity was $83 \%$ (ranging from $68 \%$ to $91 \%$ ), and for $\mathrm{T} 1$ was $40 \%$ (ranging from $21 \%$ to $64 \%$ ) [327].

Interestingly, a meta-analysis of studies from Europe and Australia revealed that FIT CRC screening uptake was significantly lower (16\%) in men aged 40-75 years than women. Additionally, women were found (non-significantly) to participate more often in FIT screening than men in North America and South America. A similar uptake of FIT-based screening was noted in Asian studies [328].

In a case-control study conducted on asymptomatic counting, over 23,000 participants of a Chilean population who had positive FIT results or a family history of CRC underwent a colonoscopy. According to this study, male sex, a positive family history, dietary habits (low intake of fibres and/or cereals) and older age (seventh and eighth decade of life) were the main risk factors of CRC [329].

\subsection{Stool DNA (sDNA)}

Stool specimens seems to be more suitable for early detection of CRC than blood samples due to the fact that exfoliating tumor cells appear in the large intestine or rectal lumen much earlier than the beginning of vascular invasion by tumor cells during colorectal carcinogenesis [132]. Tumor cells excreted with stools have DNA containing aberrant genetic and epigenetic alterations which are potential biomarkers for cancer diagnosis.

The stool DNA test is the first noninvasive screening tool that targets both human hemoglobin and a panel of specific genetic alterations [330]. The Food and Drugs Administration approved multi-target stool DNA (mt-sDNA) for colorectal cancer screening in average-risk patients in 2014 [320,331-333]. There is a multi-target stool DNA test (Cologuard, a combination of NDRG4 and BMP3 DNA methylation, KRAS mutations, and haemoglobin) and a plasma SEPT9 DNA methylation test (Epi proColon), which has been used more widely in clinical practice so far [120].

Many international oncological guidelines recommend mt-sDNA tests as an option for colorectal cancer screening. Stool-based DNA testing provides an entirely noninvasive population-based screening strategy which patients can perform easier than FOBT. 
The sensitivity of mt-sDNA testing for detection of CRC is as high as $90 \%$ in asymptomatic individuals [321,331,334,335]. The specificity with DNA testing ranges from $86.6 \%$ to $98 \%[334,336]$. One-third of patients diagnosed in this way with CRC have advanced neoplasia [333]. Positive results in mt-sDNA tests correlate significantly with multiple lesions, larger precancerous lesions and lesions with tubulovillous architectures [337]. Moreover, in most cases, positive mt-sDNA is linked with a right-side location of CRC in colonoscopies [338]. According to Wang et al., there is no association between an sDNA test for SDC2 methylation and clinopathological features of CRCs, such as age, TNM stage, tumor location (colon vs. rectum) and tumor differentiation, except for gender [336].

Multi-target stool DNA tests have high positive predictive value. In case of a positive mtsDNA test, a colonoscopy is the next step in the diagnosis of a colorectal neoplasm [338-340].

The sensitivity of detection of advanced adenomas and sessile serrated polyps measuring $1 \mathrm{~cm}$ or more in the greatest dimension with mt-sDNA is $42.4 \%$ [331,334,336].

A meta-analysis of 13 studies including over 700 patients using faecal gene methylation as a CRC screening method revealed that sensitivity for CRC detection was 78\%, specificity was $90 \%$ and diagnostic objective response was $48 \%$. The sensitivity for the detection of adenomas was $63 \%$ and the specificity was $93 \%$ [341].

Pickhardt et al. presented an interesting study in which an (FDA) approved mt-sDNA test was compared with CT colonography in asymptomatic individuals. Overall detection rates for advanced neoplastic lesions were significantly greater with CT colonography screening $(5.0 \%)$ than with the mt-sDNA test $(2.7 \%)$. Overall detection rates for CRC were $0.31 \%$ and $0.23 \%$, respectively [342].

The main limitation of this method is false positive results (i.e., a positive mt-sDNA test and a negative high-quality colonoscopy performed after DNA testing) [334,338].

There are several meta-analyses assessing the diagnostic value of stool DNA testing [343-348]. Zhai et al. reported the pooled sensitivities for single- and multiple-gene stool DNA (methylation and mutation) tests in CRC to be $48.0 \%$ and $77.8 \%$, respectively, and the pooled specificity for single- and multiple-gene assays to be $97.0 \%$ and $92.7 \%$, respectively [344]. In another study (for methylated single- and multiple-gene tests in stool samples), Luo et al. demonstrated an overall sensitivity of $62 \%$ and $54 \%$, respectively, and a specificity of $89 \%$ and $88 \%$ in CRC and adenoma patients, respectively [346]. Zhang et al. reported a sensitivity ranging from $51 \%$ for adenomas to $73 \%$ for CRCs and a specificity of $92 \%$ [345]. In another meta-analysis, the pooled sensitivity of the combined single- and multiple-gene DNA hypermethylation tests on stool specimens was 0.71 and specificity was 0.92 for [343]. In Mojtabanezhads et al.'s meta-analysis, this method was shown to have a lower efficiency than reported in previous meta-analyses: the sensitivity for CRC and adenomas was $56.5 \%$ and $32.6 \%$, respectively, and the specificity was $93.2 \%$ for CRC and adenomas [347]. In a published meta-analysis including results obtained for over 16,000 patients, it was revealed that the sensitivity of the stool methylation test with a single SDC2 gene was $83.1 \%$ and specificity was $91.2 \%$, what is promising in case of this diagnostic method as employed instead of colonoscopy [348].

The most important studies of non-invasive, methylated DNA stool biomarkers used in colorectal cancer detection are collected in Table 7.

Table 7. According to Loktionov in modification: non-invasive, methylated DNA stool biomarkers used in colorectal cancer detection [1].

\begin{tabular}{ccccc}
\hline $\begin{array}{c}\text { Author/Year of } \\
\text { Publication }\end{array}$ & Marker Type/Method & Stool Biomarker & Sensitivity [\%] & Specificity [\%] \\
\hline Muller/2004 [349] & DNA methylation & SFRP2 methylation & $\begin{array}{c}\text { training set: 90 } \\
\text { independent test set: 77 }\end{array}$ & $\begin{array}{c}\text { training set:77 } \\
\text { indepedent test set: 77 }\end{array}$ \\
\hline Petko/2005 [350] & DNA methylation & $\begin{array}{c}\text { CDKN2A and MGMT } \\
\text { methylation }\end{array}$ & $\begin{array}{c}\text { CDKN2A:50 } \\
\text { MGMT: 71 }\end{array}$ \\
\hline
\end{tabular}


Table 7. Cont.

\begin{tabular}{|c|c|c|c|c|}
\hline $\begin{array}{c}\text { Author/Year of } \\
\text { Publication }\end{array}$ & Marker Type/Method & Stool Biomarker & Sensitivity [\%] & Specificity [\%] \\
\hline Huang/2007 [351] & DNA methylation & SFRP2 methylation & $\begin{array}{c}\text { CRC: } 94.252 .4 \\
\text { advanced adenomas: } 52.4\end{array}$ & 93 \\
\hline Itzkowitz/2007 [352] & $\begin{array}{l}\text { DNA integrity assay } \\
\text { (DIA) }\end{array}$ & Vimentin methylation & $\begin{array}{c}\text { vimentin methylation: } \\
72.5 \\
\text { vimentin methylation + } \\
\text { DIA: } 87.5\end{array}$ & $\begin{array}{c}\text { vimentin methylation: } \\
86.9 \text { vimentin } \\
\text { methylation + DIA: } 82\end{array}$ \\
\hline Wang/2008 [353] & DNA methylation & SFRP2 methylation & $\begin{array}{c}\text { CRC: } 87, \\
\text { advanced adenomas: } 61 \text {, } \\
\text { hyperplastic polyps: } 42.3 \\
\text { overall: } 76.8\end{array}$ & \\
\hline Itzkowitz/2008 [354] & DNA methylation & Vimentin methylation & 86 & 82 \\
\hline $\begin{array}{c}\text { Oberwalder } / 2008 \\
{[355]}\end{array}$ & DNA methylation & SFRP2 methylation & adenomas: 46 & adenomas: 100 \\
\hline Glockner/2009 [356] & DNA methylation & $\begin{array}{l}\text { tissue factor pathway } \\
\text { inhibitor } 2 \text { (TFPI2) } \\
\text { methylation }\end{array}$ & I-III stage of CRC: 76-89 & $\begin{array}{c}\text { I-III stage of CRC: } \\
79-93\end{array}$ \\
\hline Melotte/2009 [357] & DNA methylation & NDRG4 methylation & 61 & 93 \\
\hline $\begin{array}{l}\text { Hellebrekers } / 2009 \\
{[358]}\end{array}$ & DNA methylation & GATA4/5 methylation & $\begin{array}{l}\text { training set: } 71 \\
\text { validation set: } 51\end{array}$ & $\begin{array}{c}\text { training set: } 84 \\
\text { validation set: } 93\end{array}$ \\
\hline $\begin{array}{c}\text { Ausch } / 2009 \\
\text { [359] }\end{array}$ & DNA methylation & $\begin{array}{l}\text { ITGA4 integrin, alpha } 4 \\
\text { (antigen CD49D, alpha } \\
4 \text { subunit of VLA-4 } \\
\text { receptor) methylation }\end{array}$ & adenomas: 69 & adenomas: 79 \\
\hline Nagasaka/2009 [360] & DNA methylation & $\begin{array}{l}\text { SFRP2 methylation } \\
\text { RASSF2 methylation }\end{array}$ & $\begin{array}{c}\text { CRC: } 86 \text { adenomas: } 41 \\
\text { CRC: } 45.3 \text { adenomas: } \\
12.6\end{array}$ & 94.7 \\
\hline $\begin{array}{c}\text { Chang/2010 } \\
\text { [361] }\end{array}$ & DNA methylation & $\begin{array}{c}\text { ITGA4, SFRP2 } \\
\text { methylation }\end{array}$ & $\begin{array}{c}\text { CRC: } 70 \\
\text { adenomas:72 }\end{array}$ & panel: 96.8 \\
\hline Zhang/2011 [362] & DNA methylation & $\begin{array}{l}\text { Vimentin, oncostatin M } \\
\text { receptor (OMSR) and } \\
\text { tissue factor pathway } \\
\text { inhibitor } 2 \text { (TFPI2) } \\
\text { methylation }\end{array}$ & $\begin{array}{c}\text { CRC: } 86.7 \\
\text { adenomas:76.5 }\end{array}$ & 86.7 \\
\hline Bosch/2012 [363] & DNA methylation & $\begin{array}{l}\text { Phosphatase and Actin } \\
\text { Regulator } 3 \\
\text { (PHACTR3) } \\
\text { methylation }\end{array}$ & $\begin{array}{l}\text { training set: } 55 \\
\text { CRC: } 66 \text { and adenomas } \\
\text { (validation set): } 32\end{array}$ & $\begin{array}{c}\text { training set: } 95 \\
\text { validation set: } 100\end{array}$ \\
\hline $\begin{array}{l}\text { Ahlquist/2012 } \\
\text { [132] }\end{array}$ & DNA methylation & $\begin{array}{c}\text { BMP3, NDRG4, } \\
\text { vimentin, TFPI2 } \\
\text { methylation; mutant } \\
\text { KRAS }\end{array}$ & $\begin{array}{l}\text { adenomas: } 82 \\
\text { CRC: } 87\end{array}$ & \\
\hline Kisiel/2013 [364] & DNA methylation & $\begin{array}{l}\text { BMP3 and NDRG4 } \\
\text { methylation }\end{array}$ & $\begin{array}{l}\text { CRC: } 100 \\
\text { high grade dysplasia: } 100 \\
\text { low grade dysplasia: } 67\end{array}$ & 89 \\
\hline Amiot/2014 [365] & DNA methylation & $\begin{array}{l}\text { Wif1, ALX4, vimentin } \\
\text { methylation }\end{array}$ & $\begin{array}{c}\text { Wif1:19 } \\
\text { ALX4:11 } \\
\text { vimentin:33 }\end{array}$ & $\begin{array}{l}\text { Wif1 and ALX4: } 99 \\
\text { vimentin: } 100\end{array}$ \\
\hline
\end{tabular}


Table 7. Cont.

\begin{tabular}{|c|c|c|c|c|}
\hline $\begin{array}{l}\text { Author/Year of } \\
\text { Publication }\end{array}$ & Marker Type/Method & Stool Biomarker & Sensitivity [\%] & Specificity [\%] \\
\hline Imperiale/2014 [334] & $\begin{array}{l}\text { DNA mutation, DNA } \\
\text { methylation, DNA } \\
\text { amount and protein } \\
\text { testing }\end{array}$ & $\begin{array}{c}\text { K-ras mutation, } \\
B M P 3 \text { and NDRG4 } \\
\text { promoter methylation, DNA } \\
\text { measurement by } \beta \text { - } \\
\text { actin assessment and test for } \\
\text { haemoglobin } \\
(\text { FIT) }\end{array}$ & 92.3 & 86.6 \\
\hline Zhang/2014 [366] & DNA methylation & SFRP2 methylation & $\begin{array}{c}\text { CRC: } 56.3 \\
\text { adenomas: } 51.4\end{array}$ & 100 \\
\hline $\mathrm{Wu} / 2014$ [367] & DNA methylation & $\begin{array}{l}\text { miR-34a } \\
\text { methylation } \\
\text { miR-34b/c } \\
\text { methylation }\end{array}$ & $\begin{array}{c}76.8 \\
95\end{array}$ & $\begin{array}{l}93.6 \\
100\end{array}$ \\
\hline Xiao/2014 [368] & $\begin{array}{l}\text { methylation-sensitive } \\
\text { high-resolution melting } \\
\text { (MS-HRM) }\end{array}$ & $\begin{array}{l}\text { SNCA and FNB1 genes } \\
\text { Vimentin (VIM) and } \\
\text { SFRP2 genes }\end{array}$ & $\begin{array}{l}84.3 \\
92.5\end{array}$ & $\begin{array}{c}93.30 \\
91.2\end{array}$ \\
\hline Teixeira/2015 [369] & human DNA & total human DNA & 66 & 89.8 \\
\hline $\mathrm{Li} / 2015$ [370] & DNA methylation & $\begin{array}{c}\text { hypermethylated SNCA and } \\
\text { FBN1 }\end{array}$ & 84.3 & 93.3 \\
\hline Park/2017 [371] & DNA methylation & $\begin{array}{l}\text { methylated SFRP2, TFPI2, } \\
\text { NDRG4, BMP3 promoters }\end{array}$ & $\begin{array}{c}\text { CRC: } 94.3 \\
\text { adenomas: } 72.2\end{array}$ & 55 \\
\hline $\begin{array}{c}\text { Mojtabanezhad /2018 } \\
\text { [347] }\end{array}$ & DNA methylation & SFRP1 and SFRP2 methylation & $\begin{array}{c}\text { CRC: } 56.5 \\
\text { adenomas:32.6 }\end{array}$ & 93.2 \\
\hline Sun/2019 [372] & DNA methylation & $\begin{array}{l}\text { methylation of SDC2 and } \\
\text { SFRP2, KRAS mutations and } \\
\text { hemoglobin }\end{array}$ & 91.4 & 86.1 \\
\hline Liu/2019 [373] & DNA methylation & $\begin{array}{c}\text { methylation levels of SFRP2, } \\
\text { SFRP1, TFPI2, BMP3, NDRG4, } \\
\text { SPG20, and BMP3 plus } \\
\text { NDRG4 genes }\end{array}$ & 70 & 80 \\
\hline Bosch/2019 [337] & DNA methylation & $\begin{array}{c}\text { K-ras mutation, } \\
B M P 3 \text { and NDRG4 } \\
\text { promoter methylation, and } \\
\text { hemogloblin }\end{array}$ & $\begin{array}{l}\text { precancerous } \\
\text { lesions: } 46\end{array}$ & 89 \\
\hline Chen/2019 [374] & DNA methylation & SEPT9, NDRG4, SDC2 & $\begin{array}{c}\text { CRC: } 90 \\
\text { adenomas: } 78\end{array}$ & \\
\hline $\mathrm{Liu} / 2020$ [375] & DNA methylation & $\begin{array}{l}\text { COL4A1, COL4A2, TLX2, and } \\
\text { ITGA4 }\end{array}$ & $82.5-92.5$ & $88.0-96.4$ \\
\hline Jin/2020 [376] & DNA methylation & NDRG4, SDC2 & 81.82 & 93.75 \\
\hline Zhao/2020 [377] & DNA methylation & SEPT9, SDC2 & 92.3 & 93.2 \\
\hline
\end{tabular}

\subsection{Faecal Immunochemical Test (FIT) and Stool DNA Test}

Other diagnostic tools, such as DNA- or RNA-based tests, evaluated in a communitybased population, were found to improve the efficiency of the FIT method [378].

The sensitivity of multi-target stool DNA (mt-sDNA) testing for the detection of CRC in asymptomatic individuals at average risk of cancer was significantly higher compared to FIT: $92 \%$ vs. $74 \%$, respectively $[331,334]$. Similarly, the sensitivity for detecting advanced precancerous lesions was significantly higher for mt-sDNA testing $(42.4 \%)$ than for FIT (23.8\%) [334]. The specificity of the mt-sDNA test was $86.6 \%$ and the FIT had a specificity of $94.9 \%$ [335]. Carether et al.'s study has comfirmed that using mt-sDNA testing increased 
the detection of advanced adenomas and sessile serrated polyps (42\% and $42 \%$ ) compared to $(24 \%$ and $5 \%)$ FIT. On the other hand, overall specificity for detection of all lesions was lower when using mt-sDNA (87\%) than FIT (95\%) [331]. Mu et al. have demonstrated that a DNA-FIT test increased the sensitivity of detection to $97.5 \%$ for CRC and to $53.1 \%$ for advanced adenomas [379]. The positive detection rate of mt-sDNA as well as FIT has been found to be independent of age, gender, tumor location and tumor size [380].

\subsection{Methylation of DNA}

Colorectal cancer is a heterogenous disease involving epigenetic alterations of the DNA, especially CpG island methylation, which occurs at a higher frequency than genetic mutations. Hypermethylation induces transcriptional silencing or downregulation of suppressor genes, what is one of the links to carcinogenesis. Epigenetic alterations are heritable changes in the structure or chemical composition of DNA or histone and other DNA-bound proteins affecting gene expression, but they do not result in changes to the DNA sequence [381]. The methylation of DNA involves the addition of a methyl group to the $5^{\prime}$ position of the pyrimidine ring of cytosines to produce 5-methylcytosine catalysed by DNA methyltransferases in CpG dinucleotide sequences localized in short CpG-rich DNA regions (CpG islands), centromeric repeats and rDNA [350,356,381]. Hypermethylation inactivates tumour suppressor genes at each step of carcinogenesis from polyps to colorectal adenocarcinomas. Many genes, such as APC, MLH1, MGMT, SFRP1, SFRP2, CDK2A, TIMP3, VIM, SEPT, CDH1 and HLTF, are methylated in CRC, especially within the promoter region [382].

Quantitative DNA methylation analysis revealed that approximately 20\% of colorectal cancers have a high frequency of promoter methylation (the CpG island methylator phenothype, CIMP). These CIMP cancers are associated with female sex, old age, proximal colon location, poor differentiation and harbouring of $M S I, K R A S$ and BRAF mutations. There are two subclasses of CIMP tumours: CIMP-high tumours (or CIMP1) have BRAF mutations and are microsatellite-unstable; CIMP-low (or CIMP2) tumours have KRAS mutations [381]

Thousands of abnormally methylated CpG positions in CRC genomes are often located in non-coding parts of genes. A good example of such an alteration might be the Syndecan-2 gene.

Syndecan-2 (SDC2) (called fibroglycan) belongs to the Syndecan family and encodes a transmembrane type I heparen sulfate proteoglycan. The SDC2 promotor region is frequently hipermethylated in colorectal cancer and has been detected in blood and stool samples from colorectal cancer patients [382-384]. The expression of SDC2 is upregulated by demethylation and inhibition of histone deacetylation in colorectal cancer cells with SDC2 methylation. In other words, the expression of SDC2 is suppressed by promoter methylation [384]. DNA methylation tests are not correlated with tumor differentiation, TNM stage, location, sex or age [336,385]. Faecal-originated DNA containing methylated SDC2 might be a promising biomarker with high sensitivity (77.4-90.2\%) and specificity $(88.2-98 \%)$ for the noninvasive detection of colorectal cancer $[336,384,386]$. The very rare false positive results can be an effect of occasional elevated methylation status in healthy individuals [336]. On the other hand, methylated SDC2 in faecal samples was detected in $42-66.7 \%$ of advanced adenomas and $24.4 \%$ of non-advanced adenomas; therefore. this method might not be suitable for detecting precancerous lesions [336,384,385].

Colorectal cancer patients with hypermethylation of the secreted frizzled related protein 2 (SFRP2) gene in tumor tissue, stool and blood samples had a significantly lower overall survival than those with negative results for SFRP2 methylation analyses. Serum SFRP2 methylation was significantly correlated with poor differentiation grade, higher TNM stage with positive lymph node metastasis status and deeper tumor invasion in the bowel wall [387].

N-Myc downstream-regulated gene 4 (NDRG4) plays a role in cell growth and differentiation. NDRG4 is downregulated in colorectal cancer [357]. 
Septins are a group of scaffolding proteins existing in stable six to eight-subunit core heteromers. The octamer constitutes of two molecules of each of SEPT2, SEPT6, SEPT7 and SEPT9 subunits [388].

The SEPT9 gene encodes a GTP-binding protein involved in cell proliferation and migration, cytokinesis and angiogenesis [389]. Hypermethylation of the promoter region of the Septin 9 gene disturbs its transcription and is an important factor in carcinogenesis [115]. Aberrant methylation of this gene occurs in CRC tissues [132].

Bone morphogenetic protein 3 (BMP3) belongs to a transforming growth factor-beta (TGF $\beta$ ) superfamily of cytokines. BMP3 binds to cell surface receptors and influences the regulation of the transcription of SMAD4 genes and, in consequence, inhibits growth. Downregulation of the BMP3 tumor suppressor gene might be involved in the early stages of CRC tumorigenesis [390].

\subsection{Stool miRNA}

miRNAs are small (18-25 nucleotide in length) noncoding RNAs (ncRNA) participating in post-transcriptional regulation of gene expression [332,391]. miRNAs are integrated into the RNA-induced silencing complex. This complex regulates the expression of target messenger RNAs (mRNAs) through post-transcriptional processing by binding primarily to the $3^{\prime}$ untranslated region ( $3^{\prime}$ UTR) of target mRNAs, which leads to the inhibition of translation or mRNA degradation [392,393]. ncRNAs are abnormally expressed in CRC and can behave as tumor suppressors (tsmiRs) or as oncogenes (oncomiRs), depending on the downstream target genes or pathways they regulate. It is interesting that the clinopathological features and prognostic factors of CRC correlate with the expression status of miRNAs [394,395].

The possibility of a distinction between the miRNA profile of CRC and normal bowel mucosa miRNAs has contributed to the development of a new screening tool, diagnostic and prognostic biomarkers. Obtaining samples from CRC tissue, plasma and stool is easy and reproducible [391]. There are some limitations to stool miRNA analysis. Firstly, faecal features, such as density, volume, etc., are changed daily, which makes the standardization of protocols difficult. Secondly, it is necessary to distinguish three sources of faecal miRNA: cell-free miRNAs from faecal homogenates, exosomal miRNAs from faecal exosomes and faecal colonocyte miRNAs [396].

The first report concerning the association between miRNA (miRNA-143 and miR-145) and CRC and precancerous lesions was published almost twenty years ago [394]. Currently, the list of tested miRNAs and their possible clinical applications is still being extended.

Noninvasive stool miRNA biomarkers for CRC detection are summarized in Table 8.

Table 8. According to Loktionov in modification noninvasive stool miRNA biomarker for CRC detection [1].

\begin{tabular}{cccc}
\hline Author/Year & Marker and Detection Method & Sensitivity [\%] & Specificity [\%] \\
\hline Koga/2010 [397] & miR-17-92 cluster, upregulated & & \\
& $\begin{array}{c}\text { miRNA panel: miR-17-92 cluster (miR-17, miR-18a, } \\
\text { miR-19a, miR-19b, miR-20a, and miR-92a), miR-21, } \\
\text { and miR-135, upregulated }\end{array}$ & 74 & 81 \\
\hline Kalimutho/2011 [398] & miR-144* & & 79 \\
Wu/2012 [75] & miR-92a, upregulated & 71 (CRC) 56 (A) & 73 \\
\hline
\end{tabular}

miR-7, miR-17, miR-20a, miR-21, miR-92a, miR-96, miR-106a, miR-134, miR-183, miR-196a,

Ahmed/2013 [399] miR-199a-3p, miR214, miR-9, miR-29b, miR-127-5p, miR-138, miR-143, miR-146a, miR-222 and miR-938-

$\mathrm{N} / \mathrm{A}^{*} \quad \mathrm{~N} / \mathrm{A}$ *
findings: upregulated 
Table 8. Cont.

\begin{tabular}{|c|c|c|c|}
\hline Author/Year & Marker and Detection Method & Sensitivity [\%] & Specificity [\%] \\
\hline Koga/2013 [18] & miRNA -106a upregulated and iFOBT & 34.2 & 97.2 \\
\hline $\mathrm{Wu} / 2014[74]$ & miR-135b, upregulated & $\begin{array}{c}78(\mathrm{CRC}) \\
73(\mathrm{AA}) \\
62(\mathrm{~A})\end{array}$ & 68 \\
\hline Yau/2014 [400] & $\begin{array}{l}\text { miR-221, upregulated } \\
\text { miR-18a, upregulated }\end{array}$ & $\begin{array}{l}62 \\
61\end{array}$ & $\begin{array}{l}74 \\
69\end{array}$ \\
\hline Phua/2014 [401] & $\begin{array}{c}\text { miR-223 } \\
\text { miR-451 } \\
\text { both upregulated }\end{array}$ & $\begin{array}{l}77 \\
88\end{array}$ & $\begin{array}{c}96 \\
100\end{array}$ \\
\hline Slaby/2016 [91] & $\begin{array}{c}\text { miR-18a, upregulated } \\
\text { miR-20a, upregulated } \\
\text { miR-21, upregulated } \\
\text { miR-92a, upregulated } \\
\text { miR-106a, upregulated } \\
\text { miR-135b, upregulated } \\
\text { miR-144 *, upregulated } \\
\text { miR-221, upregulated } \\
\text { miR-223 and miR-92a, both upregulated } \\
\text { panel miR-17-93 cluster and miR-135b, all } \\
\text { upregulated }\end{array}$ & $\begin{array}{l}61 \\
55 \\
56 \\
72 \\
34 \\
78 \\
74 \\
62 \\
97 \\
74\end{array}$ & $\begin{array}{l}69 \\
82 \\
73 \\
73 \\
97 \\
68 \\
87 \\
74 \\
75 \\
79\end{array}$ \\
\hline Chang/2016 [102] & $\begin{array}{l}\text { miR-223, upregulated } \\
\text { miR-92a, upregulated }\end{array}$ & $\begin{array}{l}73 \\
71\end{array}$ & $\begin{array}{l}82 \\
79\end{array}$ \\
\hline Zhu/2016 [402] & $\begin{array}{l}\text { miR-29a, miR-223, miR-224, } \\
\text { finding: reduced expression in CRC stools }\end{array}$ & $\mathrm{N} / \mathrm{A}$ & $\mathrm{N} / \mathrm{A}$ \\
\hline Yau/2016 [403] & miR-20a, upregulated & 55 & 82 \\
\hline $\mathrm{Wu} / 2017$ [404] & $\begin{array}{l}\text { miRNA panel: miR-144-5p, miR- 451a miR-20b- 5p, } \\
\text { all upregulated }\end{array}$ & 66 & 95 \\
\hline Bastaminejad/2017 [405] & miR-21, upregulated & 86 & 81 \\
\hline Choi/2019 [406] & $\begin{array}{c}\text { miR-21, upregulated } \\
\text { miR-92a, upregulated } \\
\text { miR-144*, upregulated } \\
\text { miR-17-3p, upregulated }\end{array}$ & $\begin{array}{l}79 \\
89 \\
78 \\
67\end{array}$ & $\begin{array}{l}48 \\
51 \\
66 \\
70\end{array}$ \\
\hline $\mathrm{Li} / 2020$ [407] & miR-135b-5p, upregulated & 96 & 74 \\
\hline Duran-Sanchon/2020 [408] & $\begin{array}{l}\text { miR-421 and miR-27a-3p, both upregulated, } \\
\text { finding: AUC -0.93 (for CRC) }\end{array}$ & $\mathrm{N} / \mathrm{A}$ & $\mathrm{N} / \mathrm{A}$ \\
\hline
\end{tabular}

* N/A-not applicable.

\subsection{Faecal Bacteria}

It is a well-known fact that large intestine microflora called microbiota have been implicated in the tumorigenesis of colorectal cancer [409,410]. The quantity of bacteria in the large intestine is $10^{12}$ cells per $\mathrm{ml}$ and cancer risk in this location is 12-fold greater than in the small intenstine, where the quantity of bacteria is $10^{2}$ cells per ml. These observations suggest that colon cancer might be a bacteria-related disease [409].

Depending on diet, drug intake and lifestyle, intestinal microbiota in healthy individuals vary in different countries [409]. Furthermore, the presence of blood in stools could influence the composition of the microbiome in the gut. Species such as Bacteroides uniformis, Collinsella aerofaciens, Eggerthella lenta and Clostridium symbiosum demonstrate increased abundance in patients with blood in their stools [411]. Tjalsma et al. proposed the hypothesis of carcinogenesis according to which some bacteria called 'passengers' (Fusobacterium spp., Streptococcus gallolyticus subsp. gallolyticus, Clostridium septicum and Coriobacteriaceae (Slackia and Collinsella spp.), the genus Roseburia and the genus Faecalibacterium) stimulate 
other bacteria called 'drivers' (such as Bacteroides, Shigella, Citrobacter and Salmonella or E. coli) which play a role in the first steps of colorectal cancer development [410]. Driver bacteria adhere to the epithelium of bowel mucosa and damage epithelial DNA, contributing to the initiation of CRC. It is interesting that the bacteria found in stools are not always the same bacteria as those attached to the epithelium. Moreover, bacterial drivers may disappear from neoplastic tissue as they are replaced by passenger bacteria [410]. Some individuals are carriers of a higher proportion of driver bacteria than others, which can be the result of genetic conditioning and lifestyle, and for which reason they might have a higher risk of CRC [409].

Therefore, alterations in microbiota are potentially good diagnostic biomarkers for CRC [412]. Special attention has been paid by researchers to Fusobacterium nucleatum, an anaerobic, gram-negative oral commensal, which is a pathogenetic factor of, e.g., inflammatory bowel disease and CRC [413-415].

An increase of Fusobacterium nucleatum in stools was associated with the presence of Fusobacterium nucleatum in the tumor tissue of colorectal cancer patients and had a positive correlation with tumor stage [416,417]. Moreover, the presence of Fusobacterium nucleatum was positively correlated with cholesteryl esters and sphingomyelin metabolite classes in stools [417]. There were no differences in stool microbiota between colorectal cancer and adenomas because Fusobacterium nucleatum infiltrate different cells in the same way and activate their growth using FadA adhesin, which binds to E-cadherin, influencing oncogenic responses $[417,418]$.

In another study, Suehiro et al., using droplet digital polymerase chain reaction (PCR), showed a higher number of copies of the Fusobacterium nucleatum genome in CRC advanced adenomas and carcinomas in situ in CRC patients' stools compared to healthy individuals. This could indicate that Fusobacterium nucleatum is involved in the early stages of colorectal tumorigenesis [419]. In the next study, Fusobacterium nucleatum were detected in CRC patients' stools in higher levels than in patients with dysplasia and controls with a sensitivity of $69.2 \%$ for CRC [420]. Similarly, DNA of colibactin-producing bacteria (clbA) was found to be present significantly more often in samples isolated from the stools of patients with CRC compared to patients with dysplasia or healthy volunteers. The sensitivity of an individual marker for $\mathrm{clbA} 1+$ bacteria was $56.4 \%$. The specificity of both assays was close to $80 \%$ [420].

The ratio of Fusobacterium nucleatum to Bifidobacterium probiotic $(\mathrm{Fn} / \mathrm{Bb})$ proved to have a high sensitivity $(84.6 \%)$ and specificity $(92.3 \%)$ in detecting CRC. The combination ratio of $\mathrm{Fn} / \mathrm{Bb}$ and Fusobacterium nucleatum to Faecalibacterium prausnitzii (Fn/Fp) increased sensitivity to $90 \%$ in detecting CRC in stage I [421].

The detection of alterations in intestinal abundance of four faecal bacteria, Fusobacterium nucleatum, Bacteroides clarus, Roseburia intestinalis and Clostridium hathewayi, in combination with FIT improved the sensitivity for CRC detection to $92.8 \%$ and the specificity to $81.5 \%$ [422]. Bacterial markers with FIT were correlated with stage I, II and III CRC but not stage IV [422].

In Wong's et al. study, a 132-fold higher abundance of Fusobacterium nucleatum in CRC patients and a 3.8-fold increase was observed in patients with advanced adenomas. The combination of FIT and Fusobacterium nucleatum markers resulted in improved detection rates for CRC with a sensitivity of $92.3 \%$ and a specificity of $93.0 \%$, without significant difference between cancer stages. In turn, the sensitivity was $38.6 \%$ and the specificity was $89.0 \%$ for advanced adenomas [423].

Clos-Garcia et al. observed a high level of Parvimonas anaerobic bacteria in CRC stools' microbiota, which was associated with the increased activation of methane-related pathways [417]. In turn, Adlercreutzia bacteria, producing equol from isoflavonoids consumed in the diet, were more numerous in adenoma patients' feces and could be used as an early CRC biomarker [417].

Using Clostridum symbiosum in the diagnosis of CRC is a very interesting option. It is still unclear if Clostridium symbiosum is a cause or a result of CRC. Xie et al. showed that 
the abundance of Clostridium symbiosum in stools was positively correlated with both early and advanced stages of CRC and advanced adenomas. The sensitivity of this method was approximately two-fold higher compared to FIT tests both for CRC and adenomas. The combination of Clostridium symbiosum detection and FIT increased sensitivity by 4-24\%, and nearly one-third more patients were diagnosed with early-stage CRC [424].

\subsection{The Gut Microbiota and miRNA}

The molecular interactions between host and gut microbiota are mediated by proteins, metabolites and small RNA (sRNA), human micro RNA (hsa miRNA) and human small noncoding RNA (hsa sncRNA) [425]. It is a well-known fact that Fusobacterium nucleatum and Epstein-Barr viral sRNA are upregulated in CRC tissue but not in adjacent normal mucosa [426]. Futhermore, Fusobacterium nucleatum and Escherichia coli can pick up and incorporate faecal miRNAs, which modulate bacterial gene transcripts and influence bacterial growth [427]. An encouraging result of Tarallo's et al. study was the extraction of a human and microbial sRNA signature which can be used to improve diagnosis of CRC by combined analyses of metagenomic and small RNA sequencing (sRNA-Seq) data.

hsa-miR-21-5p, hsa-miR-200b-3p, hsa-miR-1290-5p, hsa-miR-4792-3p and hsa-miR1246-3p were found to be significantly upregulated in CRC cases; therefore, the five hsamiRNAs could represent a new class of biomarkers for this disease. The differential expression analysis showed that hsa-miR-30-5p might be a good candidate biomarker for adenomas [425].

\section{Volatile Organic Compounds (VOC)}

Cancer metabolomes are defined as cancer-specific metabolites of low molecular weight below $1500 \mathrm{Da}$. Some of these metabolites are VOCs—organic chemicals that have a high vapour pressure at room temperature. Their production and release might be altered in some diseases, such as cancer, and could therefore be used in their detection. Genetic and proteinic changes contributing to the peroxidation of the cell membrane might thereby create CRC-specific VOCs [428]. In addition, the alterations in gut microbiota influence directly the profile of VOC production [429-431].

\subsection{Urinary VOCs}

Urinary biomarkers could be an option for non-invasive colorectal cancer screening instead of stool testing due to the fact that urine is simple to collect and easy to store. Additionally, this procedure is reproducible and has high patient acceptability.

Several studies utilised a mass spectrometry technology named field asymmetric ion mobility spectrometry (FAIMS) and gas chromatography coupled with ion mobility spectrometry (GC-IMS) as techniques for detecting VOCs in urine [432,433].

The sensitivity ranged from $69 \%$ to $88 \%$ with $60 \%$ specificity for urinary VOCs, using FAIMS technology [432,434]. In a very interesting study, Widlak et al. observed that the additional detection of urinary VOCs in the FIT false-negative (i.e., failed to detect cancer) increased the detection of CRC. Using both faecal (FIT and faecal calprotectin) and urinary VOC detection increased diagnostic accuracy for CRC from $80 \%$ to $97 \%$ and specificity to $72 \%$ in patients with lower gastrointestinal symptoms [435].

Mozdiak et al. tested the urinary VOCs from FOBT-positive patients using FAIMS and GC-IMS. The ability to distinguish CRC from healthy controls using FAIMS and GGC-IMS was high, with an AUC of 0.98 and 0.82 , sensitivity of $100 \%$ and $80 \%$ and specificity of $92 \%$ and $83 \%$, respectively. Urinary VOCs demonstrate a high sensitivity for adenoma detection. Disadvantages, such as the lack of specificity and high false positive rate, do not allow this method to be used as a standard for adenoma detection [433].

\subsection{Stool VOCs}

Based on current data analysis, faecal VOCs seems to have high diagnostic value for CRC and adenoma screening. All the papers have reported increased levels of amino acids 
and short chain fatty acids and decreased levels of bile acids and polyol alcohols in the gas phase of faeces [436].

Faecal VOCs from individuals who had a positive FOBT were analysed by selected ion flow tube mass spectrometry (SIFT-MS). Ions most likely originated from hydrogen sulphide, dimethyl sulphide and dimethyl disulphide reach statistically significantly higher levels in samples from high-risk compared to low-risk subjects. Results using multivariate methods show that the test gives a correct classification of $75 \%$, with $78 \%$ specificity and $72 \%$ sensitivity on FOBT-positive samples, offering a potentially effective alternative to FOB [431].

Hydrogen sulphide is one of the stool VOCs responsible for the development of CRC.

Hydrogen sulphide is produced by endogenous enzymatic reactions in the bowel and microbiota in the gut. Lower levels of hydrogen sulphide are normal but higher levels (above $2.4 \mathrm{mmol} / \mathrm{kg}$ ) are toxic. Its non-competitive binding to cytochrome c oxydase inhibits the binding of oxygen to cytochrome c oxydase, leading to the reduction of cellular adenosine triphosphate (ATP).

Hydrogen sulphide plays a role in the function of the ATP-sensitive potassium channels, the activation of which in turn influences the balance of the biological effects of hydrogen sulphide [431]. Higher levels of hydrogen sulphide in the lumen and faeces disturb the balance of microbiota. This phenomenon occurs in, e.g., CRC patients. Additionally, hydrogen sulphide leads to DNA damage which causes CRC [431].

Bond et al. identified a three-faecal VOC panel consisting of propan-2-ol derived from acetone, hexan-2-one and ethyl 3-methyl- butanoate, arising as the product of reaction between ethanol and 3-methylbutaninoic, the presence of which is positively correlated with CRC diagnosis [437].

In another study, faecal gas compounds from CRC patients were analysed using gas chromatography. The amount of hydrogen was significantly lower in patients with T3-T4 tumors and advanced stage disease than in other CRC patients, showing $90 \%$ sensitivity, $57.7 \%$ specificity and $75 \%$ accuracy of detection. The amount of methyl mercaptan, sulphur-containing gas, was significantly higher in CRC patients. Increased amounts of methyl merceptan could be produced by Fusobacterium nucleatum from L-methionine by L-methionine-a-deamino-c-mercaptomethane-lyase [438]. A second hypothesis assumes that methyl mercaptan is an effect of a reaction between sulphur-containing amino acids with glucose or lactic acid. In turn, lactic acid is produced by cancer cells (the Warburg effect) [439].

\subsection{Breath VOCs}

Exhaled breath changes its chemical composition depending on the health or state of disease. Sampling of breath is non-invasive and simple; however, only a few breath tests are sufficient. Cancer-specific VOCs do not appear normally in exhaled breath and can be used for detecting CRC.

Altmore at al. showed that the initial specificity of gas chromatography-mass spectrometry (GC-MS) through the identification and quantification of VOCs in exhaled breath was $83 \%$, with a sensitivity of $86 \%$ and an overall accuracy of $85 \%$ [439].

In the next study, the breath samples were assessed with GC-MS, which identified four VOCs: acetone, ethyl acetate, ethanol and 4-methyloctane. Levels of acetone and ethyl acetate were higher in CRC; in turn, levels of ethanol and 4-methyloctane were lower in the CRC group. The sensor technology (based on a breath pattern to identify different groups) allowed CRC patients to be distinguished from healthy individuals with $85 \%$ sensitivity, $94 \%$ specificity and $91 \%$ accuracy. Sensitivity was $100 \%$ in distinguishing advanced adenomas and healthy individuals using the sensor technique; specificity and accuracy were $88 \%$ and $94 \%$, respectively [440].

Wang et al. used phase microextraction/gas chromatography-mass spectrometry (SPME/GC-MS) to analyse exhaled VOCs. In CRC patients, VOC samples contained significantly higher levels of cyclohexanone, 2,2-dimethyldecane, dodecane, 4-ethyl-1- 
octyn-3-ol, ethylaniline, cyclooctylmethanol, trans-2-dodecen-1-ol and 3-hydroxy-2,4,4trimethylpentyl 2-methylpropanoate, but significantly lower levels of 6-t-butyl-2,2,9,9tetramethyl-3,5-decadien-7-yne [441].

According to current data analysis for VOCs in the gas phase of excreted materials, breath VOCs seem to present an innovative and promising approach to CRC screening. However, a lack of a unified technique, a long list of substrates used for diagnosis and the low availability of this method are the main disadvantages of this potential diagnostic tool [434].

\section{European Society of Medical Oncology (ESMO) Recommendations for Screening}

The ESMO recommends that adults aged 50 or older until the approximate age of 74 years with an average risk of CRC should carry out a complete colonoscopy with an optimal repetition interval for a negative test every 10 years. Flexible sigmoidoscopy undergone every 5-10 years may be an alternative for those who refuse colonoscopy. In order to reduce the risk of a right colon neoplasm, it is recommended that a combination of an endoscopy with a faecal occult blood test be carried out annually [442].

Other invasive (i.e., capsule colonoscopy) tests are not recommended for screening.

A non-invasive test (FIT) is recommended in average-risk adults from the age of 50 not already taking part in colonoscopic screening programmes, with the optimal frequency being every year and no later than every three years. When the test result is positive, a colonoscopy is recommended [442].

Other non-invasive tests, such as mtDNA-based tests or tests using other markers (e.g., M2-PK), should also be performed [442].

\section{Colrectal Cancer Screening and the COVID-19 Pandemic}

The COVID-19 pandemic has contributed to the delay and/or cancelation of many important diagnostic procedures, such as colonoscopies for colorectal cancer screening.

Therefore, alternative diagnostic methods meeting requirements that can be introduced instead of demanding complex medical procedures and intensive involvement of medical personnel should be sought.

Faecal DNA tests have a potential to be useful screening tools in place of colonoscopies [443,444]. In Gachabayovs et al.'s published meta-analysis, encouraged by their results, the authors suggest that stool methylation tests with the single SDC2 gene is a promising diagnostic method instead of colonoscopy in the COVID-19 pandemic [351].

Analysis of results from over 16,000 patients revealed that the sensitivity of the stool methylation test with the single SDC2 gene was $83.1 \%$ and that the specificity was $91.2 \%$, showing it to be a promising diagnostic method instead of colonoscopy [348].

The next screening solution that could be conducted safely during the COVID-19 pandemic is colon capsule endoscopy (CCE), an innovative technique for evaluating mucosa of the colon and an interesting screening option [445]. Among individuals with one or more adenomas $6 \mathrm{~mm}$ or larger, specificity was $82 \%$ and sensitivity in those cases was $88 \%$ [446]. On the other hand, the high cost of the procedure, a lack of experienced physicians, the risk of capsule retention, obstruction and possible bowel perforation are significant limitations to CCE [447].

\section{CRC Screening Today and Future Challenges}

Better understanding of the molecular genetics and epigenetics of colon polyps and $\mathrm{CRC}$ has led to the development of molecular marker assays for CRC screening. Approaches to $C R C$ detection reviewed in this paper are undoubtedly impressive in terms of numbers but often disappointing in outcomes due to the fact that "ideal" screening or diagnostic biomarkers should be highly sensitive and specific, easy to perform, cheap and commonly available. Therefore, the combination of the FIT and colonoscopy has still remained the strategy of choice in CRC screening across the world. Screening methods based on blood testing were supplemented by a new biomarker, methylated gene septin 9 (mSEPT9), in the 
last few years after approval by the FDA. It is worth recalling doubts related to use of this test in detecting precancerous lesions, however [125]. Currently, screening guidelines are being updated.

A challenge for the future is the standardization of protocols, such as extraction and quantification methods, as well as normalization techniques. Secondly, it is necessary to translate biomarkers to the clinical context. Thirdly, the elimination of sophisticated laboratory equipment would be optimal, with simple implementations that are not expensive and not time-consuming.

Let us hope that existing progress in CRC biomarker research will result in the development of new non-invasive tests in CRC screening and thereby the prevention of this disease.

Author Contributions: Conceptualization: A.L.Z. and P.P.; writing-original draft preparation: A.L.Z. and P.P.; writing - review and editing: A.L.Z. and P.P.; funding acquisition: P.P. The authors contributed equally to the work. All authors have read and agreed to the published version of the manuscript.

Funding: This work was funded by Jagiellonian University Medical College.

Institutional Review Board Statement: Not applicable.

Informed Consent Statement: Not applicable.

Data Availability Statement: Not applicable.

Conflicts of Interest: The authors declare no conflict of interest.

\section{References}

1. Loktionov, A. Biomarkers for detecting colorectal cancer non-invasively: DNA, RNA or proteins? World J. Gastrointest. Oncol. 2020, 12, 124-148. [CrossRef] [PubMed]

2. Binefa, G.; Rodriguez-Moranta, F.; Teule, A.; Medina-Hayas, M. Colorectal cancer: From prevention to personalized medicine. World J. Gastroenterol. 2014, 20, 6786-6808. [CrossRef]

3. Kit, A.H.; Nielsen, H.M.; Tost, J. DNA methylation based biomarkers: Practical considerations and applications. Biochimie 2012, 94, 2314-2337. [CrossRef] [PubMed]

4. Gan, X.; Wang, T.; Chen, Z.Y.; Zhang, K.H. Blood-derived molecular signatures as biomarker panels for the early detection of colorectal cancer. Mol. Biol. Rep. 2020, 47, 8159-8168. [CrossRef] [PubMed]

5. Mansour, H. Cell-free nucleic acids as noninvasive biomarkers for colorectal cancer detection. Front. Genet. 2014, 5, 182. [CrossRef]

6. Marcuello, M.; Vymetalkova, V.; Neves, R.P.L.; Duran-Sanchon, S.; Vedeld, H.M.; Tham, E.; van Dalum, G.; Flugen, G.; Garcia-Barberan, V.; Fijneman, R.J.; et al. Circulating biomarkers for early detection and clinical management of colorectal cancer. Mol. Asp. Med. 2019, 69, 107-122. [CrossRef]

7. Danese, E.; Montagnana, M.; Lippi, G. Circulating molecular biomarkers for screening or early diagnosis of colorectal cancer: Which is ready for prime time? Ann. Transl. Med. 2019, 7, 610. [CrossRef]

8. Willis, B.; Gorse, E.; Lee, V. Role of liquid biopsies in colorectal cancer. Curr. Probl. Cancer 2018, 42, 593-600. [CrossRef]

9. Normanno, N.; Cervantes, A.; Ciardiello, F.; De Luca, A.; Pinto, C. The liquid biopsy in the management of colorectal cancer patients: Current applications and future scenarios. Cancer Treat. Rev. 2018, 70, 1-8. [CrossRef]

10. Vacante, M.; Ciuni, R.; Basile, F.; Biondi, A. The liquid biopsy in the management of colorectal cancer: An overview. Biomedicines 2020, 8, 308. [CrossRef]

11. Ding, Y.; Li, W.; Wang, K.; Xu, C.; Hao, M.; Ding, L. Perspectives of the application of liquid biopsy in colorectal cancer. Biomed. Res. Int. 2020, 2020, 6843180. [CrossRef]

12. Alix-Panabieres, C.; Pantel, K. Real-time liquid biopsy: Circulating tumor cells versus circulating tumor DNA. Ann. Transl. Med. 2013, 1, 18.

13. Tsai, W.S.; Watson, D.; Chang, Y.; Hsieh, B.; Shao, H.J.; Wu, J.C.; Lai, J.M.; Chang, S.E.; Javey, M.; Mei, R.; et al. Prospective clinical study of circulating tumor cells for colorectal cancer screening. J. Clin. Oncol. 2018, 36, 556. [CrossRef]

14. Flamini, E.; Mercatali, L.; Nanni, O.; Calistri, D.; Nunziatini, R.; Zoli, W.; Rosetti, P.; Gardini, N.; Lattuneddu, A.; Verdecchia, G.M.; et al. Free DNA and carcinoembryonic antigen serum levels: An important combination for diagnosis of colorectal cancer. Clin. Cancer Res. 2006, 12, 6985-6988. [CrossRef] [PubMed]

15. Sun, J.; Fei, F.; Zhang, M.; Li, Y.; Zhan, X.; Zhu, S.; Zhang, S. The role of mSEPT9 in screening, diagnosis, and recurrence monitoring of colorectal cancer. BMC Cancer 2019, 19, 450. [CrossRef] [PubMed]

16. Link, A.; Balaguer, F.; Shen, Y.; Nagasaka, T.; Lozano, J.J.; Boland, R.C.; Goel, A. Fecal microRNAs as novel biomarkers for colon cancer screening. Cancer Epidemiol. Biomark. Prev. 2010, 19, 1766-1774. [CrossRef] 
17. Wang, Y.N.; Chen, Z.H.; Chen, W.C. Novel circulating microRNAs expression profile in colon cancer: A pilot study. Eur. J. Med. Res. 2017, 22, 51. [CrossRef]

18. Koga, Y.; Yamazaki, N.; Yamamoto, Y.; Yamamoto, S.; Saito, N.; Kakugawa, Y.; Otake, Y.; Matsumoto, M.; Matsumura, Y. Fecal miR-106a is a useful marker for colorectal cancer patients with false-negative results in immunochemical fecal occult blood test. Cancer Epidemiol. Biomark. Prev. 2013, 22, 1844-1852. [CrossRef] [PubMed]

19. Sazanov, A.A.; Kiselyova, E.V.; Zakharenko, A.A.; Romanov, M.N.; Zaraysky, M.I. Plasma and saliva miR-21 expression in colorectal cancer patients. J. Appl. Genet. 2017, 58, 231-237. [CrossRef] [PubMed]

20. Yan, S.; Jiang, Y.; Liang, C.; Cheng, M.; Jin, C.; Duan, Q.; Xu, D.; Yang, L.; Zhang, X.; Ren, B.; et al. Exosomal miR-6803-5p as potential diagnostic and prognostic marker in colorectal cancer. J. Cell Biochem. 2018, 119, 4113-4119. [CrossRef]

21. Peng, Z.Y.; Gu, R.H.; Yan, B. Downregulation of exosome-encapsulated miR-548c-5p is associated with poor prognosis in colorectal cancer. J. Cell Biochem. 2018, 120, 1457-1463. [CrossRef]

22. Liu, T.; Zhang, X.; Gao, S.; Jing, F.; Yang, Y.; Du, L.; Zheng, G.; Li, P.; Li, C.; Wang, C. Exosomal long noncoding RNA CRNDE-h as a novel serum-based biomarker for diagnosis and prognosis of colorectal cancer. Oncotarget 2016, 7, 85551-85563. [CrossRef] [PubMed]

23. Liu, X.; Pan, B.; Sun, L.; Chen, X.; Zeng, K.; Hu, X.; Xu, T.; Xu, M.; Wang, S. Circulating exosomal miR-27a and miR-130a act as novel diagnostic and prognostic biomarkers of colorectal cancer. Cancer Epidemiol. Biomark. Prev. 2018, 27, 746-754. [CrossRef] [PubMed]

24. Racila, E.; Euhus, D.; Weiss, A.J.; Rao, C.; McConnell Tertappen, L.W.; Uhr, J.W. Detection and characterization of carcinoma cells in the blood. Proc. Natl. Acad. Sci. USA 1998, 95, 4589-4594. [CrossRef] [PubMed]

25. Marcuello, M.; Duran-Sanchon, S.; Moreno, L.; Lozano, J.J.; Bujanda, L.; Castells, A.; Gironella, M. Analysis of a 6-miRNA signature in serum from colorectal cancer screening participants as non-invasive biomarkers for advanced adenoma and colorectal cancer detection. Cancers 2019, 11, 1542. [CrossRef]

26. Alix-Panabières, C.; Pantel, K. Challenges in circulating tumour cell research. Nat. Rev. Cancer 2014, 14, 623-631. [CrossRef] [PubMed]

27. Su, W.; Yu, H.; Jiang, L.; Chen, W.; Li, H.; Qin, J. Integrated microfluidic device for enrichment and identification of circulating tumor cells from the blood of patients with colorectal cancer. Dis. Markers 2019, 2019, 8945974. [CrossRef] [PubMed]

28. Mandel, P.M.; Métais, P. Les acides nucléiques du plasma sanguin chez l’Homme [French]. C. R. Seances Soc. Biol. Fil. 1948, 142, 241-243.

29. Thierry, A.R.; El Messaoudi, S.; Gahan, P.B.; Anker, P.; Stroun, M. Origins, structures, and functions of circulating DNA in oncology. Cancer Metastasis Rev. 2016, 35, 347-376. [CrossRef]

30. Kahlert, C.; Melo, S.A.; Protopopov, A.; Tang, J.; Seth, S.; Koch, M.; Zhang, J.; Weitz, J.; Chin, L.; Futreal, A.; et al. Identification of doublestranded genomic DNA spanning all chromosomes with mutated KRAS and p53 DNA in the serum exosomes of patients with pancreatic cancer. J. Biol. Chem. 2014, 289, 3869-3875. [CrossRef]

31. Thakur, B.K.; Zhang, H.; Becker, A.; Matei, I.; Huang, Y.; Costa-Silva, B.; Zheng, Y.; Hoshino, A.; Brazier, H.; Xiang, J.; et al. Double-stranded DNA in exosomes: A novel biomarker in cancer detection. Cell Res. 2014, 24, 766-769. [CrossRef]

32. Stroun, M.; Lyautey, J.; Lederrey, C.; Olson-Sand, A.; Anker, P. About the possible origin and mechanism of circulating DNA apoptosis and active DNA release. Clin. Chim. Acta 2001, 313, 139-142. [CrossRef]

33. Turk, B. Targeting proteases: Successes, failures and future prospects. Nat. Rev. Drug Discov. 2006, 5, 785-799. [CrossRef]

34. Roth, C.; Pantel, K.; Müller, V.; Rack, B.; Kasimir-Bauer, S.; Janni, W.; Schwarzenbach, H. Apoptosis-related deregulation of proteolytic activities and high serum levels of circulating nucleosomes and DNA in blood correlate with breast cancer progression. BMC Cancer 2011, 11, 4. [CrossRef]

35. López-Otín, C.; Matrisian, L.M. Emerging roles of proteases in tumour suppression. Nat. Rev. Cancer 2007, 7, 800-808. [CrossRef] [PubMed]

36. Crowley, E.; Nicolantonio, F.D.; Loupakis, F.; Bardelli, A. Liquid biopsy: Monitoring cancer-genetics in the blood. Nat. Rev. Clin. Oncol. 2013, 10, 472-484. [CrossRef]

37. Schwarzenbach, H.; Hoon, D.S.; Pantel, K. Cell-free nucleic acids as biomarkers in cancer patients. Nat. Rev. Cancer 2011, 11, 426-437. [CrossRef] [PubMed]

38. To, E.W.H.; Chan, K.C.A.; Leung, S.F.; Chan, L.Y.S.; To, K.F.; Chan, A.T.C.; Johnson, P.J.; Lo, Y.M.D. Rapid clearance of plasma Epstein-Barr virus DNA after surgical treatment of nasopharyngeal carcinoma. Clin. Cancer Res. 2003, 9, 3254-3259.

39. Jung, M.; Klotzek, S.; Lewandowski, M.; Fleischhacker, M.; Jung, K. Changes in concentration of DNA in serum and plasma during storage of blood samples. Clin. Chem. 2003, 49, 1028-1029. [CrossRef]

40. El Messaoudi, S.; Rolet, F.; Mouliere, F.; Thierry, A.R. Circulating cell free DNA: Preanalytical considerations. Clin. Chim. Acta 2013, 424, 222-230. [CrossRef] [PubMed]

41. Rodrigues, F.E.; Simon, D.; Ikuta, N.; Klovan, C.; Dannebrock, F.A.; Oliveira de Oliveira, C.; Regner, A. Elevated cell-free plasma DNA level as an independent predictor of mortality in patients with severe traumatic brain injury. J. Neurotrauma 2014, 31, 1639-1646. [CrossRef]

42. Tsai, N.W.; Lin, T.K.; Chen, S.D.; Chang, W.N.; Wang, H.C.; Yang, T.M.; Lin, Y.J.; Jan, C.R.; Huang, C.R.; Liou, C.W.; et al. The value of serial plasma nuclear and mitochondrial DNA levels in patients with acute ischemic stroke. Clin. Chim. Acta 2011, 412, 476-479. [CrossRef] [PubMed] 
43. Breitbach, S.; Sterzing, B.; Magallanes, C.; Tug, S.; Simon, P. Direct measurement of cell-free DNA from serially collected capillary plasma during incremental exercise. J. Appl. Physiol. 2014, 117, 119-130. [CrossRef]

44. De Vlaminck, I.; Valantine, H.A.; Snyder, T.M.; Strehl, C.; Cohen, G.; Luikart, H.; Neff, N.F.; Okamoto, J.; Bernstein, D.; Weisshaar, D.; et al. Circulating cell-free DNA enables noninvasive diagnosis of heart transplant rejection. Sci. Transl. Med. 2014, 6, 241ra77. [CrossRef] [PubMed]

45. De Vlaminck, I.; Martin, L.; Kertesz, M.; Patel, K.; Kowarsky, M.; Strehl, C.; Garrett, C.; Luikart, H.; Neff, N.F.; Okamoto, J.; et al. Noninvasive monitoring of infection and rejection after lung transplantation. Proc. Natl. Acad. Sci. USA 2015, 112, 13336-13341. [CrossRef]

46. Osumi, H.; Shinozaki, E.; Yamaguchi, K.; Zembutsu, H. Clinical utility of circulating tumor DNA for colorectal cancer. Cancer Sci. 2019, 110, 1148-1155. [CrossRef]

47. Chen, X.; Wang, L.; Lou, J. Nanotechnology strategies for the analysis of circulating tumor DNA: A review. Med. Sci. Monit. 2020, 26, e921040. [CrossRef]

48. Bettegowda, C.; Sausen, M.; Leary, R.J.; Kinde, I.; Wang, Y.; Agrawal, N.; Bartlett, B.R.; Wang, H.; Luber, B.; Alani, R.M.; et al. Detection of circulating tumor DNA in early- and late-stage human malignancies. Sci. Transl. Med. 2014, 6, 224ra24. [CrossRef] [PubMed]

49. Lee, R.C.; Feinbaum, R.L.; Ambros, V. The C. elegans heterochronic gene lin-4 encodes small RNAs with antisense complementarity to lin-14. Cell 1993, 75, 843-854. [CrossRef]

50. Vychytilova-Faltejskova, P.; Svobodova-Kovarikova, A.; Grolich, T.; Prochazka, V.; Slaba, K.; Machackova, T.; Halamkova, J.; Svoboda, M.; Kala, Z.; Kiss, I.; et al. MicroRNA biogenesis pathway genes are deregulated in colorectal cancer. Int. J. Mol. Sci. 2019, 20, 4460. [CrossRef]

51. Van Roosbroeck, K.; Calin, G.A. Cancer hallmarks and MicroRNAs: The therapeutic connection. Adv. Cancer Res. 2017, 135, 119-149. [PubMed]

52. Kim, V.N. MicroRNA biogenesis: Coordinated cropping and dicing. Nat. Rev. Mol. Cell. Biol. 2005, 6, 376-385. [CrossRef] [PubMed]

53. Borchert, G.M.; Lanier, W.; Davidson, B.L. RNA polymerase III transcribes human microRNAs. Nat. Struct. Mol. Biol. 2006, 13, 1097-1101. [CrossRef] [PubMed]

54. Lee, Y.; Kim, M.; Han, J.; Yeom, K.H.; Lee, S.; Baek, S.H.; Kim, V.N. MicroRNA genes are transcribed by RNA polymerase II. Embo J. 2004, 23, 4051-4060. [CrossRef]

55. Gregory, R.I.; Yan, K.P.; Amuthan, G.; Chendrimada, T.; Doratotaj, B.; Cooch, N.; Shiekhattar, R. The Microprocessor complex mediates the genesis of microRNAs. Nature 2004, 432, 235-240. [CrossRef]

56. Fareh, M.; Yeom, K.H.; Haagsma, A.C.; Chauhan, S.; Heo, I.; Joo, C. TRBP ensures efficient Dicer processing of precursor microRNA in RNA-crowded environments. Nat. Commun. 2016, 7, 13694. [CrossRef]

57. Yang, J.S.; Maurin, T.; Robine, N.; Rasmussen, K.D.; Jeffrey, K.L.; Chandwani, R.; Papapetrou, E.P.; Sadelain, M.; O'Carroll, D.; Lai, E.C. Conserved vertebrate mir-451 provides a platform for Dicer-independent, Ago2-mediated microRNA biogenesis. Proc. Natl. Acad. Sci. USA 2010, 107, 15163-15168. [CrossRef]

58. Ruby, J.G.; Jan, C.H.; Bartel, D.P. Intronic microRNA precursors that bypass Drosha processing. Nature 2007, 448, 83-86. [CrossRef]

59. Okamura, K.; Lai, E.C. Endogenous small interfering RNAs in animals. Nat. Rev. Mol. Cell Biol. 2008, 9, 673-678. [CrossRef]

60. Scott, M.S.; Ono, M. From snoRNA to miRNA: Dual function regulatory non-coding RNAs. Biochimie 2011, 93, 1987-1992. [CrossRef]

61. Bartel, D.P. MicroRNAs: Genomics, biogenesis, mechanism, and function. Cell 2004, 116, 281-297. [CrossRef]

62. Cuellar, T.L.; McManus, M.T. MicroRNAs and endocrine biology. J. Endocrinol. 2005, 187, 327-332. [CrossRef]

63. Chen, X.; Liang, H.; Zhang, J.; Zen, K.; Zhang, C.Y. Secreted microRNAs: A new form of intercellular communication. Trends Cell Biol. 2012, 22, 125-132. [CrossRef]

64. Friedman, R.C.; Farh, K.K.H.; Burge, C.B.; Bartel, D.P. Most mammalian mRNAsare conserved targets of microRNAs. Genome Res. 2009, 19, 92-105. [CrossRef]

65. McDonald, J.S.; Milosevic, D.; Reddi, H.V.; Grebe, S.K.; Algeciras-Schimnich, A. Analysis of circulating microRNA: Preanalytical and analytical challenges. Clin. Chem. 2011, 57, 833-840. [CrossRef] [PubMed]

66. Li, H.; Zhang, H.; Lu, G.; Li, Q.; Gu, J.; Song, Y.; Gao, S.; Ding, Y. Mechanism analysis of colorectal cancer according to the microRNA expression profile. Oncol. Lett. 2016, 12, 2329-2336. [CrossRef] [PubMed]

67. Bartley, A.N.; Yao, H.; Barkoh, B.A.; Ivan, C.; Mishra, B.M.; Rashid, A.; Calin, G.A.; Luthra, R.; Hamilton, S.R. Complex patterns of altered microRNA expression during the adenoma-adenocarcinoma sequence for microsatellite-stable colorectal cancer. Clin. Cancer Res. 2011, 17, 7283-7293. [CrossRef] [PubMed]

68. Liu, G.; Li, B. Role of miRNA in transformation from normal tissue to colorectal adenoma and cancer. J. Cancer Res. Ther. 2019, 15, 278-285. [PubMed]

69. Yin, Y.; Song, M.; Gu, B.; Qi, X.; Hu, Y.; Feng, Y.; Liu, H.; Zhou, L.; Bian, Z.; Zhang, J.; et al. Systematic analysis of key miRNAs and related signaling pathways in colorectal tumorigenesis. Gene 2016, 578, 177-184. [CrossRef]

70. Uratani, R.; Toiyama, Y.; Kitajima, T.; Kawamura, M.; Hiro, J.; Kobayashi, M.; Tanaka, K.; Inoue, Y.; Mohri, Y.; Mori, T.; et al. Diagnostic potential of cell-free and exosomal microRNAs in the identification of patients with high-risk colorectal adenomas. PLoS ONE 2016, 11, e0160722. [CrossRef] 
71. Imaoka, H.; Toiyama, Y.; Fujikawa, H.; Hiro, J.; Saigusa, S.; Tanaka, K.; Inoue, Y.; Mohir, Y.; Kato, T.; Toden, S.; et al. Circulating microRNA-1290 as a novel diagnostic and prognostic biomarker in human colorectal cancer. Ann. Oncol. 2016, 27, 1879-1886. [CrossRef] [PubMed]

72. Ho, G.Y.; Jung, H.J.; Schoen, R.E.; Wang, T.; Lin, J.; Williams, Z.; Weissfeld, J.L.; Park, J.Y.; Loudig, O.; Suh, Y. Differential expression of circulating microRNAs according to severity of colorectal neoplasia. Transl. Res. 2015, 166, 225-232. [CrossRef] [PubMed]

73. De Groen, F.L.; Timmer, L.M.; Menezes, R.X.; Diosdado, B.; Hooijberg, E.; Meijer, G.A.; Steenbergen, R.D.M.; Carvalho, B. Oncogenic role of miR-15a-3p in 13q amplicon-driven colorectal adenoma-to-carcinoma progression. PLoS ONE 2015, 10, e0132495.

74. Wu, C.W.; Ng, S.C.; Dong, Y.; Tian, L.; Ng, S.S.; Leung, W.W.; Law, W.T.; Yau, T.O.; Leung Chan, K.F.; Yiu Sung, J.J.; et al. Identification of microRNA-135b in stool as a potential noninvasive biomarker for colorectal cancer and adenoma. Clin. Cancer Res. 2014, 20, 2994-3002. [CrossRef] [PubMed]

75. Wu, C.W.; Ng, S.S.; Dong, Y.J.; Ng, S.C.; Leung, W.W.; Lee, C.W.; Wong, Y.N.; Chan, F.K.L.; Yu, J.; Sung, J.J.Y. Detection of miR-92a and miR-21 in stool samples as potential screening biomarkers for colorectal cancer and polyps. Gut 2012, 61, 739-745. [CrossRef] [PubMed]

76. Tsikitis, V.L.; Potter, A.; Mori, M.; Buckmeier, J.A.; Preece, C.R.; Harrington, C.A.; Bartley, A.N.; Bhattacharyya, A.K.; Hamilton, S.R.; Lance, M.P.; et al. MicroRNA signatures of colonic polyps on screening and histology. Cancer Prev. Res. 2016, 9, 942-949. [CrossRef]

77. Tadano, T.; Kakuta, Y.; Hamada, S.; Shimodaira, Y.; Kuroha, M.; Kawakami, Y.; Kimura, T.; Shiga, H.; Endo, K.; Masamune, A.; et al. MicroRNA-320 family is downregulated in colorectal adenoma and affects tumor proliferation by targeting CDK6. World J. Gastrointest. Oncol. 2016, 8, 532-542. [CrossRef]

78. Chen, T.; Cai, S.L.; Li, J.; Qi, Z.P.; Li, X.Q.; Ye, L.C.; Xie, X.F.; Hou, Y.Y.; Yao, L.Q.; Xu, M.D.; et al. Mecp2-mediated epigenetic silencing of miR-137 contributes to colorectal adenoma-carcinoma sequence and tumor progression via relieving the suppression of c-met. Sci. Rep. 2017, 7, 44543. [CrossRef]

79. Hibino, Y.; Sakamoto, N.; Naito, Y.; Goto, K.; Oo, H.Z.; Sentani, K.; Hinoi, T.; Ohdan, H.; Oue, N.; Yasui, W. Significance of miR-148a in colorectal neoplasia: Downregulation of miR-148a contributes to the carcinogenesis and cell invasion of colorectal cancer. Pathobiology 2015, 82, 233-241. [CrossRef]

80. Fang, Z.; Tang, J.; Bai, Y.; Lin, H.; You, H.; Jin, H.; Lin, L.; You, P.; Li, J.; Dai, Z.; et al. Plasma levels of microRNA-24, microRNA-320a, and microRNA-423-5p are potential biomarkers for colorectal carcinoma. J. Exp. Clin. Cancer Res. 2015, 34, 86. [CrossRef]

81. Basso, D.; Padoan, A.; Laufer, T.; Aneloni, V.; Moz, S.; Schroers, H.; Pelloso, M.; Saiz, A.; Krapp, M.; Fogar, P.; et al. Relevance of preanalytical blood management on the emerging cardiovascular protein biomarkers TWEAK and HMGB1 and on miRNA serum and plasma profiling. Clin. Biochem. 2017, 50, 186-193. [CrossRef] [PubMed]

82. Sourvinou, I.S.; Markou, A.; Lianidou, E.S. Quantification of circulating miRNAs in plasma: Effect of preanalytical and analytical parameters on their isolation and stability. J. Mol. Diagn. 2013, 15, 827-834. [CrossRef] [PubMed]

83. Terrinoni, A.; Calabrese, C.; Basso, D.; Aita, A.; Caporali, S.; Plebani, M.; Bernardini, S. The circulating miRNAs as diagnostic and prognostic markers. Clin. Chem. Lab. Med. 2019, 57, 932-953. [CrossRef]

84. Wang, H.; Peng, R.; Wang, J.; Qin, Z.; Xue, L. Circulating microRNAs as potential cancer biomarkers: The advantage and disadvantage. Clin. Epigenetics 2018, 10, 59. [CrossRef]

85. Kirschner, M.B.; Kao, S.C.; Edelman, J.J.; Armstrong, N.J.; Vallely, M.P.; van Zandwijk, N.; Reid, G. Haemolysis during sample preparation alters microRNA content of plasma. PLOS ONE 2011, 6, e24145. [CrossRef] [PubMed]

86. Cheng, H.H.; Yi, H.S.; Kim, Y.; Kroh, E.M.; Chien, J.W.; Eaton, K.D.; Goodman, M.T.; Tait, J.F.; Tewari, M.; Pritchard, C.C. Plasma processing conditions substantially influence circulating microRNA biomarker levels. PLoS ONE 2013, 8, 1-11. [CrossRef] [PubMed]

87. Healy, N.A.; Heneghan, H.M.; Miller, N.; Osborne, C.K.; Schiff, R.; Kerin, M.J. Systemic mirnas as potential biomarkers for malignancy. Int. J. Cancer 2012, 131, 2215-2222. [CrossRef]

88. Kanaan, Z.; Roberts, H.; Eichenberger, M.R.; Billeter, A.; Ocheretner, G.; Pan, J.; Rai, S.N.; Jorden, J.; Williford, A.; Galandiuk, S. A plasma microRNA panel for detection of colorectal adenomas: A step toward more precise screening for colorectal cancer. Ann. Surg. 2013, 258, 400-408. [CrossRef]

89. Giráldez, M.D.; Lozano, J.J.; Ramírez, G.; Hijona, E.; Bujanda, L.; Castells, A.; Gironella, M. Circulating microRNAs as biomarkers of colorectal cancer: Results from a genome-wide profiling and validation study. Clin. Gastroenterol. Hepatol. 2013, 11, 681-688. [CrossRef]

90. Wang, R.; Wen, H.; Xu, Y.; Chen, Q.; Luo, Y.; Lin, Y.; Luo, Y.; Xu, A. Circulating microRNAs as a novel class of diagnostic biomarkers in gastrointestinal tumors detection: A meta-analysis based on 42 articles. PLoS ONE 2014, 9, e113401. [CrossRef]

91. Slaby, O. Non-coding RNAs as biomarkers for colorectal cancer screening and early detection. Adv. Exp. Med. Biol. 2016, 937, 153-170. [PubMed]

92. Carter, J.V.; Galbraith, N.J.; Yang, D.; Burton, J.F.; Walker, S.P.; Galandiuk, S. Blood-based microRNAs as biomarkers for the diagnosis of colorectal cancer: A systematic review and meta-analysis. Br. J. Cancer 2017, 116, 762-774. [CrossRef] 
93. Chen, B.; Xia, Z.; Deng, Y.N.; Yang, Y.; Zhang, P.; Zhu, H.; Xu, N.; Liang, S. Emerging microRNA biomarkers for colorectal cancer diagnosis and prognosis. Open Biol. 2019, 9, 180212. [CrossRef] [PubMed]

94. Sabry, D.; El-Deek, S.E.M.; Maher, M.; El-Baz, M.A.H.; El-Bader, H.M.; Amer, E.; Hassan, E.A.; Fathy, W.; El-Deek, H.E.M. Role of miRNA-210, miRNA-21 and miRNA-126 as diagnostic biomarkers in colorectal carcinoma: Impact of HIF-1 $\alpha$-VEGF signaling pathway. Mol. Cell Biochem. 2019, 454, 177-189. [CrossRef]

95. Ng, L.; Wan, T.M.; Man, J.H.; Chow, A.K.; Iyer, D.; Chen, G.; Yau, T.C.; Lo, O.S.; Foo, D.C.; Poon, J.T.; et al. Identification of serum miR-139-3p as a non-invasive biomarker for colorectal cancer. Oncotarget 2017, 8, 27393-27400. [CrossRef]

96. Wang, P.; He, X. Current research on circular RNAs associated with colorectal cancer. Scand. J. Gastroenterol. 2017, 52, 1203-1210. [CrossRef] [PubMed]

97. Liu, X.; Xu, T.; Hu, X.; Chen, X.; Zeng, K.; Sun, L.; Wang, S. Elevated circulating miR-182 acts as a diagnostic biomarker for early colorectal cancer. Cancer Manag. Res. 2018, 10, 857-865. [CrossRef]

98. Bilegsaikham, E.; Liu, H.N.; Shen, X.Z.; Liu, T.T. Circulating miR-338-5p is a potential diagnostic biomarker in colorectal cancer. J. Dig. Dis. 2018, 19, 404-410. [CrossRef] [PubMed]

99. Krawczyk, P.; Powrózek, T.; Olesiński, T.; Dmitruk, A.; Dziwota, J.; Kowalski, D.; Milanowski, J. Evaluation of miR-506 and miR-4316 expression in early and non-invasive diagnosis of colorectal cancer. Int. J. Color. Dis. 2017, 32, 1057-1060. [CrossRef]

100. Nonaka, R.; Miyake, Y.; Hata, T.; Kagawa, Y.; Kato, T.; Osawa, H.; Nishimura, J.; Ikenaga, M.; Murata, K.; Uemura, M.; et al. Circulating miR-103 and miR-720 as novel serum biomarkers for patients with colorectal cancer. Int. J. Oncol. 2015, 47, 1097-1102. [CrossRef]

101. Sarlinova, M.; Halasa, M.; Mistuna, D.; Musak, L.; Iliev, R.; Slaby, O.; Mazuchova, J.; Valentova, V.; Plank, L.; Halasova, E. miR-21, miR-221 and miR-150 are deregulated in peripheral blood of patients with colorectal cancer. Anticancer Res. 2016, 36, 5449-5454. [CrossRef] [PubMed]

102. Chang, P.Y.; Chen, C.C.; Chang, Y.S.; Tsai, W.S.; You, J.F.; Lin, G.P.; Chen, T.W.; Chen, J.S.; Chan, E.C. MicroRNA-223 and microRNA-92a in stool and plasma samples act as complementary biomarkers to increase colorectal cancer detection. Oncotarget 2016, 7, 10663-10675. [CrossRef] [PubMed]

103. Nikolaou, S.; Qiu, S.; Fiorentino, F.; Rasheed, S.; Tekkis, P.; Kontovounisios, C. Systematic review of blood diagnostic markers in colorectal cancer. Tech. Coloproctol. 2018, 22, 481-498. [CrossRef] [PubMed]

104. Liu, X.; Xu, X.; Pan, B.; He, B.; Chen, X.; Zeng, K.; Xu, M.; Pan, Y.; Sun, H.; Xu, T.; et al. Circulating miR-1290 and miR-320d as novel diagnostic biomarkers of human colorectal cancer. J. Cancer 2019, 10, 43-50. [CrossRef] [PubMed]

105. Wikberg, M.L.; Myte, R.; Palmqvist, R.; van Guelpen, B.; Ljuslinder, I. Plasma miRNA can detect colorectal cancer, but how early? Cancer Med. 2018, 7, 1697-1705. [CrossRef]

106. Herreros-Villanueva, M.; Duran-Sanchon, S.; Martin, A.C.; Perez-Palacios, R.; Vila-Navarro, E.; Marcuello, M.; Diaz-Centeno, M.; Cubiella, J.; Diez, M.S.; Bujanda, L.; et al. Plasma microRNA signature validation for early detection of colorectal cancer. Clin. Transl. Gastroenterol. 2019, 10, e00003. [CrossRef]

107. Zhang, H.; Zhu, M.; Shan, X.; Zhou, X.; Wang, T.; Zhang, J.; Tao, J.; Cheng, W.; Chen, G.; Li, J.; et al. A panel of seven-miRNA signature in plasma as potential biomarker for colorectal cancer diagnosis. Gene 2019, 687, 246-254. [CrossRef]

108. Tian, J.; Xi, X.; Wang, J.; Yu, J.; Huang, Q.; Ma, R.; Zhang, X.; Li, H.; Wang, L. CircRNA hsa_circ_0004585 as a potential biomarker for colorectal cancer. Cancer Manag. Res. 2019, 11, 5413-5423. [CrossRef]

109. Karimi, N.; Hosseinpour Feizi, M.A.; Safarazadeh, R.; Hashemzadeh, S.; Baradaran, B.; Shokouhi, B.; Teimourian, S. Serum overexpression of miR-301a and miR-23a in patients with colorectal cancer. J. Chin. Med. Assoc. 2019, 82, 215-220. [CrossRef]

110. Tan, Y.; Lin, J.J.; Yang, X.F.; Gou, D.M.; Wu, F.L.; Li, F.R.; Yu, X.F. A panel of three plasma microRNAs for colorectal cancer diagnosis. Cancer Epidemiol. 2019, 60, 67-76. [CrossRef]

111. Maminezdah, H.; Ghanadian, S.; Pakravan, K.; Razmara, E.; Rouhollah, F.; Mossahebi-Mohammadi, M.; Babashah, S. A panel of six-circulating miRNA signature in serum and its potential diagnostic value in colorectal cancer. Life Sci. 2020, $258,118226$. [CrossRef] [PubMed]

112. Liu, W.; Yang, D.; Chen, L.; Liu, Q.; Wang, W.; Yang, Z.; Shang, A.; Quan, W.; Li, D. Plasma exosomal miRNA-139-3p is a novel biomarker of colorectal cancer. J. Cancer 2020, 11, 4899-4906. [CrossRef] [PubMed]

113. Jin, X.H.; Lu, S.; Wang, A.F. Expression and clinical significance of miR-4516 and miR-21-5p in serum of patients with colorectal cancer. BMC Cancer 2020, 20, 241. [CrossRef] [PubMed]

114. Mun-Kar Ng, J.; Yu, J. Promoter hypermethylation of tumour suppressor genes as potential biomarkers in colorectal cancer. Int. J. Mol. Sci. 2015, 16, 2472-2496. [CrossRef] [PubMed]

115. Song, L.; Li, Y. SEPT9: A specific circulating biomarker for colorectal cancer. Adv. Clin. Chem. 2015, 72, 171-204.

116. Song, L.; Jia, J.; Peng, X.; Xiao, W.; Li, Y. The performance of the SEPT9 gene methylation assay and a comparison with other CRC screening tests: A meta-analysis. Sci. Rep. 2017, 7, 3032. [CrossRef]

117. Hu, J.; Hu, B.; Gui, Y.C.; Tan, Z.B.; Xu, J.W. Diagnostic value and clinical significance of methylated SEPT9 for colorectal cancer: A meta-analysis. Med. Sci. Monit. 2019, 25, 5813-5822. [CrossRef]

118. Hariharan, R.; Jenkins, M. Utility of the methylated SEPT9 test for the early detection of colorectal cancer: A systematic review and meta-analysis of diagnostic test accuracy. BMJ Open Gastroenterol. 2020, 7, e000355. [CrossRef]

119. Wang, Y.; Chen, P.M.; Liu, R.B. Advance in plasma SEPT9 gene methylation assay for colorectal cancer early detection. World J. Gastrointest. Oncol. 2018, 10, 15-22. [CrossRef] 
120. Tepus, M.; On Yau, T. Non-invasive colorectal cancer screening: An overview. Gastrointest. Tumors 2020, 7, 62-73. [CrossRef]

121. Song, L.; Li, Y.; Jia, J.; Zhou, G.; Wang, J.; Kang, Q.; Jin, P.; Sheng, J.; Cai, G.; Cai, S.; et al. Algorithm optimization in methylation detection with multiple RT-qPCR. PLoS ONE 2016, 11, e0163333. [CrossRef]

122. Church, T.R.; Wandell, M.; Lofton-Day, C.; Mongin, S.J.; Burger, M.; Payne, S.R.; Castaños-Vélez, E.; Blumenstein, B.A.; Rösch, T.; Osborn, N.; et al. Prospective evaluation of methylated SEPT9 in plasma for detection of asymptomatic colorectal cancer. Gut 2014, 63, 317-325. [CrossRef]

123. Bibbins-Domingo, K.; Grossman, D.C.; Curry, S.J.; Davidson, K.W.; Epling, J.W., Jr.; García, F.A.R.; Gillman, M.W.; Harper, D.M.; Kemper, A.R.; Krist, A.H.; et al. US preventive services task force screening for colorectal cancer: US preventive services task force recommendation statement. JAMA 2016, 315, 2564-2575.

124. Grützmann, R.; Molnar, B.; Pilarsky, C.; Habermann, J.K.; Schalg, P.M.; Saeger, H.D.; Miehlke, S.; Stolz, T.; Model, F.; Roblick, U.J.; et al. Sensitive detection of colorectal cancer in peripheral blood by septin 9 DNA methylation assay. PLoS ONE 2008, 3, e3759. [CrossRef]

125. Lofton-Day, C.; Model, F.; Devos, T.; Tetzner, R.; Distler, J.; Schuster, M.; Song, X.; Lesche, R.; Liebenberg, V.; Ebert, M.; et al. DNA methylation biomarkers for blood based colorectal cancer screening. Clin. Chem. 2008, 54, 414-423. [CrossRef]

126. deVos, T.; Tetzner, R.; Model, F.; Weiss, G.; Schuster, M.; Distler, J.; Steiger, K.V.; Grutzmann, R.; Pilarsky, C.; Habermann, J.K.; et al. Circulating methylated SEPT9 DNA in plasma is a biomarker for colorectal cancer. Clin. Chem. 2009, 55, 1337-1346. [CrossRef]

127. He, Q.; Chen, H.Y.; Bai, E.Q.; Luo, Y.X.; Fu, R.J.; He, Y.S.; Jiang, J.; Wang, H.Q. Development of a multiplex MethyLight assay for the detection of multigene methylation in human colorectal cancer. Cancer Genet. Cytogenet. 2010, 202, 1-10. [CrossRef]

128. Tanzer, M.; Balluff, B.; Distler, J.; Hale, K.; Leodolter, A.; Rocken, C.; Molnar, B.; Schmid, R.; Lofton-Day, C.; Schuster, T.; et al Performance of epigenetic markers SEPT9 and ALX4 in plasma for detection of colorectal precancerous lesions. PLoS ONE 2010, 5, e9061. [CrossRef]

129. Herbst, A.; Rahmig, K.; Stieber, P.; Phillipe, A.; Jung, A.; Ofner, A.; Crispin, A.; Neumann, J.; Lamerz, R.; Kolligs, F.T. Methylation of NEUROG1 in serum is a sensitive marker for the detection of early colorectal cancer. Am. J. Gastroenterol. 2011, 106, 1110-1118. [CrossRef]

130. Warren, J.D.; Xiong, W.; Bunker, A.M.; Vaughn, C.P.; Furtado, L.V.; Roberts, W.L.; Fang, J.C.; Samowitz, W.S.; Heichman, K.A. Septin 9 methylated DNA is a sensitive and specific blood test for colorectal cancer. BMC Med. 2011, 9, 133. [CrossRef]

131. Tóth, K.; Sipos, F.; Kalmár, A.; Patai, A.V.; Wichmann, B.; Stoehr, R.; Golcher, H.; Schellerer, V.; Tulassay, Z.; Molnár, B. Detection of methylated SEPT9 in plasma is a reliable screening method for both left- and right-sided colon cancers. PLoS ONE 2012, 7, e46000. [CrossRef]

132. Ahlquist, D.A.; Taylor, W.R.; Mahoney, D.W.; Zou, H.; Domanico, M.; Thibodeau, S.N.; boardman, L.A.; Berger, B.M.; Lidgard, G.P. The stool DNA test is more accurate than the plasma septin 9 test in detecting colorectal neoplasia. Clin. Gastroenterol. Hepatol. 2012, 10, 272-277. [CrossRef]

133. Lee, H.S.; Hwang, S.M.; Kim, T.S.; Kim, D.W.; Park, D.J.; Kang, S.B.; Kim, H.H.; Park, K.U. Circulating methylated septin 9 nucleic acid in the plasma of patients with gastrointestinal cancer in the stomach and colon. Transl. Oncol. 2013, 6, 290-294. [CrossRef]

134. Potter, N.T.; Hurban, P.; White, M.N.; Whitlock, K.D.; Lofton-Day, C.E.; Tetzner, R.; Koenig, T.; Quigley, N.B.; Weiss, G. Validation of a real-time PCR-based qualitative assay for the detection of methylated SEPT9 DNA in human plasma. Clin. Chem. 2014, 60, 1183-1191. [CrossRef]

135. Su, X.L.; Wang, Y.F.; Li, S.J.; Zhang, F.; Cui, H.W. High methylation of the SEPT9 gene in Chinese colorectal cancer patients. Genet. Mol. Res. 2014, 13, 2513-2520. [CrossRef]

136. Johnson, D.A.; Barclay, R.L.; Mergener, K.; Weiss, G.; König, T.; Beck, J.; Potter, N.T. Plasma Septin9 versus fecal immunochemical testing for colorectal cancer screening: A prospective multicenter study. PLoS ONE 2014, 9, e98238. [CrossRef]

137. Jin, P.; Kang, Q.; Wang, X.; Yang, L.; Yu, Y.; Li, N.; He, Y.Q.; Han, X.; Hang, J.; Zhang, J.; et al. Performance of a second generation methylated SEPT9 test in detecting colorectal neoplasm. J. Gastroenterol. Hepatol. 2015, 30, 830-833. [CrossRef]

138. Kang, Q.; Jin, P.; Yang, L.; Wang, X.; An, H.; Liu, L.; Li, N.; Sheng, J. Significance of Septin9 gene methylation detection of plasma circulation DNA in colorectal cancer screening. Zhonghua Yi Xue Za Zhi 2014, 94, 3839-3841. (In Chenese)

139. Toth, K.; Wasserkort, R.; Sipos, F.; Kalmar, A.; Wichmann, B.; Leiszter, K.; Valcz, G.; Juhasz, M.; Miheller, P.; Patai, A.V.; et al. Detection of methylated septin 9 in tissue and plasma of colorectal patients with neoplasia and the relationship to the amount of circulating cell-free DNA. PLoS ONE 2014, 9, e115415. [CrossRef]

140. Ørntoft, M.B.; Nielsen, H.J.; Ørntoft, T.F.; Andersen, C.L.; Danish Study Group on Early Detection of Colorectal Cancer. Performance of the colorectal cancer screening marker Sept 9 is influenced by age, diabetes and arthritis: A nested case-control study. BMC Cancer 2015, 15, 819. [CrossRef]

141. Behrouz Sharif, S.; Hashemzadeh, S.; Mousavi Ardehaie, R.; Eftekharsadat, A.; Ghojazadeh, M.; Mehrtash, A.H.; Estiar, M.A.; Teimoori-Toolabi, L.; Sakhinia, E. Detection of aberrant methylated SEPT9 and NTRK3 genes in sporadic colorectal cancer patients as a potential diagnostic biomarker. Oncol. Lett. 2016, 12, 5335-5343. [CrossRef] [PubMed]

142. Wu, D.; Zhou, G.; Jin, P.; Zhu, J.; Li, S.; Wu, Q.; Wang, G.; Sheng, J.; Wang, J.; Song, L.; et al. Detection of colorectal cancer using a simplified SEPT9 gene methylation assay is a reliable method for opportunistic screening. J. Mol. Diagn. 2016, 18, 535-545. [CrossRef] 
143. Nian, J.; Sun, X.; Ming, S.; Yan, C.; Ma, Y.; Feng, Y.; Yang, L.; Yu, M.; Zhang, G.; Wang, X. Diagnostic accuracy of methylated SEPT9 for blood-based colorectal cancer detection: A systematic review and meta-analysis. Clin. Transl. Gastroenterol. 2017, 8 , e216. [CrossRef] [PubMed]

144. Fu, B.; Yan, P.; Zhang, S.; Lu, Y.; Pan, L.; Tang, W.; Chen, S.; Chen, S.; Zhang, A.; Liu, W. Cell-free circulating methylated SEPT9 for noninvasive diagnosis and monitoring of colorectal cancer. Dis. Markers 2018, 2018, 6437104. [CrossRef]

145. Xie, L.; Jiang, X.; Li, Q.; Su, Z.; Quan, W.; Duan, W.; Li, D.; Che, T. Diagnostic value of methylated septin9 for colorectal cancer detection. Front. Oncol. 2018, 8, 247-254. [CrossRef]

146. Arellano, M.L.; Garcia-Arranz, M.; Ruiz, R.; Olivera, R.; Magallares, S.; Olmedillas-Lopez, S.; Valdez-Sanchez, T.; Guadalajara, H.; Garcia-Olmo, D. A first step to a biomarker of curative surgery in colorectal cancer by liquid biopsy of methylated septin 9 gene. Dis. Markers 2020, 2020, 9761406. [CrossRef]

147. Liu, Y.; Zhao, G.; Miao, J.; Li, H.; Ma, Y.; Liu, X.; Li, S.; Zhu, Y.; Xiong, S.; Zheng, M.; et al. Performance comparison between plasma and stool methylated SEPT9 tests for detecting colorectal cancer. Front. Genet. 2020, 11, 324. [CrossRef]

148. Dong, L.; Lin, W.; Qi, P.; Xu, M.D.; Wu, X.; Ni, S.; Huang, D.; Weng, W.W.; Tan, C.; Sheng, W.; et al. Circulating long RNAs in serum extracellular vesicles: Their characterization and potential application as biomarkers for diagnosis of colorectal cancer. Cancer Epidemiol. Biomark. Prev. 2016, 25, 1158-1166. [CrossRef]

149. Ferracin, M.; Lupini, L.; Mangolini, A.; Negrini, M. Circulating non-coding RNA as biomarkers in colorectal cancer. Adv. Exp. Med. Biol. 2016, 937, 171-181.

150. Ragusa, M.; Barbagallo, C.; Statello, L.; Condorelli, A.G.; Battaglia, R.; Tamburello, L.; Barbagallo, D.; Di Pietro, C.; Purrello, M. Non-coding landscapes of colorectal cancer. World J. Gastroenterol. 2015, 21, 11709-11739. [CrossRef]

151. Manzat Saplacan, R.M.; Mircea, P.A.; Balacescu, L.; Balacescu, O. MicroRNAs as non-invasive screening biomarkers of colorectal cancer. Clujul Med. 2015, 88, 453-456. [CrossRef] [PubMed]

152. Mercer, T.R.; Dinger, M.E.; Mattick, J.S. Long non-coding RNAs: Insights into functions. Nat. Rev. Genet. 2009, 10, 155-159. [CrossRef]

153. Hüttenhofer, A.; Vogel, J. Experimental approaches to identify non-coding RNAs. Nucleic Acids Res. 2006, 34, 635-646. [CrossRef]

154. Xu, M.D.; Qi, P.; Du, X. Long non-coding RNAs in colorectal cancer: Implications for pathogenesis and clinical application. Mod. Pathol. 2014, 27, 1310-1320. [CrossRef]

155. Sole, C.; Arnaiz, E.; Manterola, L.; Otaegui, D.; Lawrie, C.H. The circulating transcriptome as a source of cancer liquid biopsy biomarkers. Semin. Cancer Biol. 2019, 58, 100-108. [CrossRef]

156. Galamb, O.; Bartak, B.K.; Kalmar, A.; Nagy, Z.B.; Szigeti, K.A.; Tulassay, Z.; Igaz, P.; Molnar, B. Diagnostic and prognostic potential of tissue and circulating long non-coding RNAs in colorectal tumors. World J. Gastroenterol. 2019, 25, 5026-5048. [CrossRef]

157. Ma, Y.; Yang, Y.; Wang, F.; Moyer, M.P.; Wei, Q.; Zhang, P.; Yang, Z.; Liu, W.; Zhang, H.; Chen, N.; et al. Long non-coding RNA CCAL regulates colorectal cancer progression by activating Wnt/ $\beta$-catenin signalling pathway via suppression of activator protein $2 \alpha$. Gut 2016, 65, 1494-1504. [CrossRef] [PubMed]

158. Ji, Q.; Liu, X.; Fu, X.; Zhang, L.; Sui, H.; Zhou, L.; Sun, J.; Cai, J.; Qin, J.; Ren, J.; et al. Resveratrol inhibits invasion and metastasis of colorectal cancer cells via MALAT1 mediated Wnt/ $\beta$-catenin signal pathway. PLoS ONE 2013, 8, e78700. [CrossRef]

159. Yang, P.; Yang, Y.; An, W.; Xu, J.; Zhang, G.; Jie, J.; Zhang, Q. The long noncoding RNA-ROR promotes the resistance of radiotherapy for human colorectal cancer cells by targeting the p53/miR-145 pathway. J. Gastroenterol. Hepatol. 2017, 32, 837-845. [CrossRef]

160. Lo, Y.M. Circulating nucleic acids in plasma and serum: An overview. Ann. N. Y. Acad. Sci. 2001, 945, 1-7. [CrossRef] [PubMed]

161. Shi, T.; Gao, G.; Cao, Y. Long noncoding RNAs as novel biomarkers have a promising future in cancer diagnostics. Dis. Markers 2016, 2016, 9085195. [CrossRef]

162. Qi, P.; Zhou, X.Y.; Du, X. Circulating long non-coding RNAs in cancer: Current status and future perspectives. Mol. Cancer 2016, 15, 39. [CrossRef] [PubMed]

163. Xie, H.; Ma, H.; Zhou, D. Plasma HULC as a promising novel biomarker for the detection of hepatocellular carcinoma. BioMed. Res. Int. 2013, 2013, 136106. [CrossRef]

164. Revenfeld, A.L.; Baek, R.; Nielsen, M.H.; Stensballe, A.; Varming, K.; Jorgensen, M. Diagnostic and prognostic potential of extracellular vesicles in peripheral blood. Clin. Ther. 2014, 36, 830-846. [CrossRef]

165. Mathieu, M.; Martin-Jaular, L.; Lavieu, G.; Théry, C. Specificities of secretion and uptake of exosomes and other extracellular vesicles for cell-to-cell communication. Nat. Cell Biol. 2019, 21, 9-17. [CrossRef]

166. Svoboda, M.; Slyskova, J.; Schneiderova, M.; Makovicky, P.; Bielik, L.; Levy, M.; Lipska, L.; Hemmelova, B.; Kala, Z.; Protivankova, M.; et al. HOTAIR long non-coding RNA is a negative prognostic factor not only in primary tumors, but also in the blood of colorectal cancer patients. Carcinogenesis 2014, 35, 1510-1515. [CrossRef]

167. Van Niel, G.; Porto-Carreiro, I.; Simoes, S.; Raposo, G. Exosomes: A common pathway for a specialized function. J. Biochem. 2006, 140, 13-21. [CrossRef]

168. Fang, T.; Lv, H.; Lv, G.; Li, T.; Wang, C.; Han, Q.; Yu, L.; Su, B.; Guo, L.; Huang, S.; et al. Tumor-derived exosomal miR-1247-3p induces cancer-associated fibroblast activation to foster lung metastasis of liver cancer. Nat. Commun. 2018, 9, 191. [CrossRef] [PubMed]

169. Kalluri, R. The biology and function of exosomes in cancer. J. Clin. Investig. 2016, 126, 1208-1215. [CrossRef] [PubMed] 
170. Shao, Y.; Shen, Y.; Chen, T.; Xu, F.; Chen, X.; Zheng, S. The functions and clinical applications of tumorderived exosomes. Oncotarget 2016, 7, 60736-66075. [CrossRef]

171. Baassiri, A.; Nassar, F.; Mukherji, D.; Shamseddine, A.; Nasr, R.; Temraz, S. Exosomal non coding RNA in LIQUID biopsies as a promising biomarker for colorectal cancer. Int. J. Mol. Sci. 2020, 21, 1398. [CrossRef]

172. Benes, V.; Castoldi, M. Expression profiling of microRNA using real-time quantitative PCR, how to use it and what is available. Methods 2010, 50, 244-249. [CrossRef]

173. Duran-Sanchon, S.; Vila-Navarro, E.; Marcuello, M.; Lozano, J.J.; Munoz, J.; Cubiella, J.; Diez, M.S.; Bujanda, L.; Lanas, A.; Jover, R.; et al. Validation of miR-1228-3p as housekeeping for microRNA analysis in liquid biopsies from colorectal cancer patients. Biomolecules 2019, 10, 16. [CrossRef] [PubMed]

174. Zhao, W.; Song, M.; Zhang, J.; Kuerban, M.; Wang, H. Combined identification of long non-coding RNA CCAT1 and HOTAIR in serum as an effective screening for colorectal carcinoma. Int. J. Clin. Exp. Pathol. 2015, 8, 14131-14140.

175. Wang, C.; Yu, J.; Han, Y.; Li, L.; Li, J.; Li, T.; Qi, P. Long non-coding RNAs LOC285194, RP11-462C24.1 and Nbla12061 in serum provide a new approach for distinguishing patients with colorectal cancer from healthy controls. Oncotarget 2016, 7, 70769-70778. [CrossRef]

176. Dai, M.; Chen, X.; Mo, S.; Li, J.; Huang, Z.; Huang, S.; Xu, J.; He, B.; Zou, Y.; Chen, J.; et al. Meta-signature LncRNAs serve as novel biomarkers for colorectal cancer: Integrated bioinformatics analysis, experimental validation and diagnostic evaluation. Sci. Rep. 2017, 7, 46572. [CrossRef] [PubMed]

177. Barbagallo, C.; Brex, D.; Caponnetto, A.; Cirnigliaro, M.; Scalia, M.; Magnano, A.; Caltabiano, R.; Barbagallo, D.; Biondi, A.; Cappellani, A.; et al. LncRNA UCA1, upregulated in CRC biopsies and downregulated in serum exosomes, controls mRNA expression by RNA-RNA interactions. Mol. Ther. Nucleic Acids 2018, 12, 229-241. [CrossRef]

178. Liu, H.; Ye, D.; Chen, A.; Tan, D.; Zhang, W.; Jiang, W.; Wang, M.; Zhang, X. A pilot study of new promising non-coding RNA diagnostic biomarkers for early-stage colorectal cancers. Clin. Chem. Lab. Med. 2019, 57, 1073-1083. [CrossRef] [PubMed]

179. Abedini, P.; Fattahi, A.; Agah, S.; Talebi, A.; Beygi, A.H.; Amini, S.M.; Mirzaei, A.; Akbari, A. Expression analysis of circulating plasma long noncoding RNAs in colorectal cancer: The relevance of lncRNAs ATB and CCAT1 as potential clinical hallmarks. $J$. Cell. Physiol. 2019, 234, 22028-22033. [CrossRef] [PubMed]

180. Yan, L.; Zhao, W.; Yu, H.; Wang, Y.; Liu, Y.; Xie, C. A comprehensive meta-analysis of microRNAs for predicting colorectal cancer. Medicine 2016, 95, e2738. [CrossRef]

181. He, Y.; Lin, J.; Kong, D.; Huang, M.; Xu, C.; Kim, T.K.; Etheridge, A.; Luo, Y.; Ding, Y.; Wang, K. Current state of circulating microRNAs as cancer biomarkers. Clin. Chem. 2015, 61, 1138-1155. [CrossRef]

182. Zeng, W.; Tu, Y.; Zhu, Y.; Wang, Z.; Li, C.; Lao, L.; Wu, G. Predictive power of circulating miRNAs in detecting colorectal cancer. Tumour Biol. 2015, 36, 2559-2567. [CrossRef]

183. Yu, H.; Rohan, T. Role of the insulin-like growth factor family in cancer development and progression. J. Natl. Cancer Inst. 2000, 92, 1472-1489. [CrossRef]

184. Pollak, M.N.; Schernhammer, E.S.; Hankinson, E. Insulin-like growth factors and neoplasia. Nat. Rev. Cancer 2004, 4, 505-518. [CrossRef]

185. Schoen, R.E.; Tangen, C.M.; Kuller, L.H.; Burke, G.L.; Cushman, M.; Tracy, R.P.; Dobs, A.; Savage, P.J. Increased blood glucose and insulin, body size, and incident colorectal cancer. J. Natl. Cancer Inst. 1999, 91, 1147-1154. [CrossRef]

186. Schütt, B.S.; Langkamp, M.; Rauschnabel, U.; Ranke, M.B.; Elmlinger, M.W. Integrin-mediated action of insulin-like growth factor binding protein-2 in tumor cells. J. Mol. Endocrinol. 2004, 32, 859-868. [CrossRef] [PubMed]

187. Hung, C.S.; Huang, C.Y.; Lee, C.H.; Chen, W.Y.; Huang, M.T.; Wei, P.L.; Chang, Y.J. IGFBP2 plays an important role in heat shock protein 27-mediated cancer progression and metastasis. Oncotarget 2017, 8, 54978-54992. [CrossRef] [PubMed]

188. Diehl, D.; Hessel, E.; Oesterle, D.; Renner-Muller, I.; Elmlinger, M.; Langhammer, M.; Hoeflich, A. IGFBP-2 overexpression reduces the appearance of dysplastic aberrant crypt foci and inhibits growth of adenomas in chemically induced colorectal carcinogenesis. Int. J. Cancer 2009, 124, 2220-2225. [CrossRef] [PubMed]

189. Renehan, A.G.; Jones, J.; Potten, C.S.; Shalet, S.M.; O’Dwyer, S.T. Elevated serum insulin-like growth factor (IGF)-II and IGF binding protein-2 in patients with colorectal cancer. Br. J. Cancer 2000, 83, 1344-1350. [CrossRef]

190. Demir, A.S.; Erdenen, F.; Muderrisoglu, C.; Toros, A.B.; Bektas, H.; Gelisgen, R.; Tabak, O.; Altunoglu, E.; Uzun, H.; Huq, G.E.E.; et al. Diagnostic and prognostic value of tumor M2-pyruvate kinase levels in patients with colorectal cancer. Turk. J. Gastroenterol. 2013, 24, 36-42. [CrossRef]

191. Hardt, P.D.; Ewald, N. Tumor M2 pyruvate kinase: A tumor marker and its clinical application in gastrointestinal malignancy. Expert Rev. Mol. Diagn. 2008, 8, 579-585. [CrossRef]

192. Hardt, P.D.; Toepler, M.; Ngoumou, B.; Rupp, J.; Kloer, H.U. Measurement of fecal pyruvate kinase type M2 (tumor M2PK) concentrations in patients with gastric cancer, colorectal cancer, colorectal adenomas and controls. Anticancer Res. 2003, 23, 851-853.

193. Haug, U.; Hundt, S.; Brenner, H. Sensitivity and specificity of faecal tumour M2 pyruvate kinase for detection of colorectal adenomas in a large screening study. Br. J. Cancer 2008, 99, 133-135. [CrossRef]

194. Koss, K.; Maxton, D.; Jankowski, J.A. Faecal dimeric M2 pyruvate kinase in colorectal cancer and polyps correlates with tumour staging and surgical intervention. Color. Dis. 2008, 10, 244-248. [CrossRef] [PubMed] 
195. Li, R.; Liu, J.; Xue, H.; Huang, G. Diagnostic value of fecal tumor M2-pyruvate kinase for CRC screening: A systematic review and meta-analysis. Int. J. Cancer 2012, 131, 1837-1845. [CrossRef] [PubMed]

196. Mulder, S.A.; van Leerdam, M.E.; van Vuuren, A.J.; Francke, J.; van Toorenenbergen, A.W.; Kuipers, E.J.; Ouwendijk, R.J.T. Tumor pyruvate kinase isoenzyme type M2 and immunochemical fecal occult blood test: Performance in screening for colorectal cancer. Eur. J. Gastroenterol. Hepatol. 2007, 19, 878-882. [CrossRef] [PubMed]

197. Shastri, Y.M.; Loitsch, S.; Hoepffner, N.; Povse, N.; Hanisch, E.; Rosch, W.; Mossner, J.; Stein, J.M. Comparison of an established simple office-based immunological FOBT with fecal tumor pyruvate kinase type M2 (M2-PK) for colorectal cancer screening: Prospective multicenter study. Am. J. Gastroenterol. 2008, 103, 1496-1504. [CrossRef]

198. Uppara, M.; Adaba, F.; Askari, A.; Clark, S.; Hanna, G.; Athanasiou, T.; Faiz, O. A systematic review and metaanalysis of the diagnostic accuracy of pyruvate kinase M2 isoenzymatic assay in diagnosing colorectal cancer. World J. Surg. Oncol. 2015, 13, 48. [CrossRef]

199. Sithambaram, S.; Hilmi, I.; Goh, K.L. The diagnostic accuracy of the M2 pyruvate kinase quick stool test-A rapid office based assay test for the detection of colorectal cancer. PLOS ONE 2015, 10, e0131616. [CrossRef]

200. Croix, B.S.; Rago, C.; Velculescu, V.; Traverso, G.; Romans, K.E.; Montgomery, E.; Lal, A.; Riggins, G.J.; Lengauer, C.; Vogelstein, B.; et al. Genes expressed in human tumor endothelium. Science 2000, 289, 1197-1202. [CrossRef]

201. Krupnik, V.E.; Sharp, J.D.; Jiang, C.; Robison, K.; Chickering, T.W.; Amaravadi, L.; Brown, D.E.; Guyot, D.; Mays, G.; Leiby, K.; et al. Functional and structural diversity of the human Dickkopf gene family. Gene 1999, 238, 301-313. [CrossRef]

202. Niehr, C. Function and biological roles of the Dickkopf family of WNT modulators. Oncogene 2006, 25, 7469-7481. [CrossRef]

203. Maehata, T.; Taniguchi, H.; Yamamoto, H.; Nosho, K.; Adachi, Y.; Miyamoto, N.; Miyamoto, C.; Akutsu, N.; Yamaoka, S.; Itoh, F. Transcriptional silencing of Dickkopf gene family by CpG island hypermethylation in human gastrointestinal cancer. World J. Gastroenterol. 2008, 14, 2702-2714. [CrossRef] [PubMed]

204. Sato, H.; Suzuki, H.; Toyota, M.; Nojima, M.; Maruyama, R.; Sasaki, S.; Takagi, H.; Sogabe, Y.; Sasaki, Y.; Idogawa, M.; et al. Frequent epigenetic inactivation of DICKKOPF family genes in human gastrointestinal tumors. Carcinogenesis 2007, 28, 2459-2466. [CrossRef]

205. Zitt, M.; Untergasser, G.; Amberger, A.; Moser, P.; Stadlmann, S.; Zitt, M.; Muller, H.M.; Muhlmann, G.; Perathoner, A.; Margreiter, R.; et al. Dickkopf-3 as a new potential marker for neoangiogenesis in colorectal cancer: Expression in cancer tissue and adjacent non-cancerous tissue. Dis. Markers 2008, 24, 101-109. [CrossRef] [PubMed]

206. Fung, K.Y.C.; Tabor, B.; Buckley, M.J.; Priebe, I.K.; Purins, L.; Pompeia, C.; Brierley, G.V.; Lockett, T.; Gibbs, P.; Tie, J.; et al. Blood-based protein biomarker panel for the detection of colorectal cancer. PLoS ONE 2015, 10, e0120425. [CrossRef]

207. Kawai, H.; Tomii, K.; Toyooka, S.; Yano, M.; Murakami, M.; Tsukuda, K.; Shimizu, N. Promoter methylation downregulates CDX2 expression in colorectal carcinomas. Oncol. Rep. 2005, 13, 547-551. [CrossRef] [PubMed]

208. Chen, L.; Wang, P.; Andrade, C.F.; Zhao, I.Y.; Dube, P.E.; Brubaker, P.L.; Liu, M.; Jin, T. PKA independent and cell type specific activation of the expression of caudal homeobox gene Cdx-2 by cyclic AMP. FEBS J. 2005, 272, 2746-2759. [CrossRef]

209. Zheng, J.; He, S.; Qi, J.; Wang, X.; Yu, J.; Wu, Y.; Gao, Q.; Wang, K.; Sun, X. Targeted CDX2 expression inhibits aggressive phenotypes of colon cancer cells in vitro and in vivo. Int. J. Oncol. 2017, 51, 478-488. [CrossRef] [PubMed]

210. Persad, S.; Troussard, A.A.; McPhee, T.R.; Mulholland, D.J.; Dedhar, S. Tumor suppressor PTEN inhibits nuclear accumulation of beta-catenin and T cell/lymphoid enhancer factor 1-mediated transcriptional activation. J. Cell Biol. 2001, 153, 1161-1174. [CrossRef]

211. Olsen, A.K.; Coskun, M.; Bzorek, M.; Kristensen, M.H.; Danielsen, E.T.; Jørgensen, S.; Olsen, J.; Engel, U.; Holck, S.; Troelsen, J.T. Regulation of APC and AXIN2 expression by intestinal tumor suppressor CDX2 in colon cancer cells. Carcinogenesis 2013, 34, 1361-1369. [CrossRef]

212. Toth, C.; Sukosd, F.; Valicsek, E.; Herpel, E.; Schirmacher, P.; Tiszlavicz, L. Loss of CDX2 gene expression is associated with DNA repair proteins and is a crucial member of the Wnt signaling pathway in liver metastasis of colorectal cancer. Oncol. Lett. 2018, 15, 3586-3593. [PubMed]

213. Wang, Y.; Li, Z.; Li, W.; Liu, S.; Han, B. Methylation of promoter region of CDX2 gene in colorectal cancer. Oncol. Lett. 2016, 12, 3229-3233. [CrossRef]

214. Asgari-Karchekani, S.; Karimian, M.; Mazoochi, T.; Taheri, M.A.; Khamehchian, T. CDX2 protein expression in colorectal cancer and its correlation with clinical and pathological characteristics, prognosis, and survival rate of patients. J. Gastrointest. Cancer 2020, 51, 844-849. [CrossRef] [PubMed]

215. Zhang, B.Y.; Jones, J.C.; Briggler, A.M.; Hubbard, J.M.; Kipp, B.R.; Sargent, D.J.; Dixon, J.G.; Grothey, A. Lack of caudal-type homeobox transcription factor 2 expression as a prognostic biomarker in metastatic colorectal cancer. Clin. Colorectal Cancer 2017, 16, 124-128. [CrossRef]

216. Shigematsu, Y.; Inamura, K.; Mise, Y.; Saiura, A.; Rehnberg, E.; Yamammoto, N.; Ishikawa, Y.; Takahashi, S.; Kanda, H. CDX2 expression is concordant between primary colorectal cancer lesions and corresponding liver metastases independent of chemotherapy: A single-center retrospective study in Japan. Oncotarget 2018, 9, 17056-17065. [CrossRef] [PubMed]

217. Xu, W.; Zhu, Y.; Shen, W.; Ding, W.; Wu, T.; Guo, Y.; Chen, X.; Zhou, M.; Chen, Y.; Cui, L.; et al. Combination of CDX2 expression and T stage improves prognostic prediction of colorectal cancer. J. Int. Med. Res. 2019, 47, 1829-1842. [CrossRef] 
218. Rajarajan, S.; Anupamam, C.E.; Jose, B.; Correa, M.; Sengupta, S.; Prabhu, J.S. Identification of colorectal cancers with defective DNA damage repair by immunohistochemical profiling of mismatch repair proteins, CDX2 and BRCAMol. Clin. Oncol. 2020, $13,57$.

219. Nishiuchi, A.; Hisamori, S.; Sakaguchi, M.; Fukuyama, K.; Hoshino, N.; Itatani, Y.; Honma, S.; Maekawa, H.; Nishigori, T.; Tsunodal, S.; et al. MicroRNA-9-5p-CDX2 axis: A useful prognostic biomarker for patients with stage II/III colorectal cancer. Cancers 2019, 11, 1891. [CrossRef]

220. Dalerba, P.; Sahoo, D.; Paik, S. CDX2 as a prognostic biomarker in stage II and stage III colon cancer. N. Engl. J. Med. 2016, 374, 211-222. [CrossRef]

221. Pilati, C.; Taieb, J.; Balogoun, R.; Marisa, L.; de Reynies, A.; Laurent-Puig, P. CDX2 prognostic value in stage II/III resected colon cancer is related to CMS classification. Ann. Oncol. 2017, 28, 1032-1035. [CrossRef] [PubMed]

222. Olsen, J.; Eiholm, S.; Kirkeby, L.T.; Espersen, M.L.; Jess, P.; Gögenür, I.; Olsen, J.; Troelsen, J.T. CDX2 downregulation is associated with poor differentiation and MMR deficiency in colon cancer. Exp. Mol. Pathol. 2016, 100, 59-66. [CrossRef] [PubMed]

223. Aasebo, K.; Dragomir, A.; Sundstrom, M.; Mezheyeuski, A.; Edqvist, P.H.; Eide, G.E.; Ponten, F.; Pfeiffer, P.; Glimelius, B.; Sorbye, H. CDX2: A prognostic marker in metastatic colorectal cancer defining a better BRAF mutated and a worse KRAS mutated subgroup. Front. Oncol. 2020, 10, 8. [CrossRef]

224. Yin, F.; Xie, H.; Lai, J.; Chen, Y.; Dong, J.; Zhang, X.; Liu, X. Double negativity for expression of YAP1 and CDX2 defines an aggressive type of colitis-associated cancer. Anticancer Res. 2020, 40, 5411-5416. [CrossRef]

225. Dobreva, G.; Chahrour, M.; Dautzenberg, M.; Chirivella, L.; Kanzler, B.; Farinas, I.; Karsenty, G.; Grosschedl, R. SATB2 is a multifunctional determinant of craniofacial patterning and osteoblast differentiation. Cell 2006, 125, 971-986. [CrossRef]

226. FitzPatrick, D.R.; Carr, I.M.; McLaren, L.; Leek, J.P.; Wightman, P.; Williamson, K.; Gautier, P.; McGill, N.; Hayward, C.; Firth, H.; et al. Identification of SATB2 as the cleft palate gene on 2q32-qHum. Mol. Genet. 2003, 12, 2491-2501.

227. Magnusson, K.; de Wit, M.; Brennan, D.J.; Johnson, L.B.; McGee, S.F.; Lundberg, E.; Naicker, K.; Klinger, R.; Kampf, C.; Asplund, A.; et al. SATB2 in combination with cytokeratin 20 identifies over 95\% of all colorectal carcinomas. Am. J. Surg. Pathol. 2011, 35, 937-948. [CrossRef] [PubMed]

228. Zarate, Y.A.; Perry, H.; Ben-Omran, T.; Sellars, E.A.; Stein, Q.; Amureikhi, M.; Simmons, K.; Klein, O.; Fish, J.; Feingold, M.; et al. Further supporting evidence for the SATB2-associated syndrome found through whole exome sequencing. Am. J. Med. Genet. 2015, 167A, 1026-1032. [CrossRef]

229. Berg, K.B.; Schaeffer, D.F. SATB2 as an immunohistochemical marker for colorectal adenocarcinoma: A concise review of benefits and pitfalls. Arch. Pathol. Lab. Med. 2017, 141, 1428-1433. [CrossRef]

230. Brandler, T.C.; Jelloul, F.Z.; Soto, D.; Das, K.; Rosen, L.; Bhuiya, T.A. Young investigator challenge: Cadherin-17 and SATB2 in cytology specimens: Do these new immunostains help in differentiating metastatic colorectal adenocarcinoma from adenocarcinomas of other origins? Cancer Cytopathol. 2015, 123, 706-713. [CrossRef]

231. Neri, G.; Arpa, G.; Guerini, C.; Grillo, F.; Lenti, M.V.; Giuffrida, P.; Furlan, D.; Sessa, F.; Quaquarini, E.; Viglio, A.; et al. Small bowel adenocarcinomas featuring special AT-rich sequence-binding protein 2 (SATB2) expression and a colorectal cancer-like immunophenotype: A potential diagnostic pitfall. Cancers 2020, 12, 3441. [CrossRef] [PubMed]

232. Johnstone, C.N.; White, S.J.; Tebbutt, N.C.; Clay, F.J.; Ernst, M.; Biggs, W.H.; Viars, C.S.; Czekay, S.; Arden, K.C.; Heath, J.K. Analysis of the regulation of the A33 antigen gene reveals intestine-specific mechanisms of gene expression. J. Biol. Chem. 2002, 277, 34531-34539. [CrossRef] [PubMed]

233. Fey, D.; Coelho, V.; Petrausch, U.; Schaefer, M.; Keilholz, U.; Thiel, E.; Deckert, P.M. Surface expression of gpA33 is dependent on culture density and cell-cycle phase and is regulated by intracellular traffic rather than gene transcription. Cancer Biother. Radiopharm. 2008, 23, 65-73.

234. Ackerman, M.E.; Chalouni, C.; Schmidt, M.M.; Raman, V.V.; Ritter, G.; Old, L.J.; Mellman, I.; Wittrup, K.D. A33 antigen displays persistent surface expression. Cancer Immunol. Immunother. 2008, 57, 1017-1027. [CrossRef]

235. Kuespert, K.; Pils, S.; Hauck, C.R. CEACAMs: Their role in physiology and pathophysiology. Curr. Opin. Cell Biol. 2006, 18, 565-571. [CrossRef] [PubMed]

236. Chretien, I.; Marcuz, A.; Courtet, M.; Katevuo, K.; Vainio, O.; Heath, J.K.; White, S.J.; Du Pasquier, L. CTX, a Xenopus thymocyte receptor, defines a molecular family conserved throughout vertebrates. Eur. J. Immunol. 1998, 28, 4094-4104. [CrossRef]

237. Bazzoni, G. The JAM family of junctional adhesion molecules. Curr. Opin. Cell Biol. 2003, 15, 525-530. [CrossRef]

238. Wong, N.A.; Adamczyk, L.A.; Evans, S.; Cullen, J.; Oniscu, A.; Oien, K.A. A33 shows similar sensitivity to but is more specific than CDX2 as an immunomarker of colorectal carcinoma. Histopathology 2017, 71, 34-41. [CrossRef]

239. Berndorff, D.; Gessner, R.; Kreft, B.; Schnoy, N.; Lajous-Petter, A.M.; Loch, N.; Reutter, W.; Hortsch, M.; Tauber, R. Liver-intestine cadherin: Molecular cloning and characterization of a novel $\mathrm{Ca}(2+)$-dependent cell adhesion molecule expressed in liver and intestine. J. Cell Biol. 1994, 125, 1353-1369. [CrossRef]

240. Wendeler, M.W.; Drenckhahn, D.; Gessner, R.; Baumgartner, W. Intestinal LI-cadherin acts as a $\mathrm{Ca}^{2+}$-dependent adhesion switch. J. Mol. Biol. 2007, 370, 220-230. [CrossRef]

241. Su, M.C.; Yuan, R.H.; Lin, C.Y.; Jeng, Y.M. Cadherin-17 is a useful diagnostic marker for adenocarcinomas of the digestive system. Mod. Pathol. 2008, 21, 1379-1386. [CrossRef]

242. Hinoi, T.; Luca, P.C.; Kuick, R.; Hanash, S.; Cho, K.R.; Fearon, E.R. CDX2 regulates liver intestine-cadherin expression in normal and malignant colon epithelium and intestinal metaplasia. Gastroenterology 2002, 123, 1565-1577. [CrossRef] 
243. Panarelli, N.C.; Yantiss, R.K.; Yeh, M.M.; Liu, Y.; Chen, Y.T. Tissue-specific cadherin CDH17 is a useful marker of gastrointestinal adenocarcinomas with higher sensitivity than CDX2. Am. J. Clin. Pathol. 2012, 138, 211-222. [CrossRef]

244. Gessner, R.; Tauber, R. Intestinal cell adhesion molecules: Liver-intestine cadherin. Ann. N. Y. Acad. Sci. 2000, 915, 136-143. [CrossRef] [PubMed]

245. Bartolome, R.A.; Barderas, R.; Torres, S.; Fernandez-Acenero, M.J.; Mendes, M.; Garcia-Foncillas, J.; Lopez-Lucendo, M.; Casal, J.I. Cadherin-17 interacts with $\alpha 2 \beta 1$ integrin to regulate cell proliferation and adhesion in colorectal cancer cells causing liver metastasis. Oncogene 2014, 33, 1658-1669. [CrossRef]

246. Yamada, K.M.; Kennedy, D.W. Dualistic nature of adhesive protein function: Fibronectin and its biologically active peptide fragments can autoinhibit fibronectin function. J. Cell Biol. 1984, 99, 29-36. [CrossRef] [PubMed]

247. Pierschbacher, M.D.; Ruoslahti, E. Cell attachment activity of fibronectin can be duplicated by small synthetic fragments of the molecule. Nature 1984, 309, 30-33. [CrossRef]

248. Bartolome, R.A.; Pelaez-Garcia, A.; Gomez, I.; Torres, S.; Fernandez-Acenero, M.J.; Escudero-Paniagua, B.; Imbaud, I.; Casal, I. An RGD motif present in cadherin 17 induces integrin activation and tumor growth. J. Biol. Chem. 2014, 289, 34801-34814. [CrossRef] [PubMed]

249. Ordonez, N.G. Cadherin 17 is a novel diagnostic marker for adenocarcinomas of the digestive system. Adv. Anat. Pathol. 2014, 21, 131-137. [CrossRef]

250. Abouelkhair, M.B.; Mabrouk, S.H.; Zaki, S.S.A.; Nada, O.H.; Hakim, S.A. The diagnostic value of cadherin 17 and CDX2 expression as immunohistochemical markers in colorectal adenocarcinoma. J. Gastrointest. Cancer 2021, 52, 960-969. [CrossRef]

251. Bian, T.; Zhao, J.; Feng, J.; Zhang, Q.; Qian, L.; Liu, J.; Jiang, D.; Liu, Y.; Zhang, J. Combination of cadherin-17 and SATB homeobox 2 serves as potential optimal makers for the differential diagnosis of pulmonary enteric adenocarcinoma and metastatic colorectal adenocarcinoma. Oncotarget 2017, 8, 63442-63452. [CrossRef]

252. Herrmann, H.; Strelkov, S.V.; Burkhard, P.; Aebi, U. Intermediate filaments: Primary determinants of cell architecture and plasticity. J. Clin. Investig. 2009, 119, 1772-1783. [CrossRef] [PubMed]

253. Karantza, V. Keratins in health and cancer: More than mere epithelial cell markers. Oncogene 2011, 30, 127-138. [CrossRef] [PubMed]

254. Herrmann, H.; Bar, H.; Kreplak, L.; Strelkov, S.V.; Aebi, U. Intermediate filaments: From cell architecture to nanomechanics. Nat. Rev. Mol. Cell Biol. 2007, 8, 562-573. [CrossRef]

255. Kim, S.; Wong, P.; Coulombe, P.A. A keratin cytoskeletal protein regulates protein synthesis and epithelial cell growth. Nature 2006, 441, 362-365. [CrossRef]

256. Oriolo, A.S.; Wald, F.A.; Ramsauer, V.P.; Salas, P.J. Intermediate filaments: A role in epithelial polarity. Exp. Cell Res. 2007, 313, 2255-2264. [CrossRef]

257. Styers, M.L.; Kowalczyk, A.P.; Faundez, V. Intermediate filaments and vesicular membrane traffic: The odd couple's first dance? Traffic 2005, 6, 359-365. [CrossRef]

258. Toivola, D.M.; Tao, G.Z.; Habtezion, A.; Liao, J.; Omary, M.B. Cellular integrity plus: Organelle-related and protein-targeting functions of intermediate filaments. Trends Cell Biol. 2005, 15, 608-617. [CrossRef] [PubMed]

259. Vijayaraj, P.; Kroger, C.; Reuter, U.; Windoffer, R.; Leube, R.E.; Magin, T.M. Keratins regulate protein biosynthesis through localization of GLUT1 and -3 upstream of AMP kinase and Raptor. J. Cell Biol. 2009, 187, 175-184. [CrossRef]

260. Schweizer, J.; Bowden, P.E.; Coulombe, P.A.; Langbein, L.; Lane, E.B.; Magin, T.M.; Maltais, L.; Omary, M.B.; Parry, D.A.D.; Rogers, M.A.; et al. New consensus nomenclature for mammalian keratins. J. Cell. Biol. 2006, 174, 169-174. [CrossRef]

261. Harbaum, L.; Pollheimer, M.J.; Kornprat, P.; Lindtner, R.A.; Schlemmer, A.; Rehak, P.; Langner, C. Keratin 7 expression in colorectal cancer-freak of nature or significant finding? Histopathology 2011, 59, 225-234. [CrossRef]

262. Czapiewski, P.; Bobowicz, M.; Pęksa, R.; Skrzypski, M.; Gorczyński, A.; Szczepańska-Michalska, K.; Korwat, A.; Jankowski, M.; Zegarski, W.; Szulgo-Paczkowska, A.; et al. Keratin 7 expression in lymph node metastases but not in the primary tumour correlates with distant metastases and poor prognosis in colon carcinoma. Pol. J. Pathol. 2016, 67, 228-234. [CrossRef] [PubMed]

263. Jass, J.R. Classification of colorectal cancer based on correlation of clinical, morphological and molecular features. Histopathology 2007, 50, 113-130. [CrossRef] [PubMed]

264. Gurzu, S.; Jung, I. Aberrant pattern of the cytokeratin 7/cytokeratin 20 immunophenotype in colorectal adenocarcinomas with BRAF mutations. Pathol. Res. Pract. 2012, 208, 163-166. [CrossRef] [PubMed]

265. Rosenberg, R.; Hoos, A.; Mueller, J.; Baier, P.; Stricker, D.; Werner, M.; Nekarda, H.; Siewert, J.R. Prognostic significance of cytokeratin-20 reverse transcriptase polymerase chain reaction in lymph nodes of node-negative colorectal cancer patients. J. Clin. Oncol. 2002, 20, 1049-1055. [CrossRef] [PubMed]

266. Harbaum, L.; Pollheimer, M.J.; Kornprat, P.; Lindtner, R.A.; Schlemmer, A.; Rehak, P.; Langner, C. Keratin 20—A diagnostic and prognostic marker in colorectal cancer? Histol. Histopathol. 2012, 27, 347-356.

267. McGregor, D.K.; Wu, T.T.; Rashid, A.; Luthra, R.; Hamilton, S.R. Reduced expression of cytokeratin 20 in colorectal carcinomas with high levels of microsatellite instability. Am. J. Surg. Pathol. 2004, 28, 712-718. [CrossRef]

268. Bayrak, R.; Yenidunya, S.; Haltas, H. Cytokeratin 7 and cytokeratin 20 expression in colorectal adenocarcinomas. Pathol. Res. Pract. 2011, 207, 156-160. [CrossRef] [PubMed]

269. Wong, H.H.; Chu, P. Immunohistochemical features of the gastrointestinal tract tumors. J. Gastrointest. Oncol. 2012, 3, $262-284$. 
270. Park, S.Y.; Kim, B.H.; Kim, J.H.; Lee, S.; Kang, G.H. Panels of immunohistochemical markers help determine primary sites of metastatic adenocarcinoma. Arch. Pathol. Lab. Med. 2007, 131, 1561-1567. [CrossRef] [PubMed]

271. Shin, J.H.; Bae, J.H.; Lee, A.; Jung, C.K.; Yim, H.W.; Park, J.S.; Lee, K.Y. CK7, CK20, CDX2 and MUC2 Immunohistochemical staining used to distinguish metastatic colorectal carcinoma involving ovary from primary ovarian mucinous adenocarcinoma. Jpn. J. Clin. Oncol. 2010, 40, 208-213. [CrossRef]

272. Al-Maghrabi, J.; Emam, E.; Gomaa, W. Immunohistochemical staining of cytokeratin 20 and cytokeratin 7 in colorectal carcinomas: Four different immunostaining profiles. Saudi J. Gastroenterol. 2018, 24, 129-134. [CrossRef]

273. Hernandez, B.Y.; Frierson, H.F.; Moskaluk, C.A.; Li, Y.J.; Clegg, L.; Cote, T.R.; McCusker, M.E.; Hankey, B.F.; Edwards, B.K.; Goodman, M.T. CK20 and CK7 protein expression in colorectal cancer: Demonstration of the utility of a population-based tissue microarray. Hum. Pathol. 2005, 36, 275-281. [CrossRef]

274. Park, S.Y.; Kim, H.S.; Hong, E.K.; Kim, W.H. Expression of cytokeratins 7 and 20 in primary carcinomas of the stomach and colorectum and their value in the differential diagnosis of metastatic carcinomas to the ovary. Hum. Pathol. 2002, 33, 1078-1085. [CrossRef]

275. Waseem, A.; Dogan, B.; Tidman, N.; Alam, Y.; Purkis, P.; Jackson, S.; Lalli, A.; Machesney, M.; Leigh, I.M. Keratin 15 expression in stratified epithelia: Downregulation in activated keratinocytes. J. Investig. Dermatol. 1999, 112, 362-369. [CrossRef] [PubMed]

276. Chong, L.Y.; Cheok, P.Y.; Tan, W.J.; Thike, A.A.; Allen, G.; Ang, M.K.; Ooi, A.S.; Tan, P.; Teh, B.T.; Tan, P.H. Keratin 15, transcobalamin I and homeobox gene Hox-B13 expression in breast phyllodes tumors: Novel markers in biological classification. Breast Cancer Res. Treat. 2012, 132, 143-151. [CrossRef] [PubMed]

277. Mahalingam, M.; Srivastava, A.; Hoang, M.P. Expression of stem-cell markers (cytokeratin 15 and nestin) in primary adnexal neoplasms-clues to etiopathogenesis. Am. J. Dermatopathol. 2010, 32, 774-779. [CrossRef]

278. Gelfand, R.; Vernet, D.; Bruhn, K.W.; Sarkissyan, S.; Heber, D.; Vadgama, J.V.; Gonzalez-cadavid, N.F. Long-term exposure of MCF-7 breast cancer cells to ethanol stimulates oncogenic features. Int. J. Oncol. 2017, 50, 49-65. [CrossRef] [PubMed]

279. Hatta, M.; Miyake, Y.; Uchida, K.; Yamazaki, J. Keratin 13 gene is epigenetically suppressed during transforming growth factor-beta1-induced epithelial-mesenchymal transition in a human keratinocyte cell line. Biochem. Biophys. Res. Commun. 2018, 496, 381-386. [CrossRef] [PubMed]

280. Lion, M.; Bisio, A.; Tebaldi, T.; De Sanctis, V.; Menendez, D.; Resnick, M.A.; Ciribilli, Y.; Inga, A. Interaction between p53 and estradiol pathways in transcriptional responses to chemotherapeutics. Cell Cycle 2013, 12, 1211-1224. [CrossRef]

281. Cimino, D.; Fuso, L.; Sfiligoi, C.; Biglia, N.; Ponzone, R.; Maggiorotto, F.; Russo, G.; Cicatiello, L.; Weisz, A.; Taverna, D.; et al. Identification of new genes associated with breast cancer progression by gene expression analysis of predefined sets of neoplastic tissues. Int. J. Cancer 2008, 123, 1327-1338. [CrossRef]

282. Gomez-Morales, M.; Camara-Pulido, M.; Miranda-Leon, M.T.; Sanchez-Palencia, A.; Boyero, L.; Gomez-Capilla, J.A.; FarezVidal, M.E. Differential immunohistochemical localization of desmosomal plaque-related proteins in non-small-cell lung cancer. Histopathology 2013, 63, 103-113. [CrossRef]

283. Khanom, R.; Sakamoto, K.; Pal, S.K.; Shimida, Y.; Morita, K.; Omura, K.; Miki, Y.; Yamaguchi, A. Expression of basal cell keratin 15 and keratin 19 in oral squamous neoplasms represents diverse pathophysiologies. Histol. Histopathol. 2012, 27, 949-959. [PubMed]

284. Rao, X.; Wang, J.; Song, H.M.; Deng, B.; Li, J.G. KRT15 overexpression predicts poor prognosis in colorectal cancer. Neoplasma 2020, 67, 410-414. [CrossRef]

285. Lai, Y.C.; Cheng, C.C.; Lai, Y.S.; Liu, Y.H. Cytokeratin 18-associated histone 3 modulation in hepatocellular carcinoma: A mini review. Cancer Genomics Proteomics 2017, 14, 219-223.

286. Fortier, A.M.; Asselin, E.; Cadrin, M. Keratin 8 and 18 loss in epithelial cancer cells increases collective cell migration and cisplatin sensitivity through claudin1 up-regulation. J. Biol. Chem. 2013, 288, 11555-11571. [CrossRef] [PubMed]

287. Owens, D.W.; Lane, E.B. Keratin mutations and intestinal pathology. J. Pathol. 2004, 204, 377-385. [CrossRef]

288. Zhang, J.; Hu, S.; Li, Y. KRT18 is correlated with the malignant status and acts as an oncogene in colorectal cancer. Biosci. Rep. 2019, 39, BSR20190884. [CrossRef]

289. Bertorelle, R.; Briarava, M.; Rampazzo, E.; Biasini, L.; Agostini, M.; Maretto, I.; Lonardi, S.; Friso, M.L.; Mescoli, C.; Zagonel, V.; et al. Telomerase is an independent prognostic marker of overall survival in patients with colorectal cancer. Br. J. Cancer 2013, 108, 278-284. [CrossRef] [PubMed]

290. Kim, N.W.; Piatyszek, M.A.; Prowse, K.R.; Harley, C.B.; West, M.D.; Ho, M.D.; Coviello, G.M.; Wright, W.E.; Weinrich, S.L.; Shay, J.W. Specific associ-ation of human telomerase activity with immortal cells and cancer. Science 1994, 266, 2011-2015. [CrossRef] [PubMed]

291. Nakamura, T.M.; Morin, G.B.; Chapman, K.B.; Weinrich, S.L.; Andrews, W.H.; Lingner, J.; Harley, C.B.; Cech, T.R. Telomerase catalytic subunit homologs from fission yeast and human. Science 1997, 277, 955-959. [CrossRef]

292. Chen, C.H.; Chen, R.J. Prevalence of telomerase activity in human cancer. J. Formos. Med. Assoc. 2011, 110, 275-289. [CrossRef]

293. Bertorelle, R.; Rampazzo, E.; Pucciarelli, S.; Nitti, D.; De Rossi, A. Telomeres, telomerase and colorectal cancer. World J. Gastroenterol. 2014, 20, 1940-1945. [CrossRef] [PubMed]

294. Terrin, L.; Rampazzo, E.; Pucciarelli, S.; Agostini, M.; Bertorelle, R.; Esposito, G.; Del Bianco, P.; Nitti, D.; De Rossi, A. Relationship between tumor and plasma levels of hTERT mRNA in patients with colorectal cancer: Implications for monitoring of neoplastic disease. Clin. Cancer Res. 2008, 14, 7444-7451. [CrossRef] [PubMed] 
295. Fernadez-Marcelo, T.; Sanchez-Pernaute, A.; Pascua, I.; De Juan, C.; Head, J.; Torres-Garcia, A.J.; Iniesta, P. Clinical relevance of telomere status and telomerase activity in colorectal cancer. PLOS ONE 2016, 11, e0149626.

296. Bae, S.U.; Park, W.J.; Jeong, W.K.; Baek, S.K.; Lee, H.W.; Lee, J.H. Prognostic impact of telomeric repeat-containing RNA expression on long-term oncologic outcomes in colorectal cancer. Medicine 2019, 98, 314932. [CrossRef]

297. Ayiomamitis, G.D.; Notas, G.; Zaravinos, A.; Zizi-Sermpetzoglou, A.; Georgiadou, M.; Sfakianaki, O.; Kouroumallis, E. Differences in telomerase activity between colon and rectal cancer. Can. J. Surg. 2014, 57, 199-208. [CrossRef] [PubMed]

298. Tatsumoto, N.; Hiyama, E.; Murakami, Y.; Imamura, Y.; Shay, J.W.; Matsuura, Y.; Yokoyama, T. High telomerase activity is an independent prognostic indicator of poor outcome in colorectal cancer. Clin. Cancer Res. 2000, 6, 2696-2701.

299. Gertler, R.; Rosenberg, R.; Stricker, D.; Friederichs, J.; Hoos, A.; Werner, M.; Ulm, K.; Holzmann, B.; Nekarda, H.; Siewert, J.R. Telomere length and human telomerase reverse transcriptase expression as markers for progression and prognosis of colorectal carcinoma. J. Clin. Oncol. 2004, 22, 1807-1814. [CrossRef]

300. Rosenberg, R.; Gertler, R.; Stricker, D.; Lassmann, S.; Werner, M.; Nekarda, H.; Siewert, J.R. Telomere length and hTERT expression in patients with colorectal carcinoma. Recent Results Cancer Res. 2003, 162, 177-181.

301. Tahara, H.; Yasui, W.; Tahara, E.; Fujimoto, J.; Ito, K.; Tamai, K.; Nakayama, J.; Ishikawa, F.; Tahara, E.; Ide, T. Immunohistochemical detection of human telomerase catalytic component, hTERT, in human colorectal tumor and non-tumor tissue sections. Oncogene 1999, 18, 1561-1567. [CrossRef] [PubMed]

302. Kammori, M.; Kanauchi, H.; Nakamura, K.; Kawahara, M.; Weber, T.K.; Mafune, K.I.; Kaminishi, M.; Takubo, K. Demonstration of human telomerase reverse transcriptase in human colorectal carcinomas by in situ hybridization. Int. J. Oncol. 2002, $20,15-21$. [CrossRef] [PubMed]

303. Engelhardt, M.; Drullinsky, P.; Guillem, J.; Moore, M.A. Telomerase and telomere length in the development and progression of premalignant lesions to colorectal cancer. Clin. Cancer Res. 1997, 3, 1931-1941. [PubMed]

304. Yoshida, K.; Sugino, T.; Goodison, S.; Warren, B.F.; Nolan, D.; Wadsworth, S.; Mortensen, N.J.; Toge, T.; Tahara, E.; Tarin, D. Detection of telomerase activity in exfoliated cancer cells in colonic luminal washings and its related clinical implications. Br. J. Cancer 1997, 75, 548-553. [CrossRef]

305. Myung, S.J.; Yang, S.K.; Chang, H.S.; Byeon, J.S.; Kim, K.J.; Hong, S.S.; Jeong, J.Y.; Lee, S.M.; Hong, W.S.; Kim, J.H.; et al. Clinical usefulness of telomerase for the detection of colon cancer in ulcerative colitis patients. J. Gastroenterol. Hepatol. 2005, 20, 1578-1583. [CrossRef]

306. Kawanishi-Tabata, R.; Lopez, F.; Fratantonio, S.; Kim, N.; Goldblum, J.; Tubbs, R.; Elson, P.; Lavery, I.; Bukowski, R.M.; Ganapathi, R.; et al. Telomerase activity in stage II colorectal carcinoma. Cancer 2002, 95, 1834-1839. [CrossRef]

307. Fang, D.C.; Young, J.; Luo, Y.H.; Lu, R.; Jass, J. Detection of telomerase activity in biopsy samples of colorectal cancer. J. Gastroenterol. Hepatol. 1999, 14, 328-332. [CrossRef]

308. Ishibashi, K.; Hirose, K.; Kato, H.; Ogawa, K.; Haga, S. Determining the telomerase activity of exfoliated cells in intestinal lavage solution to detect colorectal carcinoma. Anticancer Res. 1999, 19, 2831-2836.

309. Nikolouzakis, T.K.; Vassilopoulou, L.; Fragkiadaki, P.; Sapsakos, T.M.; Papadakis, G.Z.; Spandidos, D.A.; Tsatsakis, A.M.; Tsiaoussis, J. Improving diagnosis, prognosis and prediction by using biomarkers in CRC patients. (Review). Oncol. Rep. 2018, 39, 2455-2472. [CrossRef]

310. Ahlquist, D.A.; McGill, D.B.; Schwartz, S.; Taylor, W.F.; Owen, R.A. Fecal blood levels in health and disease. A study using HemoQuant. N. Engl. J. Med. 1985, 312, 1422-1428. [CrossRef]

311. Vu, H.V.; Burke, C.A. Advances in colorectal cancer screening. Curr. Gastroenterol. Rep. 2009, 11, 406-412. [CrossRef] [PubMed]

312. Burch, J.; Soares-Weiser, K.; St John, D.; Duffy, S.; Smith, S.; Keijnen, J.; Westwood, M. Diagnostic accuracy of faecal occult blood tests used in screening for colorectal cancer: A systematic review. J. Med. Screen. 2007, 14, 132-137. [CrossRef] [PubMed]

313. Rengucci, C.; De Maio, G.; Menghi, M.; Benzi, F.; Calistri, D. Evaluation of colorectal cancer risk and prevalence by stool DNA integrity detection. J. Vis. Exp. 2020, 160. [CrossRef] [PubMed]

314. Hirai, H.W.; Tsoi, K.K.F.; Chan, J.Y.C.; Wong, S.H.; Ching, J.Y.L.; Wong, M.C.S.; Wu, J.C.Y.; Chan, F.K.L.; Sung, J.J.Y.; Ng, S.C. Systematic review with meta-analysis: Faecal occult blood tests show lower colorectal cancer detection rates in the proximal colon in colonoscopy-verified diagnostic studies. Aliment. Pharmacol. Ther. 2016, 43, 755-764. [CrossRef] [PubMed]

315. Dollinger, M.M.; Behl, S.; Fleig, W.E. Early detection of colorectal cancer: A multi-center preclinical case cohort study for validation of a combined DNA stool test. Clin. Lab. 2018, 64, 1719-1730. [CrossRef]

316. Okada, T.; Tanaka, K.; Kawachi, H.; Ito, T.; Nishikage, T.; Odagaki, T.; Zarate, A.J.; Kronberg, U.; Lopez-Kostner, F.; Karelovic, S.; et al. International collaboration between Japan and Chile to improve detection rates in colorectal cancer screening. Cancer 2016, 122, 71-77. [CrossRef]

317. Rank, K.M.; Shaukat, A. Stool based testing for colorectal cancer: An overview of available evidence. Curr. Gastroenterol. Rep. 2017, 19, 39. [CrossRef]

318. Kościelniak-Merak, B.; Radosavljević, B.; Zając, A.; Tomasik, P.J. Faecal occult blood point-of-care tests. J. Gastrointest. Cancer 2018, 49, 402-405. [CrossRef]

319. Robertson, D.J.; Imperiale, T.F. Stool testing for colorectal cancer screening. Gastroenterology 2015, 149, 1286-1293. [CrossRef]

320. Dickinson, B.T.; Kisiel, J.; Ahlquist, D.A.; Grady, W.M. Molecular markers for colorectal cancer screening. Gut 2015, 64, 1485-1494. [CrossRef] 
321. Janz, T.; Lu, K.; Povlow, M.R.; Urso, B. A Review of colorectal cancer detection modalities, stool DNA, and fecal immunochemistry testing in adults over the age of 50. Cureus 2016, 8, e931. [CrossRef]

322. Issa, I.A.; Noureddine, M. Colorectal cancer screening: An updated review of the available options. World J. Gastroenterol. 2017, 23, 5086-5096. [CrossRef]

323. Hundt, S.; Haug, U.; Brenner, H. Comparative evaluation of immunochemical fecal occult blood tests for colorectal adenoma detection. Ann. Intern. Med. 2009, 150, 162-169. [CrossRef] [PubMed]

324. Van Doorn, S.C.; Stegeman, I.; Stroobants, A.K.; Mundt, M.W.; de Wijkerslooth, T.R.; Fockens, P.; Kuipers, E.J.; Bossuyt, P.M.; Dekker, E. Fecal immunochemical testing results and characteristics of colonic lesions. Endoscopy 2015, 47, 1011-1017. [CrossRef]

325. Lee, J.K.; Liles, E.G.; Bent, S.; Levin, T.R.; Corley, D.A. Accuracy of fecal immunochemical tests for colorectal cancer: Systematic review and meta-analysis. Ann. Intern. Med. 2014, 160, 171. [CrossRef]

326. Lieberman, D.A.; Weiss, D.G. One-time screening for colorectal cancer with combined fecal occult-blood testing and examination of the distal colon. N. Engl. J. Med. 2001, 345, 555-560. [CrossRef]

327. Niedermaier, T.; Balavarca, Y.; Brenner, H. Stage-specific sensitivity of fecal immunochemical tests for detecting colorectal cancer: Systematic review and meta-analysis. Am. J. Gastroenterol. 2020, 115, 56-69. [CrossRef] [PubMed]

328. Clarke, N.; Sharp, L.; Osborne, A.; Kearney, P.M. Comparison of uptake of colorectal cancer screening based on fecal immunochemical testing (FIT) in males and females: A systematic review and meta-analysis. Cancer Epidemiol. Biomark. Prev. 2015, 24, 39-347. [CrossRef]

329. Okada, T.; Odagaki, T.; Lopez-Kostner, F.; Zarate, A.J.; Ponce, A.; Kronberg, U.; Karelovic, S.; Flores, S.; Estela, R.; Ito, T.; et al. Colorectal cancer risk factors in asymptomatic Chilean population: A survey of international collaboration between Japan and Chile. Eur. J. Cancer Prev. 2020, 29, 127-133. [CrossRef] [PubMed]

330. Bailey, J.R.; Aggarwal, A.; Imperiale, T.F. Colorectal cancer screening: Stool DNA and other noninvasive modalities. Gut Liver 2016, 10, 204-211. [CrossRef]

331. Carethers, J.M. Fecal DNA testing for colorectal cancer screening. Annu. Rev. Med. 2020, 71, 59-69. [CrossRef] [PubMed]

332. Iannone, A.; Losurdo, G.; Pricci, M.; Girardi, B.; Massaro, A.; Principi, M.; Barone, M.; Ierardi, E.; Di Leo, A. Stool investigations for colorectal cancer screening: From occult blood Test to DNA analysis. J. Gastrointest. Cancer 2016, 47, 143-151. [CrossRef]

333. Eckmann, J.D.; Ebner, D.W.; Kisiel, J.B. Multi-target stool DNA testing for colorectal cancer screening: Emerging learning on real-world performance. Curr. Treat. Options Gastroenterol. 2020, 18, 109-119. [CrossRef]

334. Imperiale, T.F.; Ransohoff, D.F.; Itzkowitz, S.H.; Levin, T.R.; Lavin, P.; Lidgard, G.P.; Ahlquist, D.A.; Berger, B.M. Multitarget stool DNA testing for colorectal-cancer screening. N. Engl. J. Med. 2014, 370, 1287-1297. [CrossRef]

335. Malik, P. A novel multitarget stool DNA test for colorectal cancer screening. Postgrad. Med. 2016, 128, 268-272. [CrossRef] [PubMed]

336. Wang, J.; Liu, S.; Wang, H.; Zheng, L.; Zhou, C.; Li, G.; Huang, R.; Wang, H.; Li, C.; Fan, X.; et al. Robust performance of a novel stool DNA test of methylated SDC2 for colorectal cancer detection: A multicenter clinical study. Clin. Epigenetics 2020, $12,162$. [CrossRef] [PubMed]

337. Bosch, L.J.; Melotte, V.; Mongera, S.; Daenen, K.L.; Coupe, V.M.H.; van Turenhout, S.T.; Stoop, E.M.; de Wijkerslooth, T.R.; Mulder, C.J.J.; Rausch, C.; et al. Multitarget stool DNA test performance in an average-risk colorectal cancer screening population. Am. J. Gastroeneterol. 2019, 114, 1909-1918. [CrossRef]

338. Eckmann, J.D.; Ebner, D.W.; Bering, J.; Kahn, A.; Rodriguez, E.; Devens, M.E.; Lowrie, K.L.; Doering, K.; Then, S.; Burger, K.N.; et al. Multitarget stool DNA screening in clinical practice: High positive predictive value for colorectal neoplasia regardless of exposure to previous colonoscopy. Am. J. Gastroenterol. 2020, 15, 608-615. [CrossRef]

339. Price, M.; Lester, L.; Chiniwala, R.; Berger, B. Multitarget stool DNA tests increases colorectal cancer screening among previously noncompliant Medicare patients. World J. Gastroenterol. 2017, 23, 464-471. [CrossRef]

340. Kisiel, J.B.; Eckmann, J.D.; Limburg, P.J. Multitarget stool DNA for average risk colorectal cancer screening: Major achievements and future directions. J. Gastrointest. Endosc. Clin. N. Am. 2020, 30, 553-568. [CrossRef]

341. Yuan, Y.; Qu, B.; Yan, J.; Wang, H.; Yin, L.; Han, Q. Diagnostic value of aberrant gene methylation in stool samples for colorectal cancer or adenomas: A meta-analysis. Panminerva Med. 2015, 57, 55-64.

342. Pickhardt, P.J.; Graffy, P.M.; Weigman, B.; Deiss-Yehiely, N.; Hassan, C.; Weiss, J.M. Diagnostic performance of multitarget stool DNA and CT colonography for noninvasive colorectal cancer screening. Radiology 2020, 297, 120-129. [CrossRef]

343. Qian, L.Y.; Zhang, W. The diagnostic value of DNA hypermethylation in stool for colorectal cancer: A meta-analysis. J. Cancer Res. Ther. 2014, 10, 287-291. [CrossRef]

344. Zhai, R.L.; Xu, F.; Zhang, P.; Zhang, W.L.; Wang, H.; Wang, J.L.; Cai, K.L.; Long, Y.P.; Lu, X.M.; Tao, K.T.; et al. The diagnostic performance of stool DNA testing for colorectal cancer: A systematic review and meta-analysis. Medicine 2016, 95, e2129. [CrossRef]

345. Zhang, H.; Qi, J.; Wu, Y.Q.; Zhang, P.; Jiang, J.; Wang, Q.X.; Zhu, Y.Q. Accuracy of early detection of colorectal tumours by stool methylation markers: A meta-analysis. World J. Gastroenterol. 2014, 20, 14040-14050. [CrossRef]

346. Luo, Y.X.; Chen, D.K.; Song, S.X.; Wang, L.; Wang, J.P. Aberrant methylation of genes in stool samples as diagnostic biomarkers for colorectal cancer or adenomas: A meta-analysis. Int. J. Clin. Pract. 2011, 65, 1313-1320. [CrossRef]

347. Mojtabanezhad Shariatpanahi, A.; Yassi, M.; Nouraie, M.; Sahebkar, A.; Tabrizi, F.V.; Kerachian, M.A. The importance of stool DNA methylation in colorectal cancer diagnosis: A meta-analysis. PLoS ONE 2018, 13, e0200735. [CrossRef] 
348. Gachabayov, M.; Lebovics, E.; Rojas, A.; Felsenreich, D.M.; Latifi, R.; Bergamaschi, R. Performance evaluation of stool DNA methylation test in colorectal cancers screening: A systemic review and metaanalysis. Color. Dis. 2021, 23, 1030-1042. [CrossRef] [PubMed]

349. Muller, H.M.; Oberwalder, M.; Fiegl, H.; Morandell, M.; Goebel, G.; Zitt, M.; Muhlthaler, M.; Ofner, D.; Margreiter, R.; Widchwendter, M. Methylation changes in faecal DNA: A marker for colorectal cancer screening? Lancet 2004, 363, $1283-1285$. [CrossRef]

350. Petko, Z.; Ghiassi, M.; Shuber, A.; Gorham, J.; Smalley, W.; Washington, M.K.; Schultenover, S.; Gautam, S.; Markowitz, S.D.; Grady, W.M. Aberrantly methylated CDKN2A, MGMT, and MLH1 in colon polyps and in fecal DNA from patients with colorectal polyps. Clin. Cancer Res. 2005, 11, 1203-1209. [PubMed]

351. Huang, Z.; Li, L.; Wang, J. Hypermethylation of SFRP2 as a potential marker for stool-based detection of colorectal cancer and precancerous lesions. Dig. Dis. Sci. 2007, 52, 2287-2291. [CrossRef]

352. Itzkowitz, S.H.; Jandorf, L.; Brand, R.; Rabeneck, L.; Schroy, P.C., III; Sontang, S.; Johnson, D.; Skoletsky, J.; Durkee, K.; Markowitz, S.; et al. Improved fecal DNA test for colorectal cancer screening. Clin. Gastroenterol. Hepatol. 2007, 5, 111-117. [CrossRef]

353. Wang, D.R.; Tang, D. Hypermethylated SFRP2 gene in fecal DNA is a high potential biomarker for colorectal cancer nininvasive screening. World J. Gastroenterol. 2008, 14, 524-531. [CrossRef]

354. Itzkowitz, S.; Brand, R.; Jandorf, L.; Durkee, K.; Millholland, J.; Rabeneck, L.; Schroy, P.C., 3rd; Sontag, S.; Johnson, D.; Markowitz, S.; et al. A simplified, noninvasive stool DNA test for colorectal cancer detection. Am. J. Gastroenterol. 2008, 103, 2862-2870. [CrossRef]

355. Oberwalder, M.; Zitt, M.; Wontner, C.; Fiegl, H.; Goebel, G.; Zitt, M.; Kohle, O.; Muhlmann, G.; Ofner, D.; Margreiter, R.; et al. SFRP2 methylation in fecal DNA-a marker for colorectal polyps. Int. J. Color. Dis. 2008, 23, 15-19. [CrossRef] [PubMed]

356. Glockner, S.C.; Dhir, M.; Yi, J.M.; McGarvey, K.E.; Van Neste, L.; Louwagie, J.; Chan, T.A.; Kleeberger, W.; de Bruine, A.P.; Smits, K.M.; et al. Methylation of TFPI2 in stool DNA: A potential novel biomarker for the detection of colorectal cancer. Cancer Res. 2009, 69, 4691-4699. [CrossRef] [PubMed]

357. Melotte, V.; Lentjes, M.H.; van den Bosch, S.M.; Hellebrekers, D.M.; de Hoon, J.P.; Wouters, K.A.; Daenen, K.L.; Partouns-Hendriks, I.E.; Stessels, F.; Louwagie, J.; et al. N-Myc downstream-regulated gene 4 (NDRG4): A candidate tumor suppressor gene and potential biomarker for colorectal cancer. J. Natl. Cancer Inst. 2009, 101, 916-927. [CrossRef] [PubMed]

358. Hellebrekers, D.M.E.I.; Lentjes, M.H.F.M.; van den Bosch, S.; Melotte, V.; Wouters, K.A.D.; Daenen, K.L.J.; Smits, K.M.; Kiyama, Y.; Yuasa, Y.; Sanduleanu, S.; et al. GATA4 and GATA5 are potential tumor suppressors and biomarkers in colorectal cancer. Clin. Cancer Res. 2009, 15, 3900-3907. [CrossRef]

359. Ausch, C.; Kim, Y.H.; Tsuchiya, K.D.; Dzieciatkowski, S.; Washington, M.K.; Paraskeva, C.; Radich, J.; Grady, W.M. Comparative analysis of PCR-based biomarker assay methods for colorectal polyp detection from fecal DNA. Clin. Chem. 2009, 55, 1559-1563. [CrossRef] [PubMed]

360. Nagasaka, T.; Tanaka, N.; Cullinds, H.M.; Sun, D.S.; Sasamoto, H.; Uchida, T.; Koi, M.; Nishida, N.; Naomoto, Y.; Boland, C.R.; et al. Analysis of fecal DNA methylation to detect gastrointestinal neoplasia. J. Natl. Cancer Inst. 2009, 101, 1244-1258. [CrossRef]

361. Chang, E.; Park, D.I.; Kim, Y.J.; Kim, B.K.; Park, J.H.; Kim, H.J.; Cho, Y.K.; Sohn, C.I.; Jeon, W.K.; Kim, B.I.; et al. Detection of colorectal neoplasm using promoter methylation of ITGA4, SFRP2, and p16 in stool samples: A preliminary report in Korean patients. Hepatogastroenterology 2010, 57, 720-727. [PubMed]

362. Zhang, J.P.; Wang, J.; Gui, Y.L.; Zhu, Q.Q.; Xu, Z.W.; Li, J.S. Human stool vimentin, oncostatin M receptor and tissue factor pathway inhibitor 2 gene methylation analysis for the detection of colorectal neoplasms. Zhonghua Yi Xue Za Zhi 2011, 91, 2482-2484. (In Chinese) [PubMed]

363. Bosch, L.J.W.; Oort, F.A.; Neerincx, M.; Khalid-de Bakker, C.A.J.; Terhaar sive Droste, J.S.; Melotte, V.; Jonkers, D.M.; Masclee, A.; Mongera, S.; Grooteclaes, M.; et al. DNA methylation of phosphatase and actin regulator 3 detects colorectal cancer in stool and complements FIT. Cancer Prev. Res. 2012, 5, 464-472. [CrossRef]

364. Kisiel, J.B.; Yab, T.C.; Nazer Hussain, F.T.; Taylor, W.R.; Garrity-Park, M.M.; Sandborn, W.J.; Loftus, E.V.; Wolff, B.G.; Smyrk, T.C.; Itzkowitz, S.H.; et al. Stool DNA testing for the detection of colorectal neoplasia in patients with inflammatory bowel disease. Aliment. Pharmacol. Ther. 2013, 37, 546-554. [CrossRef] [PubMed]

365. Amiot, A.; Mansour, H.; Baumgaertner, I.; Delchier, J.C.; Tournigand, C.; Furet, J.P.; Carrau, J.P.; Canoui-Poitrine, F.; Sobhani, I CRC of Val De Marne. The detection of the methylated Wif-1 gene is more accurate than a fecal occult blood test for colorectal cancer screening. PLOS ONE 2014, 9, e99233.

366. Zhang, H.; Zhu, Y.Q.; Wu, Y.Q.; Zhang, P.; Qi, J. Detection of promoter hypermethylation of Wnt antagonist genes in fecal samples for diagnosis of early colorectal cancer. World J. Gastroenterol. 2014, 20, 6329-6335. [CrossRef]

367. Wu, X.; Song, Y.C.; Cao, P.L.; Zhang, H.; Guo, Q.; Yan, R.; Diao, D.M.; Cheng, Y.; Dang, C.X. Detection of miR-34a and miR-34b/c in stool sample as potential screening biomarkers for noninvasive diagnosis of colorectal cancer. Med. Oncol. 2014, 31,894 . [CrossRef]

368. Xiao, Z.; Li, B.; Wang, G.; Zhu, W.; Wang, Z.; Lin, J.; Xu, A.; Wang, X. Validation of methylation-sensitive high-resolution melting (MS-HRM) for the detection of stool DNA methylation in colorectal neoplasms. Clin. Chim. Acta 2014, 431, 154-163. [CrossRef]

369. Teixeira, Y.; Lima, J.M.; Souza, M.L.; Aguiar, P.; Silva, T.D.; Forones, N.M. Human DNA quantification in the stools of patients with colorectal cancer. Arq. Gastroenterol. 2015, 52, 293-298. [CrossRef] 
370. Li, W.; Zhang, H.; Guo, Q.; Wu, X.; Xu, Z.; Dang, C.; Xia, P.; Song, Y. Detection of SNCA and FBN1 methylation in the stool as a biomarker for colorectal cancer. Dis. Markers 2015, 2015, 657570. [CrossRef]

371. Park, S.K.; Baek, H.L.; Yu, J.; Kim, J.Y.; Yang, H.J.; Jung, Y.S.; Choi, K.Y.; Kim, H.; Kim, H.O.; Jeong, K.U.; et al. Is methylation analysis of SFRP2, TFPI2, NDRG4, and BMP3 promoters suitable for colorectal cancer screening in the Korean population? Intest. Res. 2017, 15, 495-501. [CrossRef]

372. Sun, M.; Liu, J.; Hu, H.; Guo, P.; Shan, Z.; Yang, H.; Wang, J.; Xiao, W.; Zhou, X. A novel panel of stool-based DNA biomarkers for early screening of colorectal neoplasms in a Chinese population. J. Cancer Res. Clin. Oncol. 2019, 145, 2423-2432. [CrossRef]

373. Liu, R.; Su, X.; Ling, Y.; Zhou, D.; Zhang, X.; Ye, Z.; Ma, J.; Tang, T.; Wang, F.; He, C. A systematic review and quantitative assessment of methylation biomarkers in fecal DNA and colorectal cancer and its precursor, colorectal adenoma. Mutat. Res. 2019, 779, 45-57. [CrossRef]

374. Chen, J.; Sun, H.; Tang, W.; Zhou, L.; Zhan, X.X.; Chen, M.; Wang, S.; Yang, T.; Dai, Y.; Wang, Y.; et al. DNA methylation biomarkers in stool for early screening of colorectal cancer. J. Cancer 2019, 10, 5264-5271. [CrossRef] [PubMed]

375. Liu, X.; Wen, J.; Li, C.; Wang, H.; Wang, J.; Zou, H. High-yield methylation markers for stool-based detection of colorectal cancer. Dig. Dis. Sci. 2020, 65, 1710-1719. [CrossRef] [PubMed]

376. Jin, S.; Ye, Q.; Hong, Y.; Dai, W.; Zhang, C.; Liu, W.; Guo, Y.; Zhu, D.; Zhang, Z.; Chen, S.; et al. A systematic evaluation of stool DNA preparation protocols for colorectal cancer screening via analysis of DNA methylation biomarkers. Clin. Chem. Lab. Med. 2020, 59, 91-99. [CrossRef] [PubMed]

377. Zhao, G.; Liu, X.; Liu, Y.; Li, H.; Ma, Y.; Li, S.; Zhu, Y.; Miao, J.; Xiong, S.; Fei, S.; et al. Aberrant DNA methylation of SEPT9 and SDC2 in stool specimens as an integrated biomarker for colorectal cancer early detection. Front. Genet. 2020, 11, 643. [CrossRef]

378. Niedermaier, T.; Weigl, K.; Hoffmeister, M.; Brenner, H. Fecal immunochemical tests combined with other stool tests for colorectal cancer and advanced adenoma detection: A systematic review. Clin. Transl. Gastroenterol. 2016, 7, e175. [CrossRef]

379. Mu, J.; Huang, Y.; Cai, S.; Li, Q.; Song, Y.; Yuan, Y.; Zhang, S.; Zheng, S. Plausibility of an extensive use of stool DNA test for screening advanced colorectal neoplasia. Clin. Chim. Acta 2020, 501, 42-47. [CrossRef]

380. Levin, T.R.; Corley, D.A.; Jensen, C.D.; Marks, A.R.; Zhao, W.K.; Zebrowski, A.M.; Quinn, V.P.; Browne, L.W.; Taylor, W.R.; Ahlquist, D.A.; et al. Genetic biomarker prevalence is similar in fecal immunochemical test positive and negative colorectal cancer Tissue. Dig. Dis. Sci. 2017, 62, 678-688. [CrossRef]

381. Laugsand, E.A.; Brenne, S.S.; Skorpen, F. DNA methylation markers detected in blood, stool, urine, and tissue in colorectal cancer: A systematic review of paired samples. Int. J. Color. Dis. 2021, 36, 239-252. [CrossRef]

382. Oh, T.; Kim, N.; Moon, Y.; Kim, M.S.; Hoehn, B.D.; Park, C.H.; Kim, T.S.; Kim, N.K.; Chung, H.C.; An, S. Genome-wide identification and validation of a novel methylation biomarker, SDC2, for blood-based detection of colorectal cancer. J. Mol. Diagn. 2013, 15, 498-507. [CrossRef]

383. Mitchell, S.M.; Ross, J.P.; Drew, H.R.; Ho, T.; Brown, G.S.; Saunders, N.F.; Duesing, K.R.; Buckley, M.J.; Dunne, R.; Beetson, I.; et al. A panel of genes methylated with high frequency in colorectal cancer. BMC Cancer 2014, 14, 54. [CrossRef] [PubMed]

384. Niu, F.; Wen, J.; Fu, X.; Li, C.; Zhao, R.; Wu, S.; Yu, H.; Liu, X.; Zhao, X.; Liu, S.; et al. Stool DNA test of methylated Syndecan-2 for the early detection of colorectal neoplasia. Cancer Epidemiol. Biomark. Prev. 2017, 26, 1411-1419. [CrossRef]

385. Han, Y.D.; Oh, T.J.; Chung, T.H.; Jang, H.W.; Kim, Y.N.; An, S.; Kim, N.K. Early detection of colorectal cancer based on presence of methylated syndecan-2 (SDC2) in stool DNA. Clin. Epigenetics 2019, 11, 51. [CrossRef] [PubMed]

386. Su, W.C.; Kao, W.Y.; Chang, T.K.; Tsai, H.L.; Huang, C.W.; Chen, Y.C.; Li, C.C.; Hsieh, Y.C.; Yeh, H.J.; Chang, C.C.; et al. Stool DNA test targeting methylated syndecan-2 (SDC2) as a noninvasive screening method for colorectal cancer. Biosci. Rep. 2021, 41, BSR2021930. [CrossRef]

387. Tang, D.; Liu, J.; Wang, D.R.; Yu, H.F.; Li, Y.K.; Zhang, J.Q. Diagnostic and prognostic value of the methylation status of secreted frizzled-related protein 2 in colorectal cancer. Clin. Investig. Med. 2011, 34, E88-E95. [CrossRef] [PubMed]

388. Sellin, M.E.; Sandblad, L.; Stenmark, S.; Gullberg, M. Deciphering the rules governing assembly order of mammalian septin complexes. Mol. Biol. Cell 2011, 22, 3152-3164. [CrossRef] [PubMed]

389. El Bairi, K.; Tariq, K.; Himri, I.; Jaafari, A.; Smaili, W.; Kandhro, A.H.; Gouri, A.; Ghazi, B. Decoding colorectal cancer epigenomics. Cancer Gene Ther. 2018, 220, 49-76. [CrossRef]

390. Loh, K.; Chia, J.A.; Greco, S.; Cozzi, S.J.; Buttenshaw, R.L.; Bond, C.E.; Simms, L.A.; Pike, T.; Young, J.P.; Jass, J.R.; et al. Bone morphogenic protein 3 inactivation is an early and frequent event in colorectal cancer development. Genes Chromosom. Cancer 2008, 47, 449-460. [CrossRef] [PubMed]

391. Peacock, O.; Lee, A.C.; Larvin, M.; Tufarelli, C.; Lund, J.N. MicroRNAs: Relevant tools for a colorectal surgeon? World J. Surg. 2012, 36, 1881-1892. [CrossRef]

392. Garofalo, M.; Croce, C.M. microRNAs: Master regulators as potential therapeutics in cancer. Annu. Rev. Pharmacol. Toxicol. 2011, 51, 25-43. [CrossRef]

393. Mendell, J.T.; Olson, E.N. MicroRNAs in stress signaling and human disease. Cell 2012, 148, 1172-1187. [CrossRef]

394. Michael, M.Z.; O’Conor, S.M.; van Holst Pellekaan, N.G.; Young, G.P.; James, R.J. Reduced accumulation of specific microRNAs in colorectal neoplasia. Mol. Cancer Res. 2003, 1, 882-891.

395. Volinia, S.; Calin, G.A.; Liu, C.G.; Ambs, S.; Cimmino, A.; Petrocca, F.; Visone, R.; Iorio, M.; Roldo, C.; Ferracin, M.; et al. A microRNA expression signature of human solid tumors defines cancer gene targets. Proc. Natl. Acad. Sci. USA 2006, 103, 2257-2261. [CrossRef] 
396. Okugawa, Y.; Toiyama, Y.; Goel, A. An update on microRNAs as colorectal cancer biomarkers: Where are we and what's next? Expert Rev. Mol. Diagn. 2014, 14, 999-1021. [CrossRef] [PubMed]

397. Koga, Y.; Yasunaga, M.; Takahashi, A.; Kuroda, J.; Moriya, Y.; Akasu, T.; Fujita, S.; Yamamoto, S.; Baba, H.; Matsumura, Y. MicroRNA expression profiling of exfoliated colonocytes isolated from feces for colorectal cancer screening. Cancer Prev. Res. 2010, 3, 1435-1442. [CrossRef]

398. Kalimutho, M.; Del Vecchio Blano, G.; Di Cecilia, S.; Sileri, P.; Cretella, M.; Pallone, F.; Federici, G.; Bernardini, S. Differential expression of miR-144* as a novel fecal-based diagnostic marker for colorectal cancer. J. Gastroenterol. 2011, 46, 1391-1402. [CrossRef] [PubMed]

399. Ahmed, F.E.; Ahmed, N.C.; Vos, P.W.; Bonnerup, C.; Atkins, J.N.; Casey, M.; Nuovo, G.J.; Naziri, W.; Wiley, J.E.; Mota, H.; et al. Diagnostic microRNA markers to screen for sporadic human colon cancer in stool: I. Proof of Principle. Cancer Genom. Proteomics 2013, 10, 93-113.

400. Yau, T.O.; Wu, C.W.; Dong, Y.; Tang, C.M.; Ng, S.S.M.; Chan, F.K.L.; Sung, J.J.Y.; Yu, J. microRNA-221 and microRNA-18a identification in stool as potential biomarkers for the non-invasive diagnosis of colorectal carcinoma. Br. J. Cancer 2014, 111, 1765-1771. [CrossRef] [PubMed]

401. Phua, L.C.; Chue, X.P.; Koh, P.K.; Cheah, P.Y.; Chan, E.C.; Ho, H.K. Global fecal microRNA profiling in the identification of biomarkers for colorectal cancer screening among Asians. Oncol. Rep. 2014, 32, 97-104. [CrossRef]

402. Zhu, Y.; Xu, A.; Li, J.; Fu, J.; Wang, G.; Yang, Y.; Cui, L.; Sun, J. Fecal miR-29a and miR-224 as the noninvasive biomarkers for colorectal cancer. Cancer Biomark. 2016, 16, 259-264. [CrossRef] [PubMed]

403. Yau, T.O.; Wu, C.W.; Tang, C.M.; Chen, Y.; Fang, J.; Dong, Y.; Liang, Q.; Ng, S.S.M.; Chan, F.K.L.; Sung, J.J.Y.; et al. MicroRNA-20a in human faeces as a non-invasive biomarker for colorectal cancer. Oncotarget 2016, 7, 1559-1568. [CrossRef] [PubMed]

404. Wu, C.W.; Cao, X.; Berger, C.K.; Foote, P.H.; Mahoney, D.W.; Simonson, J.A.; Anderson, B.W.; Yab, T.C.; Taylor, W.R.; Boardman, L.A.; et al. Novel approach to fecal Occult Blood Testing by Assay of Erythrocyte-Specific microRNA Markers. Dig. Dis. Sci. 2017, 62, 1985-1994. [CrossRef] [PubMed]

405. Bastaminejad, S.; Taherikalani, M.; Ghanbari, R.; Akbari, A.; Shabab, N.; Saidijam, M. Investigation of microRNA-21 expression levels in serum and stool as a potential non-invasive biomarker for diagnosis of colorectal Cancer. Iran. Biomed. J. 2017, 21, 106-113. [CrossRef]

406. Choi, H.H.; Cho, Y.S.; Choi, H.; Kim, H.K.; Lim, S.S.; Chae, H.S. Stool-based miR-92a and miR-144* as noninvasive biomarkers for colorectal cancer screening. Oncology 2019, 97, 173-179. [CrossRef]

407. Li, L.; Wang, A.; Cai, M.; Tong, M.; Chen, F.; Huang, L. Identification of stool miR-135b-5p as a non-invasive diaognostic biomarker in later tumor stage of colorectal cancer. Life Sci. 2020, 260, 118417. [CrossRef] [PubMed]

408. Duran-Sanchon, S.; Moreno, L.; Auge, J.M.; Serra-Burrel, M.; Cuatrecasas, M.; Moreira, L.; Martin, A.; Serradesanferm, A.; Pozo, A.; Costa, R.; et al. Identification and validation of microRNA profiles in fecal samples for detection of colorectal cancer. Gastroenterology 2020, 158, 947-954. [CrossRef]

409. Sobhani, I.; Amiot, A.; le Baleur, Y.; Levy, M.; Auriault, M.; van Nhieu, J.T.; Delchier, J.C. Microbial dysbiosis and colon carcinogenesis: Could colon cancer be considered a bacteria-related disease? Ther. Adv. Gastroenterol. 2013, 6, 215-229. [CrossRef] [PubMed]

410. Tjalsma, H.; Boleij, A.; Marchesi, J.R.; Dutilh, B.E. A bacterial driver-passenger model for colorectal cancer: Beyond the usual suspects. Nat. Rev. Microbiol. 2012, 10, 575-582. [CrossRef]

411. Chenard, T.; Malick, M.; Dube, J.; Masse, E. The influence of blood on the human gut microbiome. BMC Microbiol. 2020, 20, 44. [CrossRef]

412. Rezasoltani, S.; Sharafkhah, M.; Asadzadeh Aghdaei, H.; Nazemalhosseini Mojarad, E.; Dabiri, H.; Akhavan Sepahi, A.; Modarressi, M.H.; Feizabadi, M.M.; Zali, M.R. Applying simple linear combination, multiple logistic and factor analysis methods for candidate fecal bacteria as novel biomarkers for early detection of adenomatous polyps and colon cancer. J. Microbiol. Methods 2018, 155, 82-88. [CrossRef]

413. Chen, J.; Pitmon, E.; Wang, K. Microbiome, inflammation and colorectal cancer. Semin. Immunol. 2017, 32, 43-53. [CrossRef]

414. Amitay, E.L.; Krilaviciute, A.; Brenner, H. Systematic review: Gut microbiota in fecal samples and detection of colorectal neoplasms. Gut Microbes 2018, 9, 293-307. [CrossRef]

415. Han, Y.W. Fusobacterium nucleatum: A commensal-turned pathogen. Curr. Opin. Microbiol. 2015, 23, 141-147. [CrossRef] [PubMed]

416. Smith Tunsjo, H.; Gundersen, G.; Rangnes, F.; Noone, J.C.; Endres, A.; Bemanian, V. Detection of Fusobacterium nucleatum in stool and colonic tissues from Norwegian colorectal cancer patients. Eur. J. Clin. Microbiol. Infect. Dis. 2019, 38, 1367-1376. [CrossRef]

417. Clos-Garcia, M.; Garcia, K.; Alonso, C.; Iruarrizaga-Lejarreta, M.; D’Amato, M.; Crespo, A.; Iglesias, A.; Cubiella, J.; Bujanda, L.; Falcon-Perez, J.M. Integrative analysis of fecal metagenomics and metabolomics in colorectal cancers. Cancers 2020, $12,1142$. [CrossRef] [PubMed]

418. Rubinstein, M.R.; Wang, X.; Liu, W.; Hao, Y.; Cai, G.; Han, Y.W. Fusobacterium nucleatum promotes colorectal carcinogenesis by modulating E-cadherin/beta-catenin signaling via its FadA adhesin. Cell Host Microbe 2013, 14, 195-206. [CrossRef] [PubMed] 
419. Suehiro, Y.; Sakai, K.; Nishioka, M.; Hashimoto, S.; Takami, T.; Higaki, S.; Shindo, Y.; Hazama, S.; Oka, M.; Nagano, H.; et al. Highly sensitive stool DNA testing of Fusobacterium nucleatum as a marker for detection of colorectal tumours in a Japanese population. Ann. Clin. Biochem. 2017, 54, 86-91. [CrossRef] [PubMed]

420. Eklöf, V.; Löfgren-Burström, A.; Zingmark, C.; Edin, S.; Larsson, P.; Karling, P.; Alexeyev, O.; Rutegård, J.; Wikberg, M.L.; Palmqvist, R. Cancer-associated fecal microbial markers in colorectal cancer detection. Int. J. Cancer 2017, 141, 2528-2536. [CrossRef] [PubMed]

421. Guo, S.; Li, L.; Xu, B.; Li, M.; Zeng, Q.; Xiao, H.; Xue, Y.; Wu, Y.; Wang, Y.; Liu, W.; et al. A simple and novel fecal biomarker for colorectal cancer: Ratio of Fusobacterium nucleatum to probiotics populations, based on their antagonistic effect. Clin. Chem. 2018, 64, 1327-1337. [CrossRef]

422. Liang, Q.; Chiu, J.; Chen, Y.; Huang, Y.; Higashimori, A.; Fang, J.; Brim, H.; Ashktorab, H.; Ng, S.C.; Man Ng, S.S.; et al. Fecal bacteria act as novel biomarkers for noninvasive diagnosis of colorectal cancer. Clin. Cancer Res. 2017, 23, 2061-2070. [CrossRef] [PubMed]

423. Wong, S.H.; Kwong, T.N.Y.; Chow, T.C.; Luk, A.K.C.; Dai, R.Z.W.; Nakatsu, G.; Lam, T.Y.T.; Zhang, L.; Wu, J.C.Y.; Chan, F.K.L.; et al. Quantitation of faecal Fusobacterium improves faecal immunochemical test in detecting advanced colorectal neoplasia. Gut 2017, 66, 1441-1448. [CrossRef] [PubMed]

424. Xie, Y.H.; Gao, Q.Y.; Cai, G.X.; Sun, X.M.; Sun, X.M.; Zou, T.H.; Chen, H.M.; Yu, S.Y.; Qiu, Y.W.; Gu, W.Q.; et al. Fecal Clostridium symbiosum for noninvasive detection of early and advanced colorectal cancer: Test and validation studies. Ebiomedicine 2017, 25, 32-40. [CrossRef]

425. Tarallo, S.; Ferrero, G.; Gallo, G.; Francavilla, A.; Clerico, G.; Luc, A.R.; Manghi, P.; Maltez Thomas, A.; Vineis, P.; Segata, N.; et al Altered fecal small RNA profiles in colorectal cancer reflect gut microbiome composition in stool samples. mSystems 2019, 4 e00289-19. [CrossRef]

426. Mjelle, R.; Sjursen, W.; Thommesen, L.; Sætrom, P.; Hofsli, E. Small RNA expression from viruses, bacteria and human miRNAs in colon cancer tissue and its association with microsatellite instability and tumor location. BMC Cancer 2019, 19, 161. [CrossRef]

427. Liu, S.; da Cunha, A.P.; Rezende, R.M.; Cialic, R.; Wei, Z.; Bry, L.; Comstock, L.E.; Gandhi, R.; Weiner, H.L. The host shapes the gut microbiota via fecal microRNA. Cell Host Microbe 2016, 19, 32-43. [CrossRef]

428. Bouvard, V.; Loomis, D.; Guyton, K.Z.; Grosse, Y.; Ghissassi, F.E.; Benbrahim-Tallaa, L.; Guha, N.; Mattock, H.; Straif, K. Carcinogenicity of consumption of red and processed meat. Lancet Oncol. 2015, 16, 1599-1600. [CrossRef]

429. Altomare, D.F.; Di Lena, M.; Porcelli, F.; Trizio, L.; Travaglio, E.; Tutino, M.; Dragonieri, S.; Memeo, V.; dr Gennaro, G. Exhaled volatile organic compounds identify patients with colorectal cancer. Br. J. Surg. 2013, 100, 144-150. [CrossRef]

430. Haick, H.; Broza, Y.Y.; Mochalski, P.; Ruzsanyi, V.; Amann, A. Assessment, origin, and implementation of breath volatile cancer markers. Chem. Soc. Rev. 2014, 43, 1423-1449. [CrossRef] [PubMed]

431. Batty, C.A.; Cauchi, M.; Lourenco, C.; Hunter, J.O.; Turner, C. Use of the analysis of the volatile faecal metabolome in screening for colorectal cancer. PLOS ONE 2015, 10, e0130301. [CrossRef]

432. McFarlane, M.; Millard, A.; Hall, H.; Savage, R.; Constantinidou, C.; Arasaradnam, R.; Nwokolo, C. Urinary volatile organic compounds and faecal microbiome profiles in colorectal cancer. Color. Dis. 2019, 21, 1259-1269. [CrossRef] [PubMed]

433. Mozdiak, E.; Wicaksono, A.N.; Covington, J.A.; Arasaradnam, R.P. Colorectal cancer and adenoma screening using urinary volatile organic compound (VOC) detection: Early results from a single-centre bowel screening population (UK BCSP). Tech. Coloproctol. 2019, 23, 343-351. [CrossRef] [PubMed]

434. Di Lena, M.; Porcelli, F.; Altomare, D.F. Volatile organic compounds as new biomarkers for colorectal cancer: A review. Color. Dis. 2016, 18, 654-663. [CrossRef] [PubMed]

435. Widlak, M.M.; Neal, M.; Daulton, E.; Thomas, C.L.; Tomkins, C.; Singh, B.; Harmston, C.; Wicaksono, A.; Evans, C.; Smith, S.; et al. Risk stratification of symptomatic patients suspected of colorectal cancer using faecal and urinary markers. Color. Dis. 2018, 20, O335-O342. [CrossRef] [PubMed]

436. Bosch, S.; Berkhout, D.J.; Ben Larbi, I.; de Meij, T.G.; de Boer, N.K. Fecal volatile organic compounds for early detection of colorectal cancer: Where are we now? J. Cancer Res. Clin. Oncol. 2019, 145, 223-234. [CrossRef]

437. Bond, A.; Greenwood, R.; Lewis, S.; Corfe, B.; Sarkar, S.; O’Toole, P.; Rooney, P.; Burkitt, M.; Hold, G.; Probert, C. Volatile organic compounds emitted from faeces as a biomarker for colorectal cancer. Aliment. Pharmacol. Ther. 2019, 49, 1005-1012. [CrossRef]

438. Nakano, Y.; Yoshimura, M.; Koga, T. Methyl mercaptan production by periodontal bacteria. Int. Dent. J. 2002, 52, 217-220. [CrossRef]

439. Ishibe, A.; Ota, M.; Takeshita, A.; Tsuboi, H.; Kizuka, S.; Oka, H.; Suwa, Y.; Suzuki, S.; Nakagawa, K.; Suwa, H.; et al. Detection of gas components as a novel diagnostic method for colorectal cancer. Ann. Gastroenterol. Surg. 2018, 2, 147-153. [CrossRef]

440. Amal, H.; Leja, M.; Funka, K.; Lasina, I.; Skapars, R.; Sivins, A.; Ancans, G.; Kikuste, I.; Vanags, A.; Tolmanis, I.; et al. Breath testing as potential colorectal cancer screening tool. Int. J. Cancer 2016, 138, 229-236. [CrossRef]

441. Wang, C.; Ke, C.; Wang, X.; Chi, C.; Guo, L.; Luo, S.; Guo, Z.; Xu, G.; Zhang, F.; Li, E. Noninvasive detection of colorectal cancer by analysis of exhaled breath. Anal. Bioanal. Chem. 2014, 406, 4757-4763. [CrossRef] [PubMed]

442. Available online: http://interactiveguidelines.esmo.org/esmo-web-app/gl_toc/index.php?GL_id=74 (accessed on 5 December 2021).

443. Dockter, A.G.; Angelos, G.C. Molecular-based alternatives for colorectal cancer screening during the COVID-19 pandemic. Surg. Technol. Int. 2020, 36, 143-147. [PubMed] 
444. Dockter, A.G.; Angelos, G.C. Stool-based DNA testing versus colon capsule endoscopy for colorectal cancer screening during the COVID-19 pandemic: A response to 'Colon capsule endoscopy: An innovative method for detecting colorectal pathology during the COVID-19 pandemic? Color. Dis. 2020, 22, 1027-1028. [CrossRef]

445. MacLeod, C.; Wilson, P.; Watson, A.J.M. Colon capsule endoscopy: An innovative method for detecting colorectal pathology during the COVID-19 pandemic? Color. Dis. 2020, 22, 621-624. [CrossRef]

446. Rex, D.K.; Adler, S.N.; Aisenberg, J.; Burch, W.C., Jr.; Carretero, C.; Chowers, Y.; Fein, S.A.; Fern, S.E.; Fernandez-Urien Sainz, I.; Fich, A.; et al. Accuracy of capsule colonoscopy in detecting colorectal polyps in a screening population. Gastroenterology 2015, 148, 948-957. [CrossRef]

447. Hong, S.N.; Kang, S.; Jang, H.J.; Wallace, M.B. Recent advance in colon capsule endoscopy: What's new? Clin. Endosc. 2018, 51, 334-343. [CrossRef] [PubMed] 